\title{
A monthly stock exchange index for Ireland, 1864-1930
}

Richard S. Grossman ${ }^{1}$, Ronan C. Lyons ${ }^{2}$, Kevin Hjortshøj O’Rourke ${ }^{3}$ \& Madalina A. Ursu ${ }^{4}$

\begin{abstract}
$^{5}$
Information on the performance of equities during the latter part of the globalized long nineteenth century is scarce, particularly for smaller European economies such as Ireland. Using a dataset of over 35,000 price-year observations from the Investor's Monthly Manual, this paper constructs new monthly Irish stock market price indices for the period 1864-1930, encompassing periods of significant economic and political turmoil in Irish history. In addition to a total market index covering all 118 equity securities issued by 94 companies, sector-specific indices are presented for railways, financial services companies, and miscellaneous industrial and retail companies. Weighted by market capitalization, nominal equity prices were largely static in the 1860 s, before increasing by almost $60 \%$ in nominal terms between 1870 and 1878 . Between 1878 and 1879, equity prices fell by one sixth in the space of a year, after which there was a secular rise in equity prices for two decades, with equity prices in 1899 twice what they had been in 1864. Between the turn of the century and the outbreak of the Great War, though, prices fell by $25 \%$, a pattern that stands in stark contrast to returns on the London exchange, which were greater during 1894-1913 than during the preceding two decades. The period from 1914 until 1929 saw a number of boom-bust cycles, concurrent with war and other political events affecting Ireland, including its independence movement. Railway equities, which had trebled between the mid-1860s and the turn of the century, fell sharply during the 1910s and 1920s. In contrast, financial equity prices - which were just $20 \%$ higher in 1920 than in 1864 - rose strongly during the 1920s. Overall, the average annual gain in equity prices over the period was just $0.9 \%$, well below levels associated with an equity premium puzzle.
\end{abstract}

Keywords: Irish stock exchange; Investor's Monthly Manual; long-run stock returns; $19^{\text {th }}$ Century; $20^{\text {th }}$ Century; Ireland

JEL Classification: E3; G12; N23; N24

\footnotetext{
${ }^{1}$ Department of Economics, Wesleyan University \& Institute for Quantitative Social Science, Harvard University

${ }^{2}$ Trinity College, Dublin \& Balliol College, Oxford - corresponding author, ronan.lyons@tcd.ie

${ }^{3}$ All Souls College, Oxford \& CEPR \& NBER \& IIIS, Trinity College Dublin

${ }^{4}$ London School of Economics

${ }^{5}$ We are extremely grateful to Michael Gallagher and John McDonagh for their outstanding research assistance. We also thank Brian Lucey, who shared his data with us; John Turner, who very graciously shared his expertise with us at several points in the project; and participants at EHES London 2013 for helpful comments. Grossman acknowledges support from the National Science Foundation (SBR 9408619). O'Rourke acknowledges financial support from the Centre for the Economics of Globalization, and from the European Research Council under the European Union's Seventh Framework Programme (FP7/2007- 2013) / ERC grant agreement no. 249546. The usual disclaimer applies.
} 


\section{Introduction}

This paper presents new monthly price indices of Irish equities for the period 1864-1930. The indices are constructed using over 35,000 equity price listings from the Investor's Monthly Manual, covering 118 separate equity securities issued by 94 firms. The data include railway, finance, and industrial/retail sectors and cover a period of over 65 years, stretching from the middle of the long $19^{\text {th }}$ century to the global financial turmoil of the interwar period.

Although long-run indices of equity performance have been compiled in recent years for a number of countries, no comparable monthly index for Ireland currently exists despite its comparatively long history of equity markets. This new index will allow more fine-grained time-series analysis of Irish stock market data, allowing researchers to study seasonality, efficiency, and correlations with other markets in a way that is not possible with annual data. It opens the possibility of conducting eventstudies of particular episodes in Irish history, similar to those conducted elsewhere (e.g. Zussman et al. 2008), and will enable a closer examination of market integration between Ireland and Great Britain (Neal 1985). In this paper, our goal is simply to provide an introduction to the new index, and outline the major features of the data. It should be noted that the focus is on equity prices; dividends are not considered here, although they accounted for a not insubstantial proportion - and possibly even a majority - of total equity returns.

This paper is structured as follows. The next section reviews the related literature, and provides an overview of the development of the Irish equities market. Subsequent sections outline the data used and the methodology employed in constructing the monthly indices, present the indices and highlight some stylised facts regarding Irish equities during this period. The final section concludes by suggesting some avenues for future research.

\section{Literature}

\section{International studies}

Generating historical stock market indices has proven something of a growth industry recently, with studies published covering the UK (Grossman 2002), US (see Goetzmann et al. 2001 and work cited therein), France (Le Bris \& Hautcoeur 2010), and Belgium (Annaert et al. 2012), among others. The construction of datasets relating to the long-run performance of equities is not new, however, with pre-World War II work including Bowley, Schwartz, and Smith (1931) and Smith and Horne (1934) in the UK and Cowles (1939) in the U.S.

Grossman (2002) presents an annual index of British equity prices and dividend yields for the period 1870-1913, using a dataset of over 2,700 companies. Ignoring the issue of attrition, Grossman's indices suggest substantial returns to holding equity during the period, with growth slightly faster during the second half of the period than the first. In annualized terms, the average annual return on equities was $6.33 \%$, of which $2.84 \%$ comprised capital appreciation. Based on this research, an index of British equity prices set to 100 in 1870 would have been 373.9 in 1913.

Goetzmann et al. (2001) construct a monthly price-weighted index based on data for over 600 firms trading on the New York Stock Exchange over the period 1815-1925. They find that over this period, the weighted annualized average growth rate in equity prices was $1.24 \%$, significantly smaller than 
dividend returns of $6 \%-8.5 \%$. Analysis of a long-run S\&P index maintained by Shiller (2013) suggests a slightly higher growth rate in equity prices over the period 1871-1930 (1.8\%).

Research on the Paris Stock Exchange shows the importance of using contemporary listings - to overcome survivorship bias, which occurs when looking only at firms that still exist - and also weighting by market capitalization, rather than using unweighted figures. Whereas previous estimates of the long-run equity price index by Arbulu (1998) suggested an annualised return of 2.33\% over the period 1854-1914, work by Le Bris \& Hautcoeur (2010) suggests the return was less than half this rate $(1.04 \%)$. As with other economies, the bulk of returns for investors in this period was through dividends, rather than capital appreciation.

In their study of the Belgian stock exchange, Annaert et al. (2012) also find relatively low returns to equities over the period 1870-1930. They also document lower volatility of equity listings before 1913 , especially in the 1860 s and 1890s, compared to the interwar period. Capital appreciation was highest in the $1920 \mathrm{~s}$ (3.2\% per annum average) and the 1890s (2.3\%). Considering Belgium's role in the Great War, it is not surprising that capital losses ran at an average of over $10 \%$ per annum during the 1910s. While they do not list a price index, their table of decadal returns suggests an annualized capital gain of $1.1 \%$ during the period $1870-1930 .^{6}$

\section{The development of an Irish equities market}

Ireland's stock exchanges date from the 1790s, when political developments following the French Revolution brought about significant government deficits, themselves requiring financing principally through debentures. As Ireland's total debt, distinct from the United Kingdom which it joined in 1801 , soared from less than $£ 2 \mathrm{~m}$ in 1792 to more than $£ 23 \mathrm{~m}$ a decade later, an association of stock brokers was formed in Dublin, initially in 1793 but more successfully in 1799 (Thomas 1986).

The development of non-government publicly traded equities was due largely to legislative changes made in the three decades prior to 1855 . Prior to this, charters had only been given to three corporations, all of a public good nature: the Grand Canal Company (1772), Bank of Ireland (1783) and the Royal Canal (1790). Other companies, following the Bubble Act of 1720, could only rely on mortgage debt or partnership for capital. The repeal of the Bubble Act in 1825 made the conferral of corporate status on firms easier. The same year saw the Irish Banking Copartnership Regulation Act, which led to the listing on the Dublin stock exchange of seven banks by 1836 , all of which were either partnerships or unlimited liability corporations.

In 1844, the freedom to incorporate was extended to all businesses and was taken up in particular by railways over the following 18 months, which were conferred limited liability due to their public good nature. By 1855, limited liability was made available to all firms, although it is worth noting that it was not taken up by existing banks. Reluctance to make the transition may be related to depositor trust: shareholders with more to lose may have been regarded as more likely to manage operations well. Reinforcing this may have been the failure of two new Dublin-listed limited liability banks in the mid-1860s (European Bank, following "Black Friday" in May 1866, and the Union Bank of Ireland in 1868).

\footnotetext{
${ }^{6}$ While the bulk of the literature analyses nominal equity prices, figures given by Annaert et al. (2012) are inflation-adjusted; no nominal statistics are presented.
} 
The failure in 1878 of the City of Glasgow bank, however, and the subsequent bankruptcy of the majority of its shareholders, appears to have severely undermined confidence in the unlimited liability banking model. The immediate legislative reaction was the Companies Act (1879), which made banks set aside, as reserve liability, funds to protect deposit-holders in case of bankruptcy. Within a few years, all banks listed on the Dublin exchange, with the exception of the Bank of Ireland, had moved to limited liability (Hickson \& Turner 2008). ${ }^{7}$

Dublin acted as the centre for trading in stocks and equities for most of the nineteenth century, although there were brokers active in other cities, particularly once the railway boom of 1845 occurred (Thomas 1986). A separate Cork stock exchange was founded in 1886, and in 1895 an exchange was established in Belfast.

\section{Research on the long-run performance of Irish equities}

Despite the relatively rich history of Irish equities from the early nineteenth century, there are to our knowledge just four works that examine their performance before the 1930s. The earliest is Whelan (1999), which examines inflation, interest rates and returns on equities in Ireland over a two-century period (1783-1998). However, for the period prior to 1934 data for the whole of the UK are used an arithmetic market capitalisation-weighted index constructed in 1997 by BZW Securities Ltd for the period 1919-1933, and share price indices published in Mitchell's British Historical Statistics for the period 1783-1919.

Although Ireland was a part of the UK from 1801, there is no strong reason to assume a priori that trends for the UK as a whole will be representative of Irish equities, particularly considering the differing economic performances of Ireland and Great Britain during the so-called "long 19th century" (Ó Gráda 1994). The pivotal event in Irish economic history during this period was the Great Famine (1845-52), which led to the death of roughly one million people and the subsequent emigration of a further million, out of a total pre-Famine population of roughly 8.5 million. This had major long-run economic consequences, facilitating an increase in per capita prosperity even though the domestic market was reduced in size.

Hickson \& Turner (2008) examine the performance of Irish equities in the pre- and post-Famine period. They calculate three monthly stock indices for the period 1825-64, based on regular monthly share prices for 8 banks and 15 railways: unweighted, weighted by paid-up capital and weighted by market-capitalisation. Due to missing information, in particular on price, they were not able to include 49 other listed firms, including 32 railways. The index presented here follows on from this work and is able to include a greater proportion of all equity listings. A preliminary index of Irish equities for the period 1825-1930, splicing together our series with the Hickson and Turner series, is presented below.

The Hickson-Turner 1825-64 indices are based on a number of sources, including newspapers, Wetenhall's The Course of the Exchange, and Registers of the Dublin Stock Exchange (for Bank of Ireland) and Ulster Banking Company's Committee and General Meeting Minute Books (for Ulster Bank). There are no data prior to 1844 on railways or Belfast-based banks. As is done in the analysis here, they only consider ordinary shares, noting that preference shares may have been regarded as

\footnotetext{
${ }^{7}$ Worth noting is the failure of the Munster Bank in 1885, due to "a combination of over-generous credit, insider lending and plain fraud" (Ó Gráda 2003). This was the only Irish bank to fail between 1867 and 1982.
} 
closer to debt than equity capital by investors (Hickson \& Turner 2008). Their series suggest that Irish equities suffered banking busts in 1830/31, 1835-41, 1847 and 1853-55 and railway busts in 1849, 1851,1853 and $1860-64$.

In related work, Hickson \& Turner (2005) construct an annual index for Irish equities, based on the Investors' Monthly Manual (IMM), for the period 1865-1913, a subset of the period analysed here. Their indices include 103 firms, 91 of which were listed on the Dublin exchange (including 27 that were additionally listed on the Cork or Belfast exchanges). The principal finding of Hickson \& Turner (2005) is that the value of Irish equities increased by about $50 \%$ between 1865 and 1897, before falling $30-40 \%$ by 1913 . They explore some reasons for this latter decline, which seems at odds with the growth in passenger revenues and deposits enjoyed by railways and banks, the two largest sectors. They suggest that the fall in the value of Irish equities may be due to a downward revision of expected future profits, as the probability of greater autonomy for Ireland, and thus of a redistribution-oriented nationalist regime, grew more likely.

The only other published research on Irish equities for the pre-1930 period is Hope \& Lucey (2007), who use daily listings from the Dublin stock exchange for three equities during the period 18501879. The focus of their paper, however, is to examine seasonality (in particular, the coefficients on daily and monthly fixed effects), rather than returns. Nonetheless, the listings underpinning their research can reveal whether there is any value to a monthly index of equities, as presented below, over an annual one (as in Hickson \& Turner 2005).

Figure 1. Share price of Great Southern \& Western railway, 1850-1879, by frequency

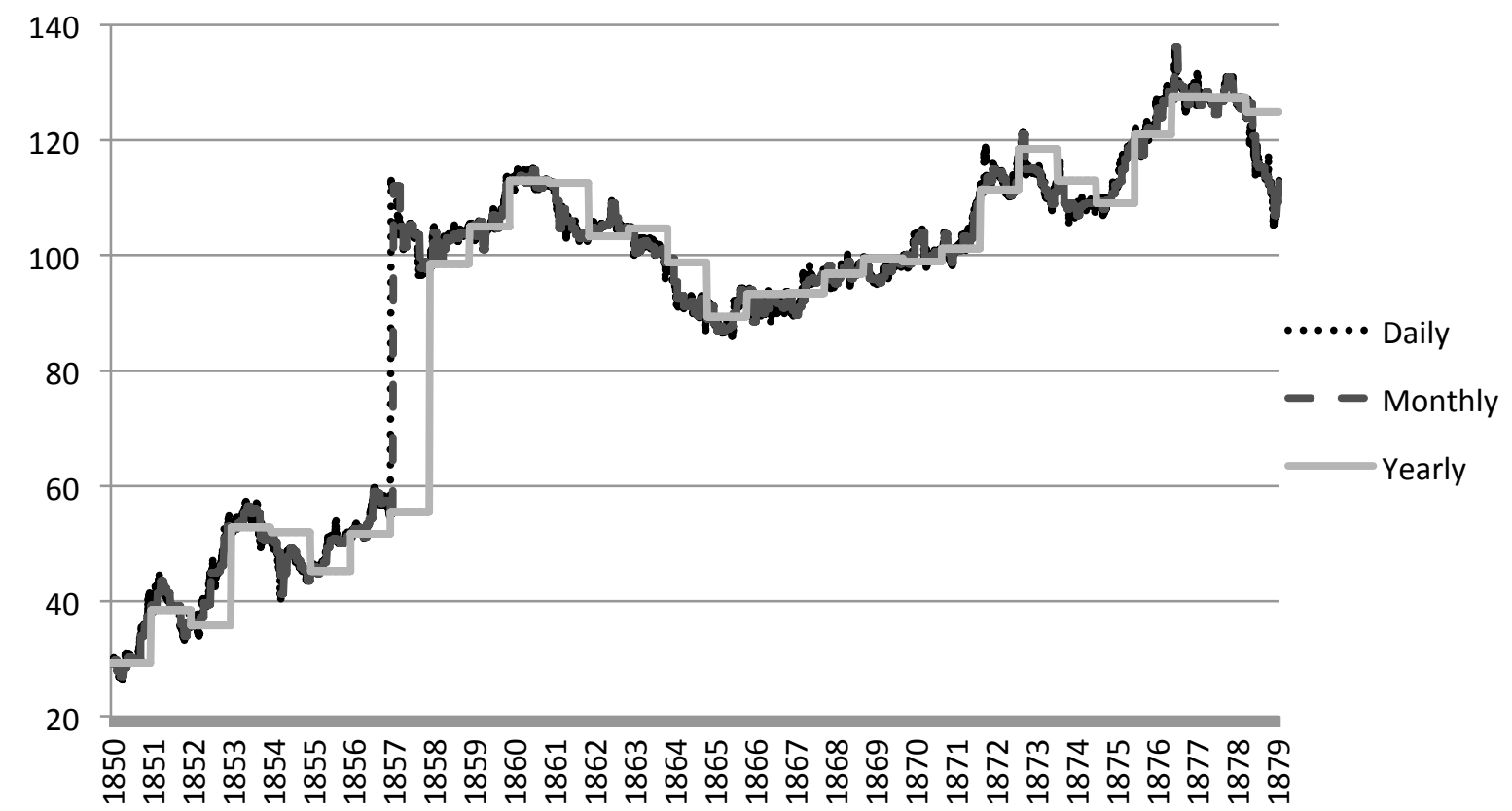

In particular, it is possible to compare variation in daily, monthly and annual price listings. This is done for Great Southern \& Western (GSW) railway in Figure $1 .{ }^{8}$ For the two decades as a whole, the correlation coefficient between the daily and monthly series is $99.4 \%$, compared to a correlation of

\footnotetext{
${ }^{8}$ The results are substantively similar if either of the other two equity listings in Hope \& Lucey (2004), Bank of Ireland or Mining Company of Ireland, are used instead.
} 
94.3\% between daily and annual. While over the two decades covered annual listings do capture most of the change in price levels, they do not capture much of the volatility. In contrast, monthly data provide a very good approximation of the volatility of daily information.

For the entire 1850-79 period, the standard deviation of the price of Bank of Ireland shares was 34.5 in daily data, 34.48 in monthly data and 33.38 in annual data. Similarly, the standard deviation of daily and monthly series for GSW and the Mining Company of Ireland ( $\mathrm{MCl}$ ) are practically indistinguishable while the standard deviation of annual data is somewhat different (27.95 and 28.02 compared to 29.54 for GSW, and 6.50 and 6.50 , compared to 6.18 for $\mathrm{MCl}$ ).

There are thus three major advantages to the series presented here over the annual series presented in Hickson and Turner (2005). First, the monthly indices presented here will add significantly to our understanding of the volatility of equity prices for the pre-1913 period. Second, by extending our index back to 1864, we can splice them onto the Hickson-Turner (2008) monthly index. Finally, our indices cover the 1914-1930 period, which is pivotal in Irish history, spanning the Great War, Ireland's 1916 Rising, the subsequent War of Independence, partition and the Civil War, as well as the period running up to the Great Depression.

\section{Data and Methodology}

The aim of this study is to produce a nominal equity price index, comparable with a growing literature in the area. The data source used is the Investor's Monthly Manual (IMM), published monthly from October 1864 to June 1930, which is also the source used by Grossman (2002), Smith \& Horne (1934), and Hickson \& Turner (2005). The IMM reported details for securities on London and provincial exchanges within the United Kingdom, of which Ireland was a part until 1922. Four pieces of information are collected on a monthly basis for each listing: the latest price traded in the month $^{9}$; the number of shares outstanding (or amount of paid-up capital for stock listings); the amount per share (or nominal value of the share); and the par amount (i.e., paid-in capital per share, typically at initial listing date). ${ }^{10}$ On a semi-annual basis, information is also included on where the listing is primarily traded. Listings are also arranged by sector, enabling a split by industry.

Share listings are comparable to modern equities, with a certain number of tradable shares and the price representing the value of each. Stock listings were effectively share companies where, instead of the share price being traded, the price was effectively an index of the value of the company. Typically, stock listings had a par value of 100 , so a listing with a price of 90 , a par of 100 and a capital subscribed of $£ 200,000$ would be treated as having a market capitalization of $£ 180,000$. All railways were stock listings, while for other listings, the vast majority were shares, rather than stock, with the following exceptions: Bank of Ireland, City of Dublin Steam (throughout), Alliance \& Dublin Consumers Gas (which converted from stock to share in 1915 and back in 1923), Connorree (which converted from share to stock in 1871), and Grand Canal (which converted from stock to share in 1895).

\footnotetext{
9 "Latest price" was preferred over "last business done", as the latter refers to the price regardless of when traded, while the former refers to prices within that month and is therefore more accurate.

${ }^{10}$ Shares during this period would have been listed with a "nominal amount," of which only a portion might be paid in, the remainder potentially callable at the discretion of the directors (Grossman \& Imai 2013).
} 


\section{Listings included}

For the purpose of this research, those IMM equity listings described as chiefly traded in Irish cities (Dublin, Cork and Belfast) were classed as Irish and included in the indices. We consider all Irish listings, both north and south of the border which emerged after partition in 1922. Each company is listed in Appendix 1, together with information including sector, cities where the equity was primarily traded, and any additional listings (see below). Companies traded in Irish cities but without significant Irish activities were excluded. ${ }^{11}$ In total, there were 94 distinct Irish companies included in the IMM throughout the entire period to 1930.

In addition to these, it is worth noting that Arthur Guinness \& Co. is not included in the core index, as it was listed solely on the London exchange. ${ }^{12}$ Its operations, however, were solely in Dublin until the mid-1930s, although as early as the 1840s England accounted for more than half of its sales by volume or value, a proportion that fluctuated during the $19^{\text {th }}$ century (Lynch \& Vaizey 1960). As outlined in Appendix 1, a more practical reason for excluding Guinness from the core index is its large size: by the 1920s, it would have constituted roughly two thirds of Irish market capitalization, meaning that movements in its share price would dominate the index.

\section{Multiple listings and preference shares}

A number of companies over the period had multiple listings. In some cases, this resulted from merger and acquisition in the railway industry. For example, Great Northern of Ireland took over the Londonderry \& Enniskillen railway in 1882 but retained its separate listing. In other cases, additional listings resulted merely from the issue of new share capital, such as the Belfast Banking Company's "New" listing, also in the 1880s. All such extra listings are included. In total, the 94 companies included had 119 listings. In our unweighted listings, we include all shares separately, potentially overweighting firms with multiple issues.

A number of companies, in particular railways, also issued preference shares, e.g. Dublin \& Drogheda, which had in addition to its ordinary shares three additional listings: $4 \%$ perpetual, $4.5 \%$ guaranteed preference and 5\% preference shares. Given that this type of listing specified a return, we view these as more akin to debt than equity and so they have been excluded from the principal indices presented here; a comparison of indices with and without preference listings is presented in Appendix $1 .^{13}$ There were 71 listings of a preference nature or some specified return, the vast majority (53) relating to railway companies.

\section{Overview of listings included}

Of a total of 224 candidate listings during the period, just under half (105) were excluded, because the listing was preference or similar (71 listings), the company was not Irish-focused (22), or because

\footnotetext{
${ }^{11}$ This group comprised five companies: Cape Copper Ltd (mining; 2 listings); Dorman, Long \& Co (steel; 3 listings); Hancock Wm. \& Co. (brewing; 4 listings); National Bank of Liverpool; Parker's Burslem Brewery; and Dunlop Pneumatic Tyre/Dunlop Rubber (9 listings).

${ }^{12}$ A comparison of the market capitalization and equity price performance of Guinness and all other Irish listings is given in Appendix 1.

${ }^{13}$ This distinguishes the work here from the annual analysis by Hickson \& Turner over the period 1865-1913, who included both preference and debentures shares in their indices of the Irish stock market. Three companies had only preference listings during the period analysed: the Waterford, Dungarvan \& Lismore railway; the "Irish Times" newspaper; and Robinson \& Cleaver, a Belfast retail store.
} 
the listing was not active in the period, despite inclusion in the IMM (12). ${ }^{14}$ Figure 2 outlines the breakdown by sector of the 118 valid Irish equity listings over the period 1864-1930. In this figure and subsequently, vertical black lines represent the 1873 financial crisis, the supposed end of the Long Depression in 1896 and the signing of the Treaty leading to the establishment of the Irish Free State (December 1921), while the shaded area represents the Great War. There appear to have been two booms in the number of new listings (the mid-1860s and the early 1880s) and the number of listings peaked in the early 1880s, at almost 70, before a steady decline, with fewer than 20 listings by the time the period finishes in 1930. For the period as a whole, the railway (32 listings) and finance (26 listings) sectors comprise just under half of all listings.

Figure 2. Number of listings by sector, 1864-1930

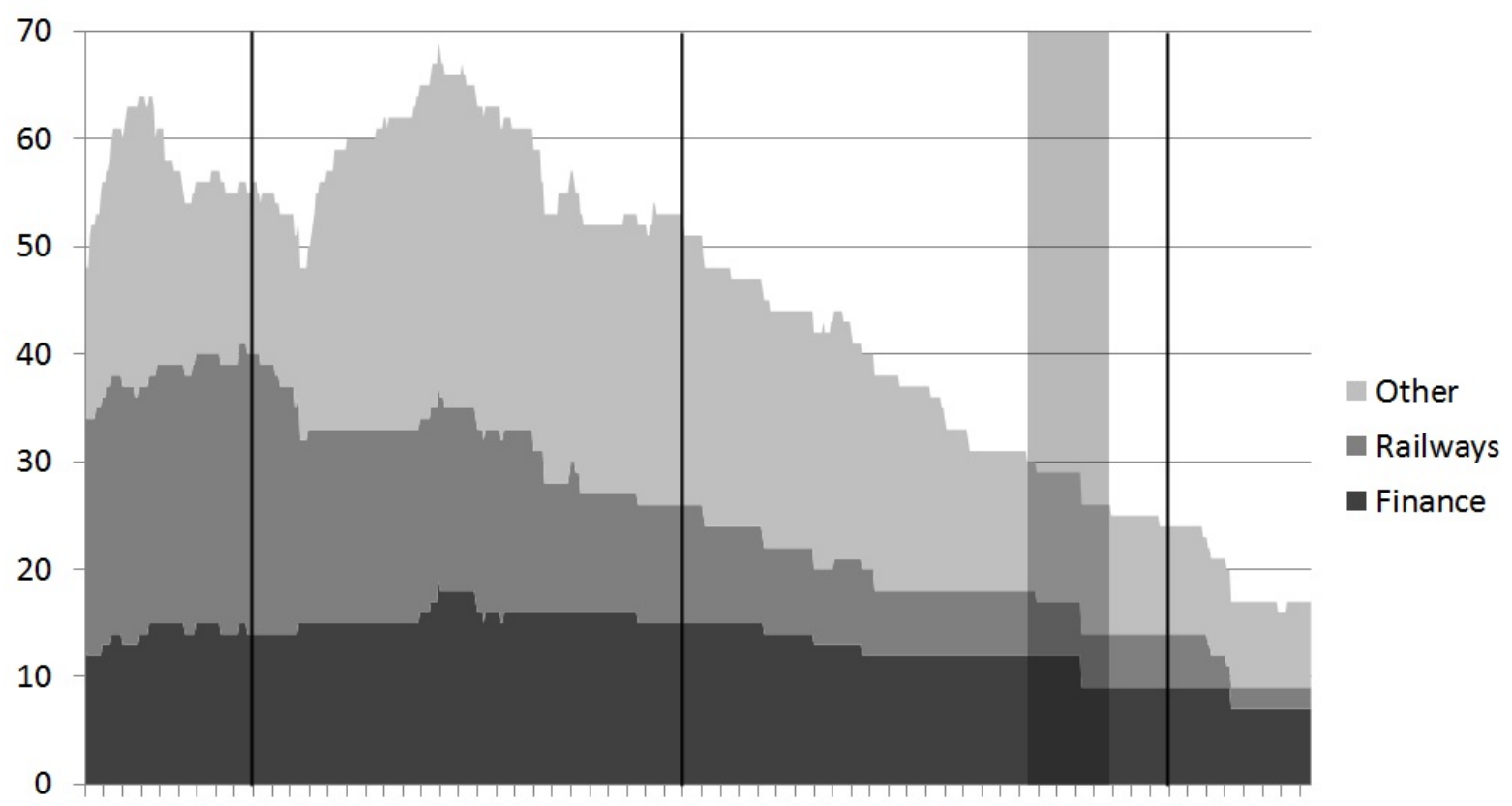

范说:

\section{Irish companies not in the IMM}

The IMM was not an exhaustive listing of all equities traded in Ireland. Comparisons were made between the Irish-based equities included in the IMM and available listings of exchanges in Cork (1898), Belfast (1897) and Dublin (1869, 1899 and 1929). For the late 1890s, roughly one third of Irish listings were included in the IMM: there were 45 Irish-based listings included, compared to 42 Belfast listings not included, 39 from Dublin and 7 from Cork.

However, the market capitalisation of the IMM-based listings in 1897-99 ( $£ 46.7 \mathrm{~m}$ on average) was significantly larger than the combined capitalisation of those not included in the IMM (estimated at $£ 14.9 \mathrm{~m})$. The bulk of the market capitalisation not included is from Belfast-based firms ( $f 11.7 \mathrm{~m})$, for which no detailed listings survive to reconstruct monthly indices. In relation to Dublin, for which listings do survive, there is evidence that the IMM became less comprehensive over time: it included

\footnotetext{
${ }^{14}$ Listings excluded as inactive, since key price information was missing, were: Banbridge Junction; Belfast, Holywood \& Bangor; Londonderry \& Coleraine; Newry \& Armagh; British \& Irish Sugar Refining; and Cork Harbour, Docks \& Warehouse.
} 
37 of 39 Dublin listings in 1869, 44 of 83 in 1899 and 18 out of 62 by 1929 . Nonetheless, even by 1929 , the included listings accounted for $89.9 \%$ of estimated market capitalisation.

Publicly listed companies are, of course, only a small subset of the complete set of corporations. If equities are to give some indication of broader economic activity, it is important to understand how representative the companies included in this index are of all corporate activity during the period. Thomas (1986) reports that, following the 1844 Companies Act, 2,854 companies were founded in Ireland in the second half of $1800 \mathrm{~s}$, with a total nominal share capital of $1109.6 \mathrm{~m}$ and called up capital of roughly $f 55 \mathrm{~m}$ - by 1906 , roughly half $(1,387)$ had survived. The nominal share capital (including preference issues) of the companies included in this study totals $£ 45 \mathrm{~m}$, indicating that although small in number, the businesses listed in the IMM represent a significant proportion of corporate economic activity on the island of Ireland in the period covered.

Overall, weighted indices based on the IMM directory will accurately capture trends in equity wealth for Irish-based equities during the period 1864-1930. Unweighted indices will be less representative, particularly later in the period when our IMM-based index excludes a greater proportion of Dublin listings, but for the two principal industries listed on stock exchanges in this period, railways and banking, all major companies are represented. Both indices will capture trends in the largest and most liquid corporations.

\section{Market capitalization}

Market capitalization was calculated by multiplying the number of shares by their price, for share listings, and by multiplying the ratio of price to par by the subscribed capital, for stock listings. Figure 3 shows the market capitalization of Irish equities, broken down into three main sectors, from October 1864 to July 1930. The market capitalization rose rapidly from $f 25.4 \mathrm{~m}$ in 1864 to just under $\mathrm{f43 \textrm {m }}$ in 1878. The following 18 months saw a sharp fall, with the following partial recovery undone again by a sharp fall in market capitalization late 1885 and early 1886 . The decade to mid-1896, though, saw aggregate market capitalization increase from $f 33.8 \mathrm{~m}$ to $£ 48.8 \mathrm{~m}$. At that point, railways and financial equities were worth roughly similar amounts ( $£ 20.1 \mathrm{~m}$ and $£ 20.7 \mathrm{~m}$ respectively), while other equities were worth $f 7.9 \mathrm{~m}$.

Between 1896 and 1914, there was a steady and substantial decline in the value of Irish equities, with listings worth a total of $£ 31.6 \mathrm{~m}$ by the outbreak of the Great War. Railways contributed almost half of the fall in value in that period ( $f 8.9 \mathrm{~m}$ out of $f 18 \mathrm{~m})$. The period from 1914 to January 1927 saw a further decline in market capitalization, from $f 31.6 \mathrm{~m}$ to $\mathrm{f} 19.3 \mathrm{~m}$, with railways comprising $70 \%$ of the fall during this period. Between 1927 and the end of the sample, mid-1930, market capitalization increased to $f 23 \mathrm{~m}$, with financial listings accounting for $88 \%$ of the growth. Overall, market capitalization was $11 \%$ lower in 1930 than it had been in 1864 .

Table 1 shows the percentage of market capitalization due to each of the three main sectors, at fiveyear intervals, from 1865 to 1930 . The final decade in particular saw a sharp decline in the importance of rail, with the banking sector comprising three quarters of market capitalization by 1930, compared to roughly half for most of the period prior to 1920. This was due to a combination of the rapid decline in the value of railway listings in the 1920s (driven in part by consolidation in the sector) and growth of $35 \%$ in the market capitalization of financial listings in the same period. 
Figure 3. Market capitalization by sector ( $($ 000), 1864-1930

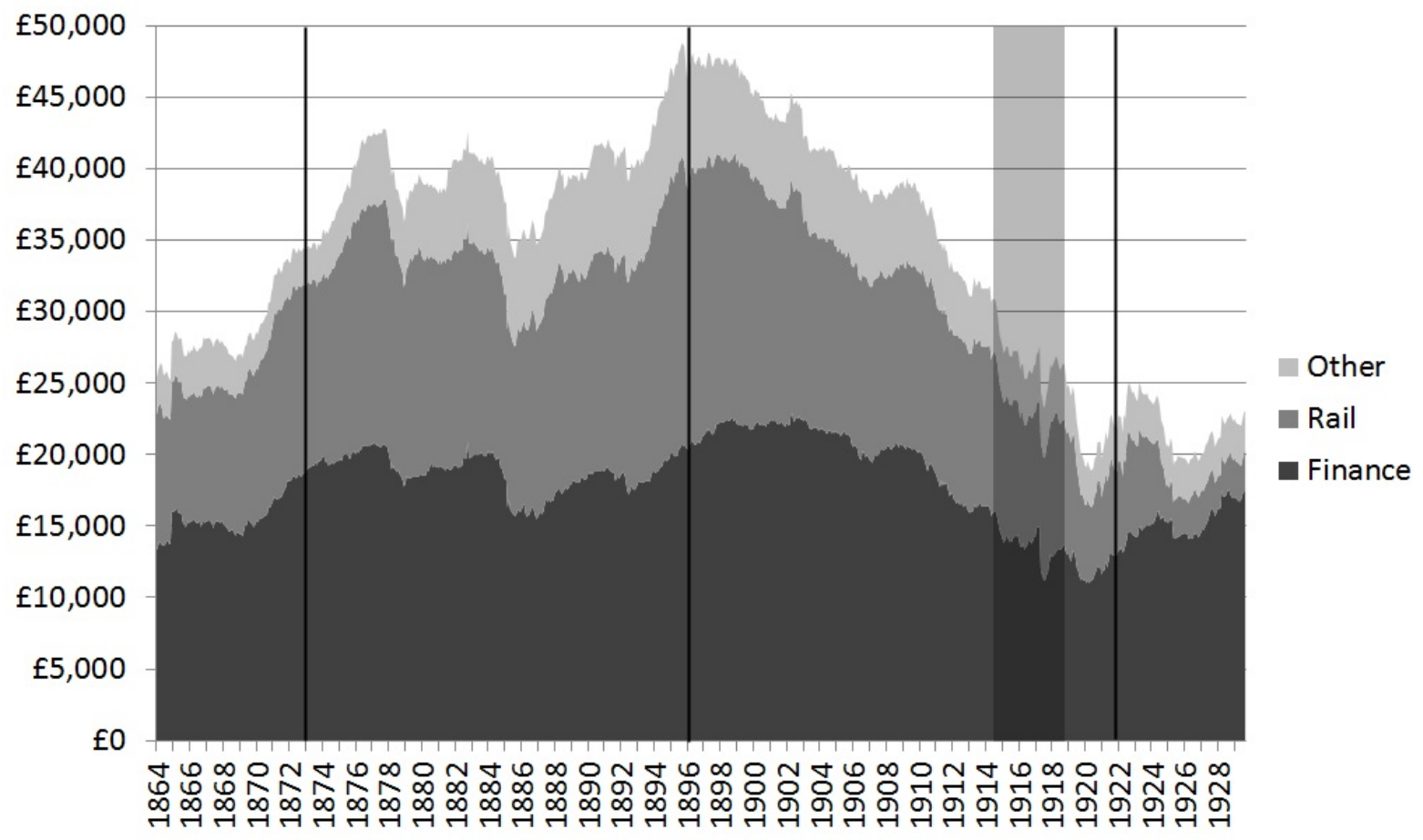

Table 1. Market capitalization, by sector (\% of total), five-year intervals

\begin{tabular}{rrrr}
\hline & Finance & \multicolumn{1}{l}{ Rail } & \multicolumn{1}{l}{ Other } \\
\hline $\mathbf{1 8 6 5}$ & $52.3 \%$ & $36.7 \%$ & $11.0 \%$ \\
$\mathbf{1 8 7 0}$ & $53.9 \%$ & $37.0 \%$ & $9.1 \%$ \\
$\mathbf{1 8 7 5}$ & $54.7 \%$ & $36.5 \%$ & $8.8 \%$ \\
$\mathbf{1 8 8 0}$ & $47.8 \%$ & $39.9 \%$ & $12.3 \%$ \\
$\mathbf{1 8 8 5}$ & $49.6 \%$ & $35.1 \%$ & $15.4 \%$ \\
$\mathbf{1 8 9 0}$ & $45.8 \%$ & $37.2 \%$ & $17.0 \%$ \\
$\mathbf{1 8 9 5}$ & $42.7 \%$ & $41.1 \%$ & $16.3 \%$ \\
$\mathbf{1 9 0 0}$ & $47.2 \%$ & $39.5 \%$ & $13.3 \%$ \\
$\mathbf{1 9 0 5}$ & $52.2 \%$ & $32.6 \%$ & $15.2 \%$ \\
$\mathbf{1 9 1 0}$ & $52.3 \%$ & $33.3 \%$ & $14.4 \%$ \\
$\mathbf{1 9 1 5}$ & $51.2 \%$ & $35.6 \%$ & $13.2 \%$ \\
$\mathbf{1 9 2 0}$ & $53.7 \%$ & $33.3 \%$ & $13.0 \%$ \\
$\mathbf{1 9 2 5}$ & $65.3 \%$ & $22.3 \%$ & $12.4 \%$ \\
$\mathbf{1 9 3 0}$ & $75.6 \%$ & $12.1 \%$ & $12.3 \%$ \\
\hline
\end{tabular}

\section{Construction of price indices}

We constructed both weighted and unweighted nominal monthly indices of equity prices for Ireland, for the period 1864-1930. This is done for the stock market as a whole, as well as for three industry groupings: railways, banking and all other industries (which includes brewing, textiles, retail and mining). For valid listings, the latest price for each month was taken. This gave a price change for listing $i$ at time $t, \delta \mathrm{p}_{\mathrm{it}}=\mathrm{p}_{\mathrm{it}} / \mathrm{p}_{\mathrm{i}, \mathrm{t}-1}$. 
- Unweighted: The simplest index of changes in equity prices is an unweighted average of the changes in listed price. In month $t$, the unweighted price index changes by $\delta P^{4}{ }_{t}=1 / n \Sigma_{i} \delta p_{i t}$, where $n$ refers to the total number of valid price changes in that month.

- Weighted: For weighted indices, the change in price $\delta p_{i t}$ was weighted by that listing's share in overall market capitalization in the denominator period, $\rho_{i, t-1}$.

Where no business was done for a month, the previous price was used for market capitalization estimations and it is assumed that the price did not change. Less frequently, information on the number of shares was missing. This typically occurred just after a new listing commenced and so the number of shares was taken from the subsequent month.

\section{Par \& other accounting changes}

There were 61 par changes in the dataset, of which the majority (36) relate to changes in the financial sector. Thirteen of these coincide with changes in the number of shares, while most of the remainder date from the early 1880s, when Irish banks converted to limited liability. Of par changes outside the financial sector, two companies during the 1870s account for eleven, while a number relate to changes in share issue or stock subscribed. While the technicalities of specific accounting practices are not known, many par changes where share capital is fixed appear to relate to a rapidly growing listing and do not have an impact on market capitalization. In order to prevent any biases from these changes, though, for months where par changes for a particular listing occurred, that listing was dropped from the sample.

On a number of occasions, there were discrepancies in relation to the timing of a change in the structure of listing, between when a par or paid amount was changed and the latest price. Where this occurred, the latest price was taken as a more accurate source for the timing of a change.

\section{Indices and Stylised facts}

\section{Overview}

The full monthly indices, both weighted and unweighted, are given in Appendix 2. An overview is given in Table 2, which shows the price index for the final month of five-year intervals from 1865 to 1930, with the first month (October 1864) set as the base for the index. Table 3 shows the percentage change in equity prices, by sector and five-year interval, for the same period.

Table 2. December weighted price index of Irish equities, by sector, five-year intervals (Oct 1864=100)

\begin{tabular}{rrrrr}
\hline \multicolumn{1}{l}{ All } & Finance & Railways & \multicolumn{1}{l}{ Other } \\
\hline $\mathbf{1 8 6 5}$ & 102.4 & 102.3 & 102.7 & 102.1 \\
$\mathbf{1 8 7 0}$ & 111.0 & 102.8 & 125.6 & 104.5 \\
$\mathbf{1 8 7 5}$ & 144.6 & 126.7 & 172.6 & 141.1 \\
$\mathbf{1 8 8 0}$ & 144.0 & 121.3 & 173.5 & 157.4 \\
$\mathbf{1 8 8 5}$ & 132.2 & 113.7 & 144.6 & 159.6 \\
$\mathbf{1 8 9 0}$ & 161.3 & 133.7 & 187.1 & 182.0 \\
$\mathbf{1 8 9 5}$ & 190.2 & 146.2 & 238.0 & 212.6 \\
$\mathbf{1 9 0 0}$ & 194.7 & 164.0 & 219.0 & 207.6 \\
$\mathbf{1 9 0 5}$ & 179.2 & 158.8 & 181.7 & 198.5 \\
\hline
\end{tabular}




\begin{tabular}{rrrrr}
\hline $\mathbf{1 9 1 0}$ & 180.4 & 154.7 & 184.5 & 210.9 \\
$\mathbf{1 9 1 5}$ & 136.5 & 112.2 & 143.4 & 167.3 \\
$\mathbf{1 9 2 0}$ & 122.0 & 118.2 & 88.3 & 179.1 \\
$\mathbf{1 9 2 5}$ & 154.6 & 174.9 & 54.4 & 226.2 \\
1930 & 183.6 & 203.2 & 60.3 & 266.2 \\
\hline
\end{tabular}

Table 3. Change in weighted Irish equity prices, by sector and five-year interval, 1865-1930

\begin{tabular}{lrrrr}
\hline & \multicolumn{1}{c}{ All } & Finance & Railways & \multicolumn{1}{c}{ Other } \\
\hline $\mathbf{1 8 6 5 - 1 8 7 0}$ & $8 \%$ & $0 \%$ & $22 \%$ & $2 \%$ \\
$\mathbf{1 8 7 0 - 1 8 7 5}$ & $30 \%$ & $23 \%$ & $37 \%$ & $35 \%$ \\
$\mathbf{1 8 7 5 - 1 8 8 0}$ & $0 \%$ & $-4 \%$ & $1 \%$ & $12 \%$ \\
$\mathbf{1 8 8 0 - 1 8 8 5}$ & $-8 \%$ & $-6 \%$ & $-17 \%$ & $1 \%$ \\
\hline $\mathbf{1 8 8 5}-1890$ & $22 \%$ & $18 \%$ & $29 \%$ & $14 \%$ \\
$\mathbf{1 8 9 0 - 1 8 9 5}$ & $18 \%$ & $9 \%$ & $27 \%$ & $17 \%$ \\
$\mathbf{1 8 9 5 - 1 9 0 0}$ & $2 \%$ & $12 \%$ & $-8 \%$ & $-2 \%$ \\
$\mathbf{1 9 0 0 - 1 9 0 5}$ & $-8 \%$ & $-3 \%$ & $-17 \%$ & $-4 \%$ \\
$\mathbf{1 9 0 5 - 1 9 1 0}$ & $1 \%$ & $-3 \%$ & $2 \%$ & $6 \%$ \\
$\mathbf{1 9 1 0 - 1 9 1 5}$ & $-24 \%$ & $-27 \%$ & $-22 \%$ & $-21 \%$ \\
$\mathbf{1 9 1 5 - 1 9 2 0}$ & $-11 \%$ & $5 \%$ & $-38 \%$ & $7 \%$ \\
$\mathbf{1 9 2 0 - 1 9 2 5}$ & $27 \%$ & $48 \%$ & $-38 \%$ & $26 \%$ \\
$\mathbf{1 9 2 5 - 1 9 3 0}$ & $19 \%$ & $16 \%$ & $11 \%$ & $18 \%$ \\
\hline
\end{tabular}

Figure 4. Irish equity price indices, weighted and unweighted (Oct 1864=100)

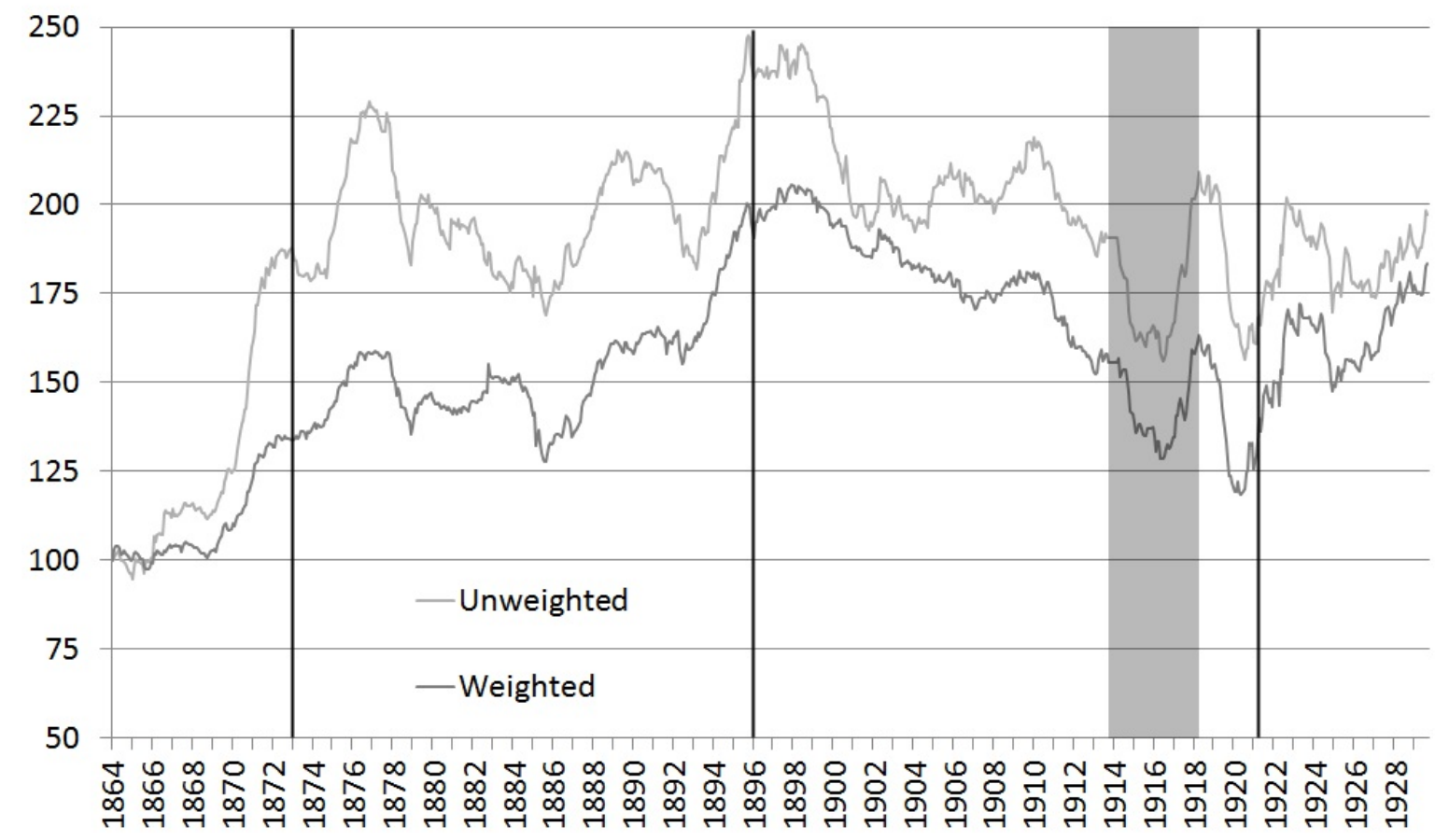


A graph of the monthly price indices, both weighted and unweighted, for all Irish stock exchange listings in the IMM is shown in Figure 4. There is significant comovement across the two series. However, there are important differences over time. The unweighted index saw significantly larger gains in the period 1864-1877: $129 \%$, compared to $58 \%$ for the weighted index. Larger companies performed significantly better over the subsequent two decades, however, with the weighted price index growing $26 \% 1877-1896$, compared to $8 \%$ in the unweighted price. The following two decades saw roughly similar falls in both indices (35\% unweighted and 33\% weighted, by 1916). The final 15 years saw a somewhat better performance in the weighted index: growth of $36 \%$ compared to $23 \%$ in the unweighted price index. The relative performance of large and small companies is a topic worthy of more in-depth research.

Figures 5 and 6 show the weighted and unweighted indices for each of three sectors: railways, financial listings, and all other listings. The peak of equity prices in the late 1890s indicated by the overall indices stems from the performance of railways, which peaked at this time. The financial and other sectors also exhibited a poor performance measured by price between the late $1890 \mathrm{~s}$ and the outbreak of the Great War. These two sectors, however, saw relatively significant growth in equity prices during the final decade analysed. Unweighted indices show a particularly rapid growth in the prices of railway shares during the early part of the sample.

\section{Comparison with Hickson-Turner}

It is possible to compare the newly constructed monthly price indices (GLORU) with the existing Hickson-Turner annual price indices (HT). This is done for all equity listings in Figure 7, using yearend data from the indices outlined above. The two indices perform relatively similarly until the late 1800 s, peaking around 1897-8. However, the decline in the Hickson-Turner index by 1913 is more pronounced, falling $48 \%$ compared to $24 \%$.

Figure 5. Weighted equity price indices, by sector (Oct 1864=100)

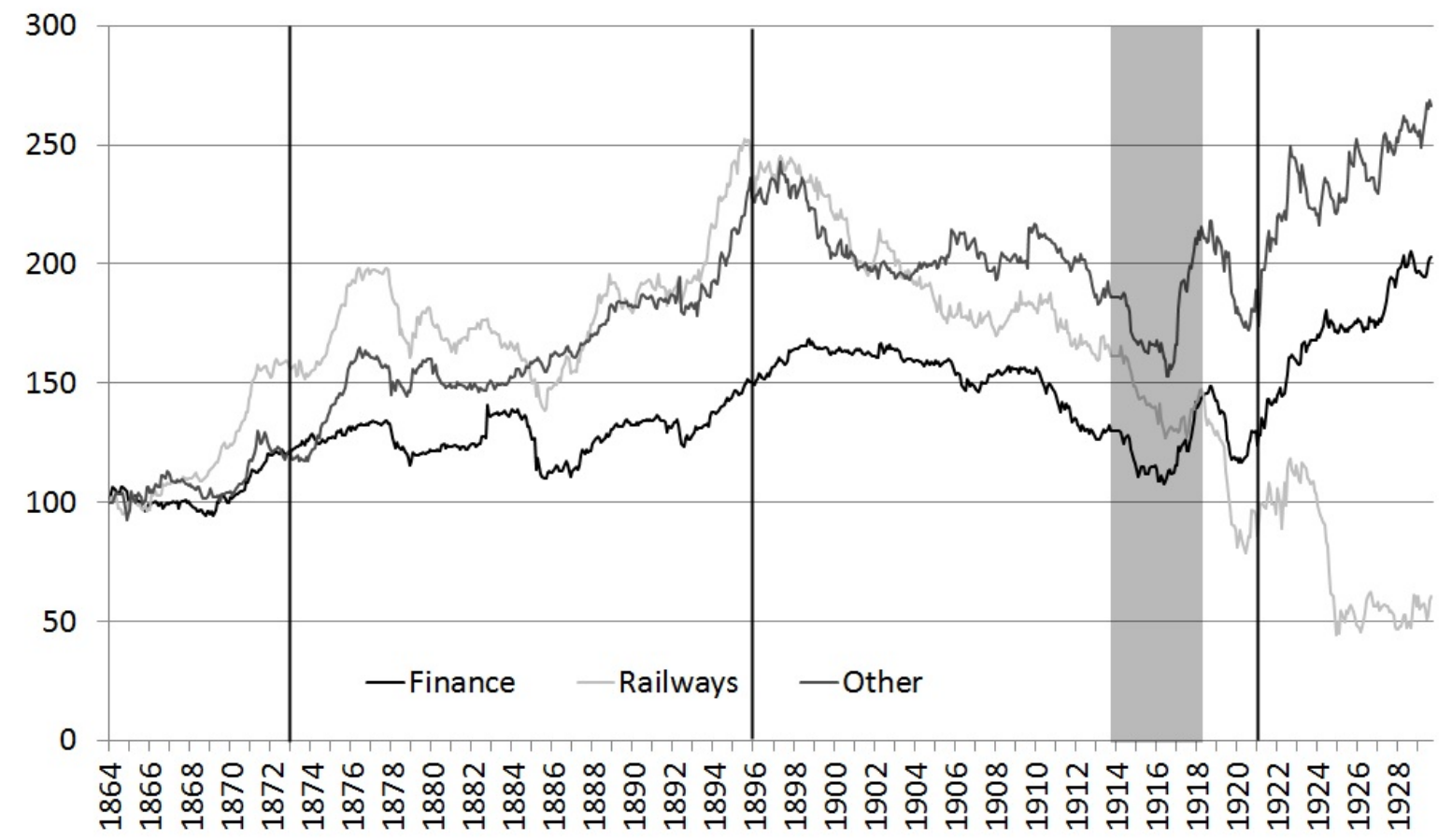


Figure 6. Unweighted equity price indices, by sector (Oct 1864=100)

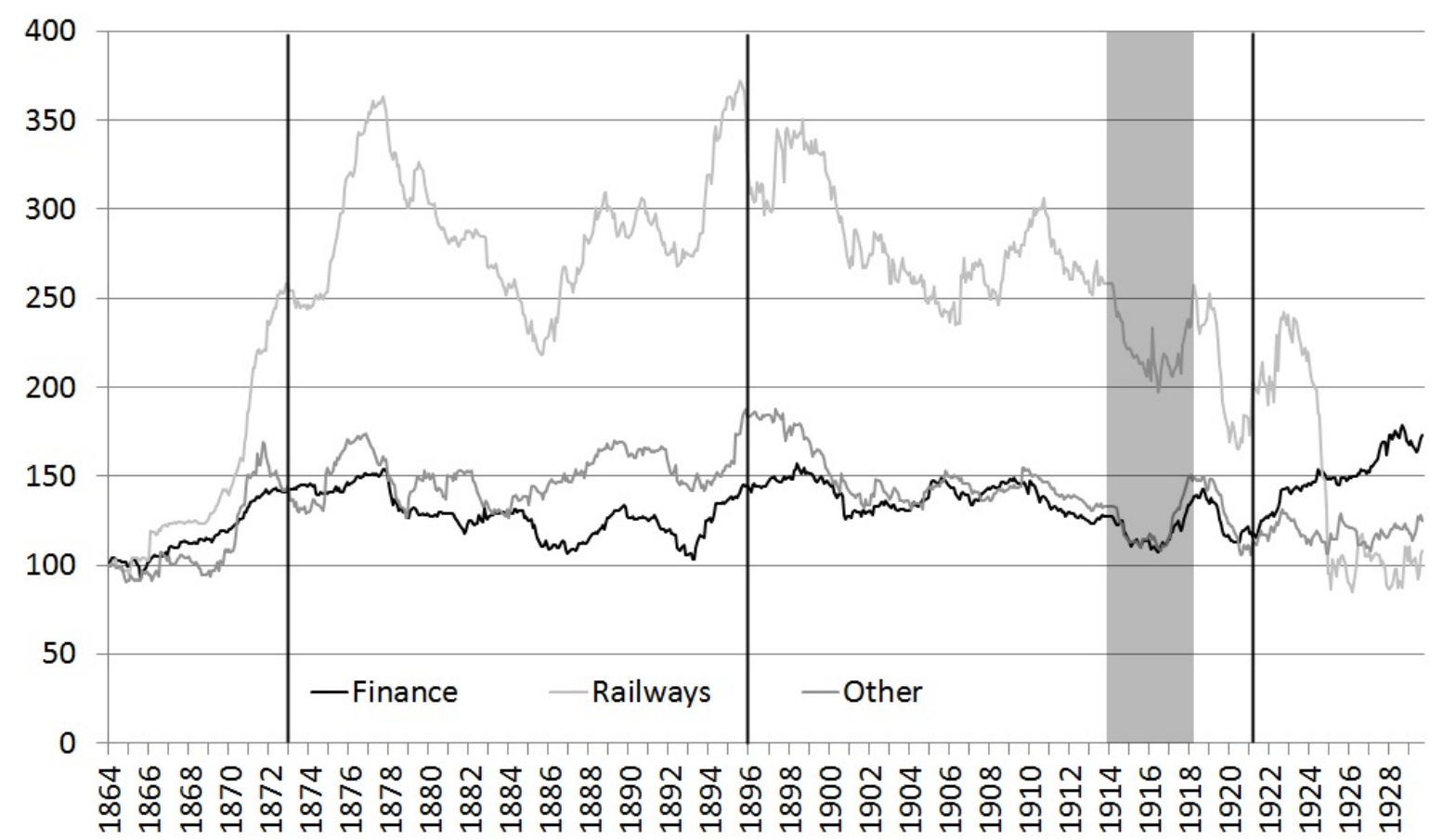

Figure 7. Annual equity prices, compared to Hickson-Turner $(1880=100)$

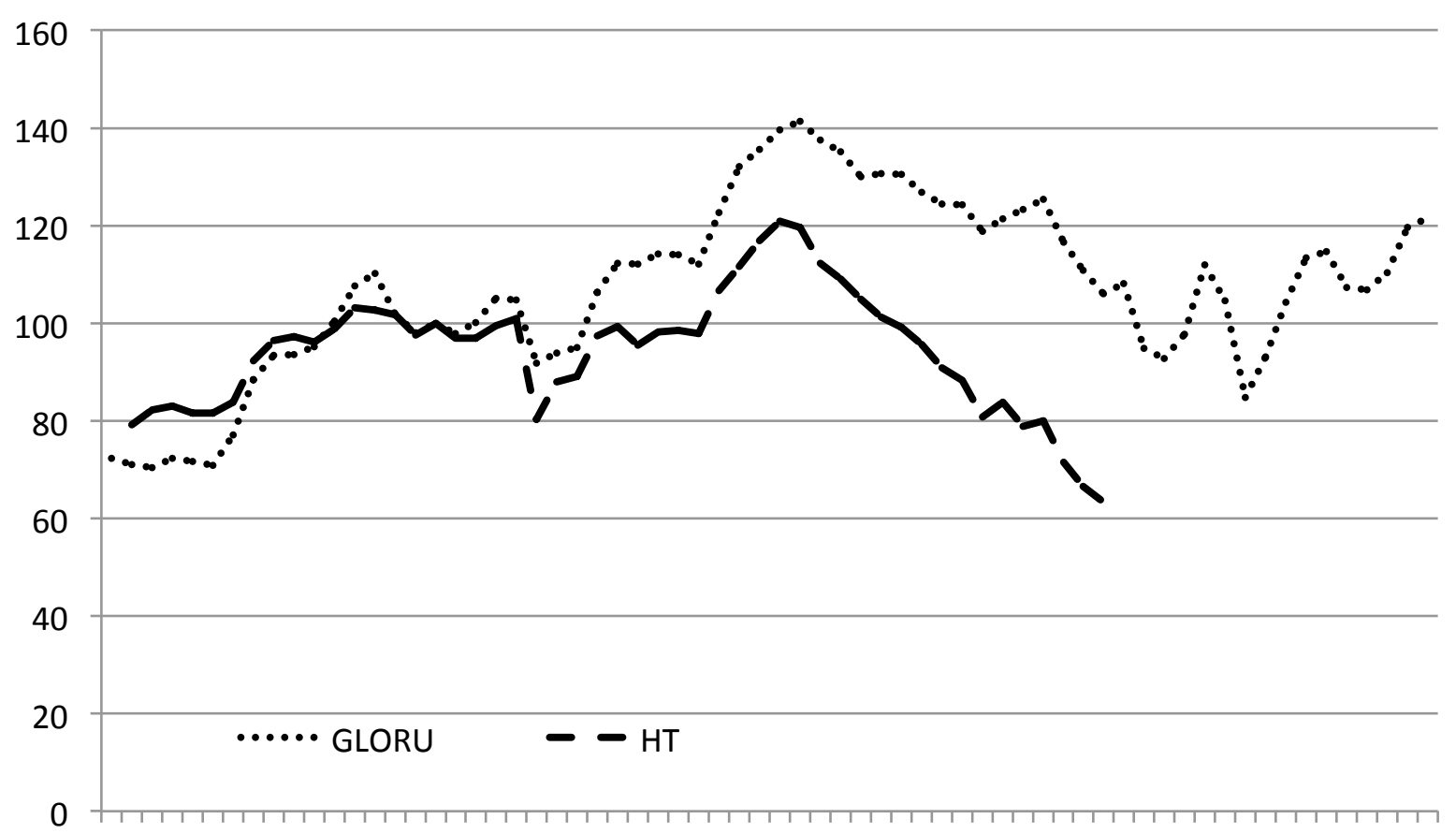

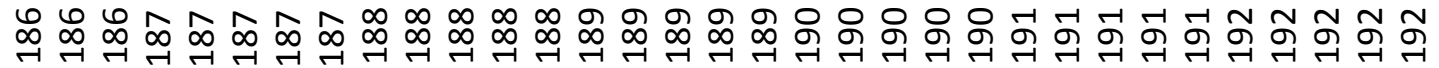


(a) Railways

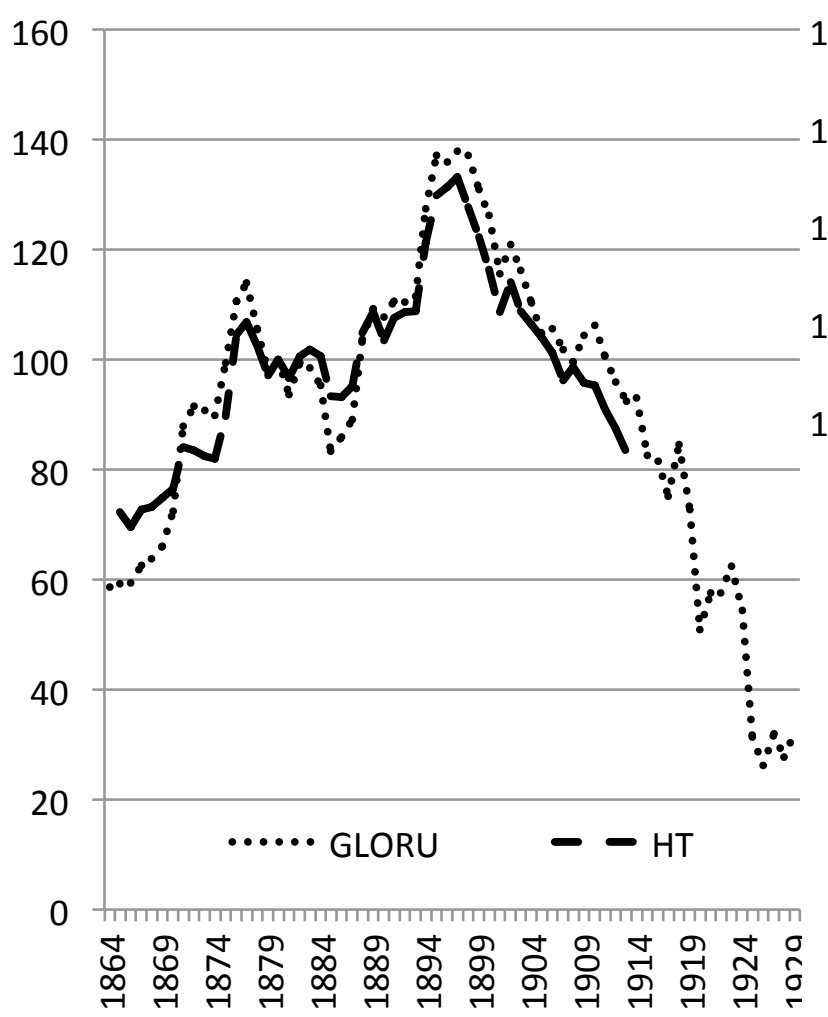

(b) Financials

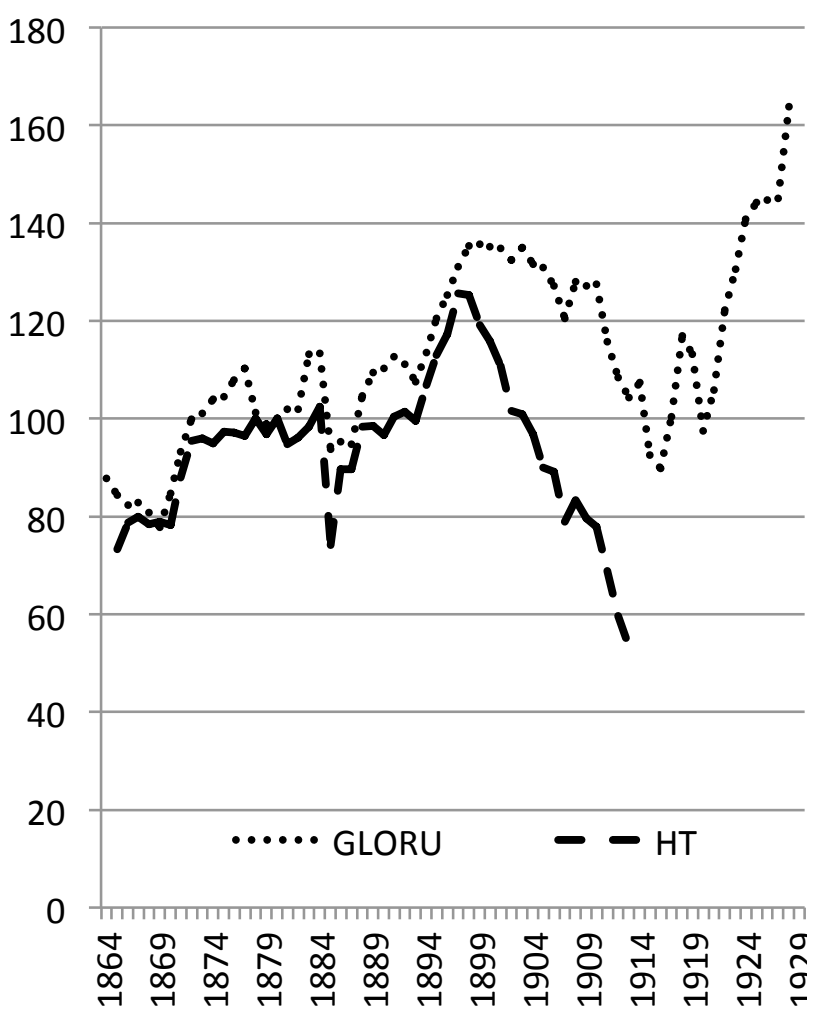

Figure 8 looks at the performance of equity prices for both railways and the financial sector. Despite the inclusion in Hickson-Turner of preference listings, this does not appear to have a substantive effect on an index of equity prices for the railway sector, with a fall in prices of roughly $35 \%$ in both series.

The difference between the two estimates appears due instead to equity prices for financial listings. The series presented here - based on market-cap weights that update every month - declines $23 \%$ between 1898 and 1913, compared to a decline of 57\% in the Hickson-Turner series. No individual bank share declines by that proportion in that period, so we are confident that the series presented here is accurate.

\section{Changes in equity prices}

Figure 9 shows the annual change in prices for Irish equities according to both the weighted and unweighted indices. Of note is the relative scarcity of price declines before 1878 and the relative lack of price increases in the following decade. Similarly, the strong price growth in the mid-1890s was followed by a prolonged period of scarcely any sustained growth in equity prices, until the late 1910s. The final decade under analysis shows significant volatility in prices, with the rapid growth of the end of the war followed by a sharp decline around the time of Ireland's War of Independence, itself followed by substantial growth in the mid-1920s. The end of the sample finishes with equity prices rising moderately. 
Figure 9. Year-on-year change in equity prices, by weighting method (all equities)

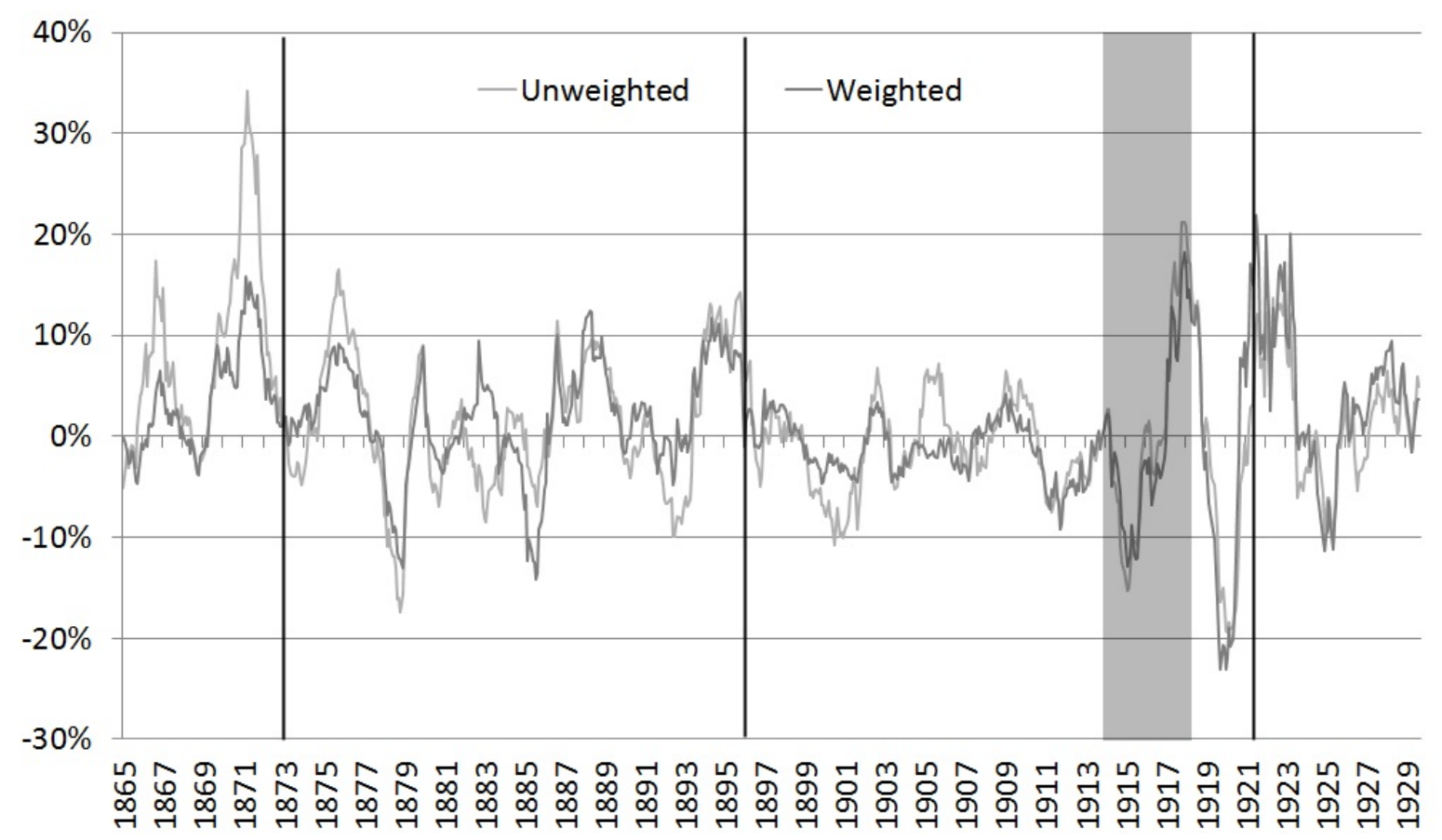

Figure 10. Year-on-year change in equity prices (weighted), by sector

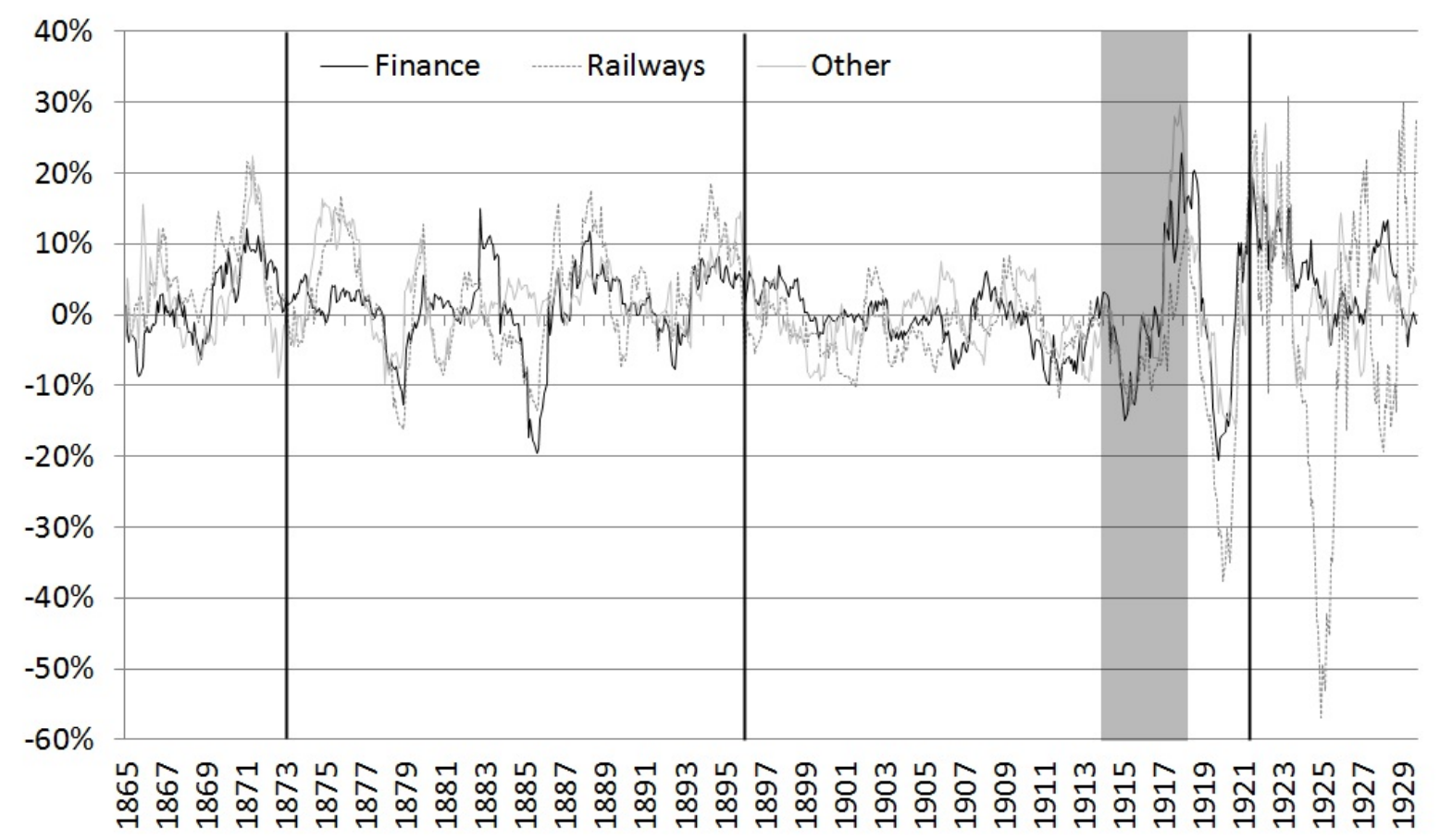

As suggested by the market capitalization figures, trends could vary significantly by sector. Figure 10 shows the year-on-year change in equity prices for the three broad sectors of Irish equity listings: railways, financials and other listings. What is immediately striking is the collapse in railway equity prices towards the end of the period, initially in 1920, as the War of Independence drew to a close and partition of the island became more likely, and then again in 1925, with the amalgamation of the 
remaining three listed railways in the Irish Free State and the subsequent collapse in the share price of the new monopoly, Great Southern (Ireland). A similar collapse in value happened for its Northern Irish counterpart, Great Northern of Ireland, whose price fell by more than a half in a single year. The effect of partition, and thus diminished economies of scale, on this non-traded industry would merit future research.

Table 4 provides a final look at overall trends in Irish equity prices by dividing our sample period into a series of sub-periods, each corresponding to a well-defined epoch in economic or political history. The first runs from the beginning of the sample in 1864 to the start of the so-called Long Depression of 1873-96. The second is the Long Depression itself, and the third is the period between 1896 and the outbreak of World War I. There follow: the war; the years between the end of the war and the signing of the Anglo-Irish Treaty, which saw the Irish War of Independence; and the period between the signing of the Treaty and the end of our sample. The table gives price indices for the start and end of each period, and average annual price changes for each period. It does so for the three (weighted) sectoral indices, as well as for the weighted and unweighted average Irish indices. Finally, it also includes comparable (end of year) data for the UK, using Grossman's (2002) annual index, thus providing a comparative perspective on the performance of Irish equity markets until 1913, when Grossman's index ends.

Table 4. Irish \& UK equity prices, levels and average annual changes, by period

\begin{tabular}{ccccccc}
\hline & Weighted & Finance & Railways & Other & Unweighted & $\begin{array}{c}\text { UK } \\
(\mathbf{1 8 7 0 - 1 9 1 3 )}\end{array}$ \\
\hline $\mathbf{1 8 6 4}$ & 100.0 & 100.0 & 100.0 & 100.0 & 100.0 & 100.0 \\
$\mathbf{1 8 7 3}$ & 134.8 & 122.6 & 157.5 & 118.6 & 184.3 & 126.4 \\
$\mathbf{1 8 9 6}$ & 195.3 & 151.8 & 235.8 & 228.9 & 237.6 & 242.7 \\
$\mathbf{1 9 1 4}$ & 155.7 & 130.2 & 161.6 & 186.0 & 190.7 & 373.9 \\
$\mathbf{1 9 1 8}$ & 161.3 & 141.9 & 146.8 & 209.9 & 205.0 & \\
$\mathbf{1 9 2 1}$ & 134.1 & 128.3 & 100.0 & 183.8 & 168.1 & \\
$\mathbf{1 9 3 0}$ & 182.7 & 202.6 & 58.6 & 269.0 & 198.2 & \\
\hline $\mathbf{1 8 6 4 - 7 3}$ & $3.4 \%$ & $2.3 \%$ & $5.2 \%$ & $1.9 \%$ & $7.0 \%$ & $8.1 \%$ \\
$\mathbf{1 8 7 3 - 9 6}$ & $1.6 \%$ & $0.9 \%$ & $1.8 \%$ & $2.9 \%$ & $1.1 \%$ & $2.9 \%$ \\
$\mathbf{1 8 9 6 - 1 9 1 4}$ & $-1.3 \%$ & $-0.9 \%$ & $-2.1 \%$ & $-1.1 \%$ & $-1.2 \%$ & $2.6 \%$ \\
$\mathbf{1 9 1 4 - 1 8}$ & $0.9 \%$ & $2.2 \%$ & $-2.4 \%$ & $3.1 \%$ & $1.8 \%$ & \\
$\mathbf{1 9 1 8 - 2 1}$ & $-6.0 \%$ & $-3.3 \%$ & $-12.0 \%$ & $-4.3 \%$ & $-6.4 \%$ & \\
$\mathbf{1 9 2 1 - 3 0}$ & $3.5 \%$ & $5.2 \%$ & $-5.8 \%$ & $4.3 \%$ & $1.8 \%$ & \\
\hline
\end{tabular}

Focusing on the lower half of the table, giving average annual price changes, it is clear that the Irish pre-war performance was relatively disappointing. While prices rose during the first two subperiods, they did so by substantially less than in the UK as a whole, while the Irish price declines of the 1896-1914 period contrast sharply with continued UK rises. Prices increases towards the end of World War I were sufficient to ensure that average prices were higher at the end of that conflict than at the beginning, despite major declines earlier on, although railway equity prices were an exception to the national trend. Prices fell sharply during the immediate postwar period and the War of Independence, but rose substantially after the Treaty, with railway equity prices again being an exception. 


\section{Stock market cycles, booms and busts}

If a boom is defined as a sustained period of annual growth in the price index of more than $10 \%$, then over the course of the six decades analysed there were five equity price booms, according to the market-cap weighted index. The first was early in the period, 1870-2, and was relatively evenly spread across all three sectors, although railway equities gained most. There were strong gains outside of financial equities in 1875-6 also, although the overall index never grew at a double-digit rate. The three-year boom in London equities 1879-81 does not appear to have affected Irish equities, although the second widespread Irish equity boom which took place in 1888-9 does coincide with strong gains in London (Grossman 2002). This boom was again more a feature of Irish railway equities (whose price index grew $16 \%$ in 1888 compared to $10 \%$ for financials and $7 \%$ elsewhere). The final railway-led boom occurred in 1894-6, when equity prices for the economy as a whole were growing at roughly $9 \%$ a year for 18 months.

There was no sustained increase in Irish equity prices - either across the board or within any of the three sectors - for the remainder of the pre-war period, with increases in end-of-year prices in just four of 14 years from 1900 to 1913 compared to ten years in London. The next Irish equities boom occurred as the war drew to a close, from late 1917 to early 1919. This boom was largely absent from the railway sector, where prices in mid-1919 were $1 \%$ down, year on year, compared to price growth of $19 \%$ for financial listings and $9 \%$ for other listings. The final boom occurred during 1922-4, just after Irish independence (for 26 of 32 counties; the remainder became Northern Ireland). It was prevalent across all three main sectors.

If an equity bust is defined as a sustained period of year-on-year contraction in equity prices of at least $5 \%$ (i.e. symmetric to booms around a base rate of return of $2.5 \%$ ), there were also five busts during the period. Two early international financial crises include Black Friday in May 1866, following the collapse of Overend, Gurney \& Company in London, and the Panic of 1873, following the collapse of Jay Cooke \& Company in the U.S. Neither appears to have long-lasting effects on Irish equity prices, although the 1866 crisis did see the financial index fall 7\% during the month of May 1866, after which the index of financials grew eight months in a row.

The first clear-cut equity bust in Ireland in the period analysed took place in 1878-9, following the collapse of the City of Glasgow Bank. Although initially a banking crisis, it affected railway equity prices more than other sectors (prices down $15 \%$ year-on-year in mid-1879, compared to $9 \%$ for financial and $7.5 \%$ for other listings).

The next Irish equity bust occurred in 1885-6 and appears to have been political in nature. In December 1885, the price of Irish financial equities fell 10.5\%, the same month that an election was held in the UK, with the result that the pro-devolution Irish Parliamentary Party held the balance of power with 86 of 670 seats. By mid-1886, the price of financial equities was down $20 \%$ year-on-year, compared to $14 \%$ for railway equities and no change for other equity listings.

Certain sectors experienced falling equity prices at different stages, for example railways in 1900-1 and financial equities in 1906-7, the latter coinciding with international uncertainty in banking, following the San Francisco earthquake and the rise in the Bank of England rate. The scale of equity price falls in Ireland following the financial crisis of 1907 was similar to that in England: end-of-year prices were $4.4 \%$ lower, compared to $4.3 \%$ lower in London (Grossman 2002). However, the next 
prolonged bust in Irish equity prices after 1886 did not occur until the 1910s. During this decade, there were three busts, the first occurring in 1911-3 and affecting financial listings disproportionately, which fell $13 \%$ during over this period, compared to falls of $9 \%$ for railway and other listings. This may relate to the Parliament Act of 1911, which effectively guaranteed that Irish devolution ("Home Rule") would occur within a matter of years (although that is not how things actually turned out).

The second equity bust of the 1910s occurred during the period 1915-7 but was concentrated in 1915. It affected all three sectors roughly equally, and may relate to a realization across Europe that the Great War would not be resolved quickly. ${ }^{15}$ The final bust of the decade started in 1919, immediately following the preceding boom, and lasted until 1921. Publication of monthly indices for other countries should allow us to assess the respective roles of national (War of Independence) and international factors in explaining this episode. This bust was particularly severe, with prices down $23 \%$ in a year by mid-1920, the only stock market crash, in Barro-Ursua (2008) terms, in the period analysed. The price of railway equities was most affected. This is curious, as during the subsequent Civil War (1922-3), where anti-Government forces systematically targeted road and rail infrastructure, railway equity prices were unaffected. The relative contributions of destruction of physical capital, increasing likelihood of partition and the war-related railway strike of 1920 (see Townshend 1979) in the decline of railway equities is a topic that merits further investigation. ${ }^{16}$

The final Irish equity bust of the period occurred in 1925-6 and was driven by the collapse in value of Irish railway listings. This was the middle of the final consolidation of Irish railways from five companies (1915-1924) to two (1925-present day), and in late 1925 the price of the surviving railway listings was down 50\% year-on-year. Financial and other equities were unaffected.

\section{Volatility}

A key contribution of a monthly equity price index over an annual index is what it reveals about the volatility of equity prices. Figure 11 graphs the ten-year coefficient of variation of equity price indices, by sector, from 1874 to 1930 . The dark black line, covering all equity listings, shows that the period started with high volatility in equity prices but that this eased considerably during the $1880 \mathrm{~s}$. The 1890s saw a return to more volatile prices, after which equity prices reached their least volatile level, just before the Great War.

The Great War saw increasing equity price volatility, which persisted until the end of the period. Within-sector volatility was noticeably greater, particularly for railways, which became very volatile in the 1920s, but also for financial listings, which exhibited a coefficient of variation of more than $15 \%$ during the 1920 s, compared to less than $5 \%$ in the early 1900 s.

\footnotetext{
${ }^{15}$ When more detailed data on the performance of British, French and Belgian equities, among others, become available to researchers, it will be possible to assess this assertion.

${ }^{16}$ The decline in railway equity prices predates the 'Munitions of War' strike (May-December 1920), which denied the British government use of Irish railways for moving armed forces and military supplies.
} 
Figure 11. Ten-year coefficient of variation in equity price indices, by sector

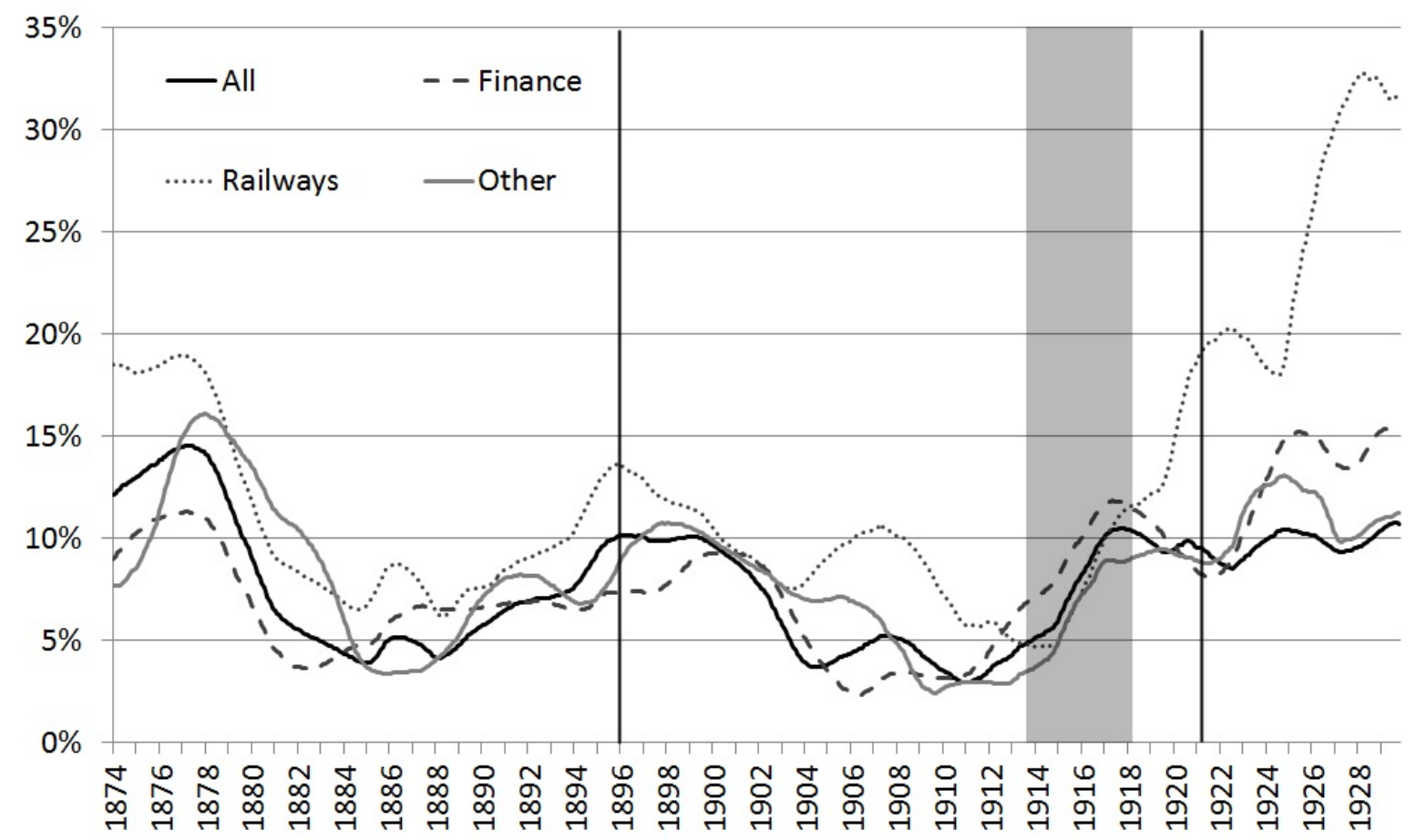

\section{Conclusions}

This paper has produced the first monthly index of Irish equity prices covering the period 1864-1930. It revises existing annual estimates of Irish equity prices for the period before the Great War and adds monthly data, giving insights into volatility as well as price returns. In addition to international financial crises, such as 1906-7, equity prices in Ireland appear to have been related to political events, with the 1885 election and resulting power of the Irish Parliamentary Party associated with a sharp fall in equity prices.

In contrast, the Irish Land Wars of the 1870 s and 1880 s do not appear to be reflected in equity price declines or volatility. Similarly, the 1916 Rising has almost no effect on equities. The only BarroUrsua crash of $20 \%$ or more in the sample coincides both with Ireland's War of Independence in 1919-21 and the crash in equity prices in the U.S. and UK (Chambers 2010, Jorion and Goetzmann 1999). Given the significant political events that took place in Ireland in the period covered, the relationship between the political and financial spheres is worthy of further study, as are sectorspecific developments.

What is noteworthy from a modern perspective is that boom-bust cycles in equity prices were largely absent in the pre-war period. For example, the strong equity price growth of 1871-2 was not undone in a bust that quickly followed, while the bust of 1878 followed a more moderate period of growth in equity prices. The bust of 1886 followed no boom at all. In contrast, from 1914 on, there was a rapid succession of booms and busts.

Taking the cut-offs used above ( $10 \%$ year-on-year growth as an equity price boom, $-5 \%$ as a bust), the pre-1914 Irish equity market was in a state of boom or bust just $12 \%$ of the time, compared to 
$40 \%$ of the time for the period 1914-1930. Put another way, the typical year pre-1914 saw 1.4 months of boom or bust in equity prices, compared to 4.8 months for the 1914-1930 period.

Figure 12. A monthly market-cap weighted equity price index for Ireland, 1825-1930 (Jan 1825=100)

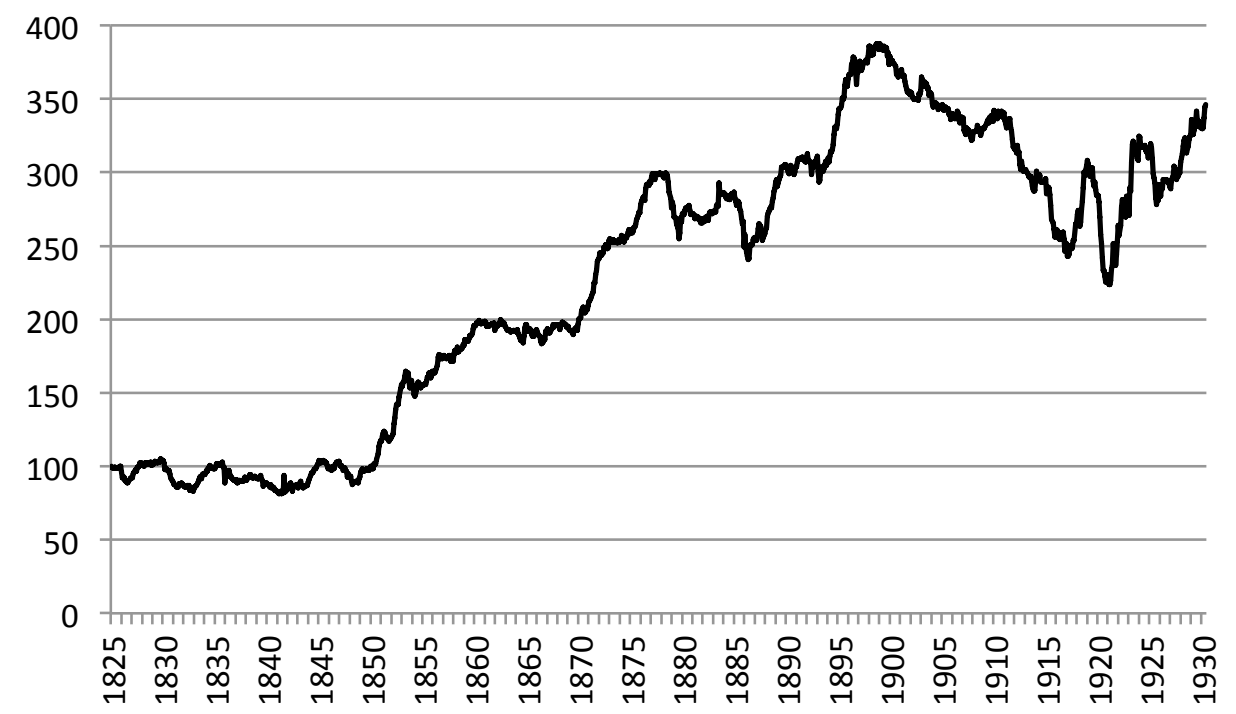

Finally, it is possible, by combining this work with Hickson \& Turner (2008), to construct a monthly equity price index for Ireland, weighted by market capitalization, for the period 1825-1930. This is shown in Figure 12, which combines the Hickson-Turner banking index 1825-1845 and overall index 1845-1864 with the information here, yielding more than a century of data on equity price returns and volatility. Future work will be required to merge these series with Ireland's official share price index, which begins in 1934. A related topic for future research is the relationship between capital gains and overall returns.

A priori, one might expect Irish equity prices to mirror those of Britain most closely, as both Ireland and Britain were part of the United Kingdom during most of this period. The annual index by Grossman (2002) suggests three booms in the pre-1913 period (1871, 1879-81 and 1888), the first and last of which are reflected in the Irish index presented here. The Grossman index finds, however, no equity price busts in the same period (as defined here, year-on-year falls of $5 \%$ or more), a stark contrast with Irish equities, where busts occurred in 1878, 1885-86 and again in 1911-13.

The results for Ireland are thus distinct enough to contribute to a wider literature on long-run equity returns. Comparing Ireland to other economies for which equity price indices exist, the lack of substantial price increases during much of the period analysed does not appear to be anomalous, but it is more pronounced in Ireland. Figure 13 shows the change in equity prices over the course of six decades, using data from published studies on the UK, U.S., France and Belgium. All these studies are market capitalization-weighted and thus comparable to the analysis here. 
Figure 13. Equity price changes, by decade and country, 1870-1930

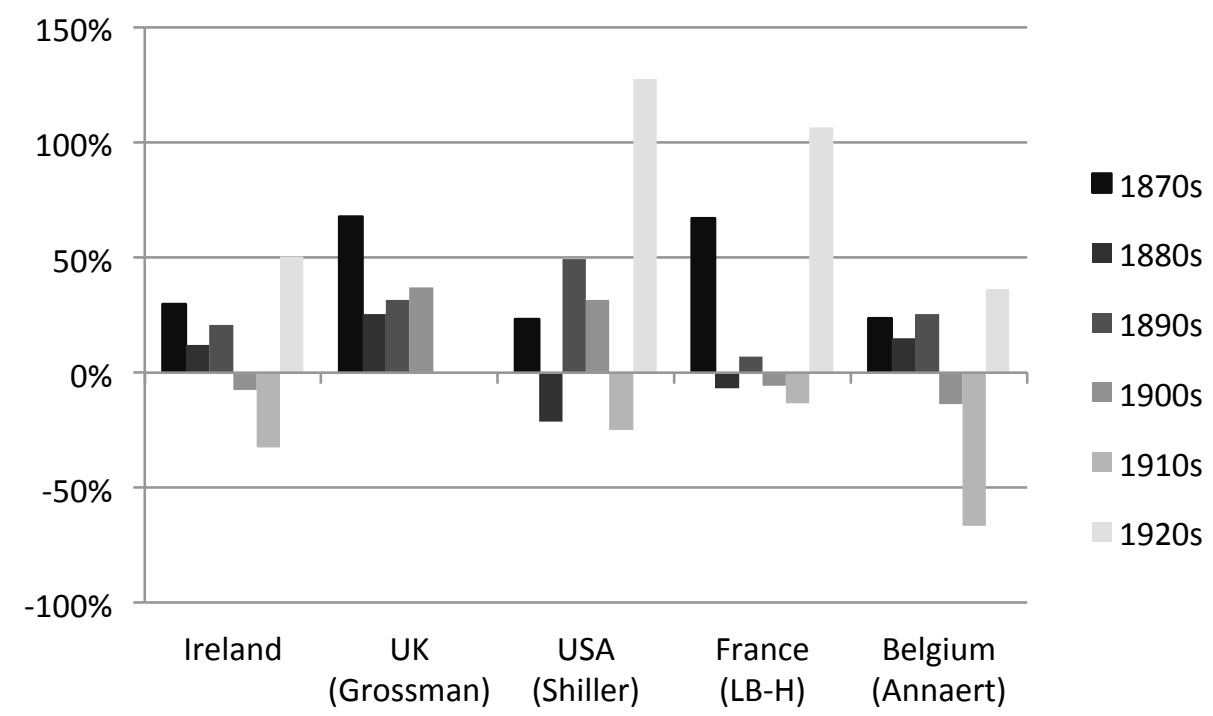

Notes: UK data stop in 1913; USA data refer to S\&P and start in 1871; Belgian data are inflation-

adjusted

The strong equity price appreciation seen in London equities is not reflected in pre-war US data or, generally speaking, in French or Belgian equities. Indeed, the pattern of changes in Irish equity prices mirrors those in Belgium more closely than those in the UK. International correlations in equity price trends, volatility and shocks during this period is likely to be an active topic of future research. For Ireland, the average long-run rate of change in equity prices over the period 1864-1930 was just $0.9 \%$. This adds to the evidence that any excess risk premium observed in the U.S. data may be exceptional, rather than widespread. 


\section{References}

Annaert, J., F. Buelens and M. Deloof (2012). "Long run stock returns: Evidence from Belgium 18382010." Available at SSRN: http://ssrn.com/abstract=2156803.

Arbulu, P. (1998). Le marché parisien des actions au XIXème siècle: performance et efficience d'un marché émergent. Unpublished PhD thesis, University of Orléans, 1998.

Barclays de Zoete Wedd Securities, Ltd (1995). The BZW Equity-Gilt Study: Investment in the London Stock Market Since 1918. London: Barclays de Zoete Wedd Securities, Ltd.

Barro R.J. and J. F. Ursua (2008). "Macroeconomic crises since 1870." Brookings Papers on Economic Activity 39(1): 255-350.

Bowley, A.L., G.L. Schwartz and K.C. Smith (1931). A New Index of Prices of Securities. London: Royal Economic Society and London and Cambridge Economic Service.

Chambers, D. (2010). “Going public in interwar Britain." Financial History Review 17: 51-71.

Cowles, A. (1939). Common Stock Indices. Bloomington: Principia Press.

Goetzmann, W. N., R.G. Ibbotson and L. Peng (2001). "A new historical database for the NYSE 1815 to 1925: performance and predictability." Journal of Financial Markets 4: 1-32.

Goetzmann, W. N. and P. Jorion (1999). "Re-emerging markets." The Journal of Financial and Quantitative Analysis 34: 1-32.

Grossman, R. S. (2002). "New indices of British equity prices, 1870-1913." Journal of Economic History 62: 121-146.

Grossman, R. S. and M. Imai (2013). "Contingent capital and bank risk-taking among British banks before World War I." Economic History Review 66: 132-155.

Hickson, C. R. and J.D. Turner (2005). "The rise and decline of the Irish stock market, 1865-1913." European Review of Economic History 9: 3-33.

Hickson, C. R. and J.D. Turner (2008). "Pre-and post-famine indices of Irish equity prices." European Review of Economic History 12: 3-38.

Hope, E. and B. M. Lucey (2007). "Daily seasonality in 19th century stocks--some evidence from the Dublin stock exchange." Applied Economics Letters 14: 277-282.

Jorion, P. and W.N. Goetzman (1999). "Global stock markets in the twentieth century." Journal of Finance 54: 953-980.

Le Bris, D. and P.-C. Hautcœur (2010). "A challenge to triumphant optimists? A blue chips index for the Paris stock exchange, 1854-2007." Financial History Review 17: 141-183.

Lucey, B. M. and S. Whelan (2004). "Monthly and semi-annual seasonality in the Irish equity market 1934-2000." Applied Financial Economics 14: 203-208. 
Lynch, P. and J. Vaizey (1960). Guinness's Brewery in the Irish Economy, 1759-1876. Cambridge: Cambridge University Press.

Neal, L. (1985). "Integration of international capital markets: quantitative evidence from the eighteenth to twentieth centuries." Journal of Economic History 45: 219-226.

Ó Gráda, C. (1994). Ireland: A New Economic History 1780-1939. Oxford: Oxford University Press.

Ó Gráda, C. (2003). “Moral hazard and quasi-central banking: should the Munster Bank have been allowed to fail?" In D. Dickson and C. Ó Gráda (eds.), Refiguring Ireland: Essays in Honour of L.M. Cullen. Dublin: Lilliput.

O'Rourke, K. (1994). "The economic impact of the famine in the short and long run." American Economic Review 84: 309-313.

Shiller, R. (2013). Long term stock, bond, interest rate and consumption data. Available online at: http://www.econ.yale.edu/ shiller/data.htm

Smith, K.C. and G.F. Horne (1934). An Index Number of Securities, 1867-1914. London: Royal Economic Society and London and Cambridge Economic Service.

Thomas, W.A. (1986). The Stock Exchanges of Ireland. Liverpool: Francis Cairns.

Townshend C. (1979). "The Irish railway strike of 1920: industrial action and civil resistance in the struggle for independence." Irish Historical Studies 21: 265-282.

Whelan, S. (1999). From Canals to Computers, The Friends First Guide to Long-Term Investment in Ireland. Dublin: Friends First.

Zussman, A., N. Zussman and M.Ø. Nielsen (2008). "Asset market perspectives on the IsraeliPalestinian conflict." Economica 75: 84-115. 


\section{Appendix 1: Guinness \& preference listings}

\section{An index including Guinness}

As described in the main text, Guinness's brewery was not listed on the Dublin stock exchange after it became a publicly listed company in 1887. It was an increasingly internationally focused company; nonetheless, its headquarters remained in Dublin during this period and thus a comparison of equity price indices with and without Guinness is worthwhile. Figure A1 thus gives monthly prices indices for Irish equities both without (as in the text) and with Guinness included. The right-hand scale shows the percentage weight of Guinness in the index if included. This reached almost $75 \%$ during the mid-1920s, meaning in practice that at that stage the Irish equity price index including Guinness mirrors trends in the market capitalization of Guinness. As can be seen, Guinness out-performed other Irish stock prices from World War I onwards.

Figure A1. Equity price indices excluding and including Guinness (and \% of Guinness in total market capitalization, if included), 1864-1930

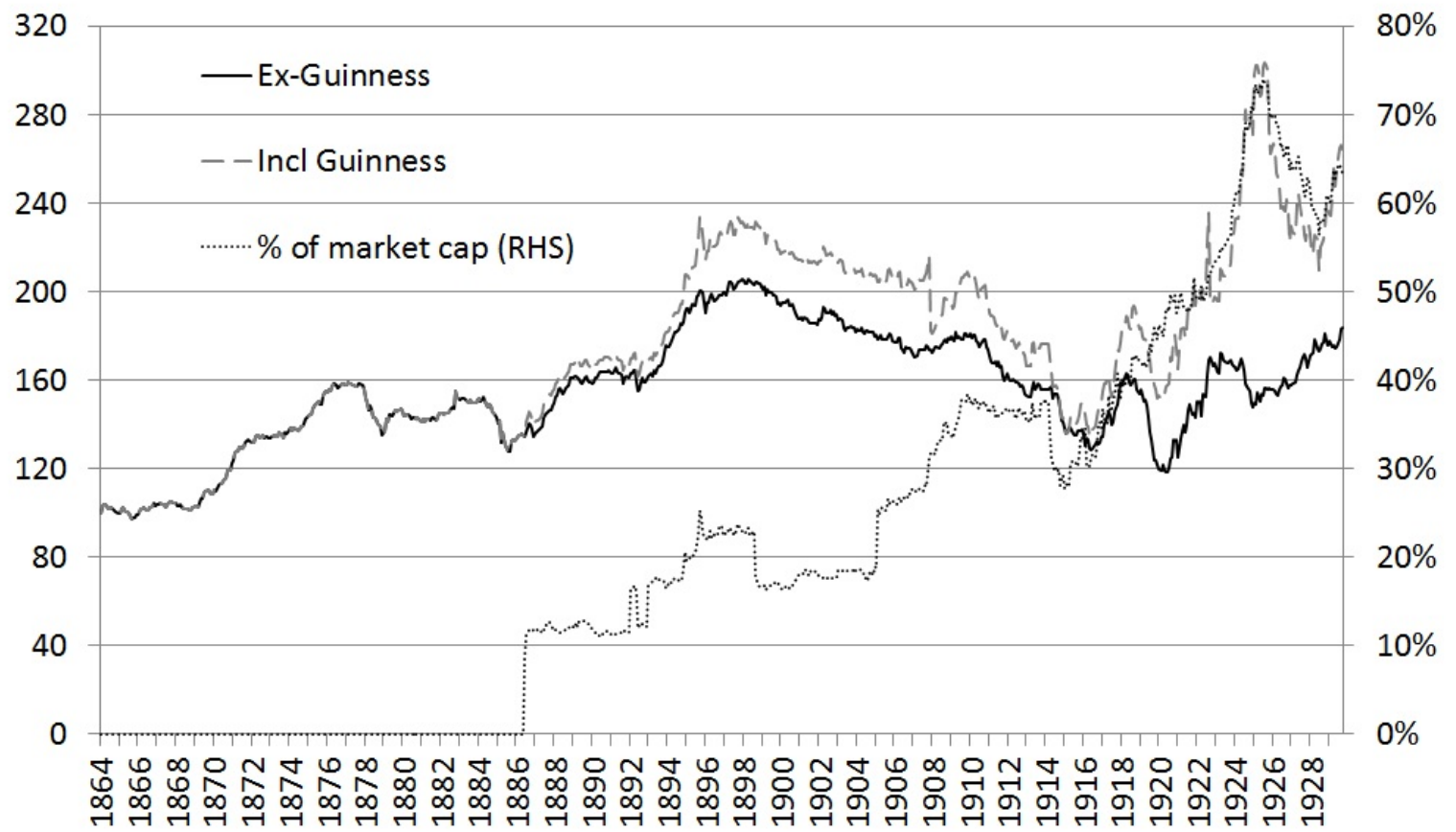

\section{An index including preference shares}

Excluded from the core indices presented are preference shares, i.e. those with a stated rate of return of some sort. As in Hickson \& Turner (2008) (but unlike in Hickson and Turner 2005), these are treated here as between pure equity and pure debt, and therefore are not included. Figure A2 presents price indices for all sectors, and also for railways, which comprise the majority of preference listings, for all listings excluding and including preference share listings. For the overall index, there are only small differences, with the index including preference listings performing slightly better in the first half of the sample, and slightly worse thereafter. For the rail sector, there is a more pronounced difference, but only towards the end of the sample, at which stage there are a limited number of listings of any description. 
Figure A2. Equity price indices excluding and including preference listings, 1864-1930

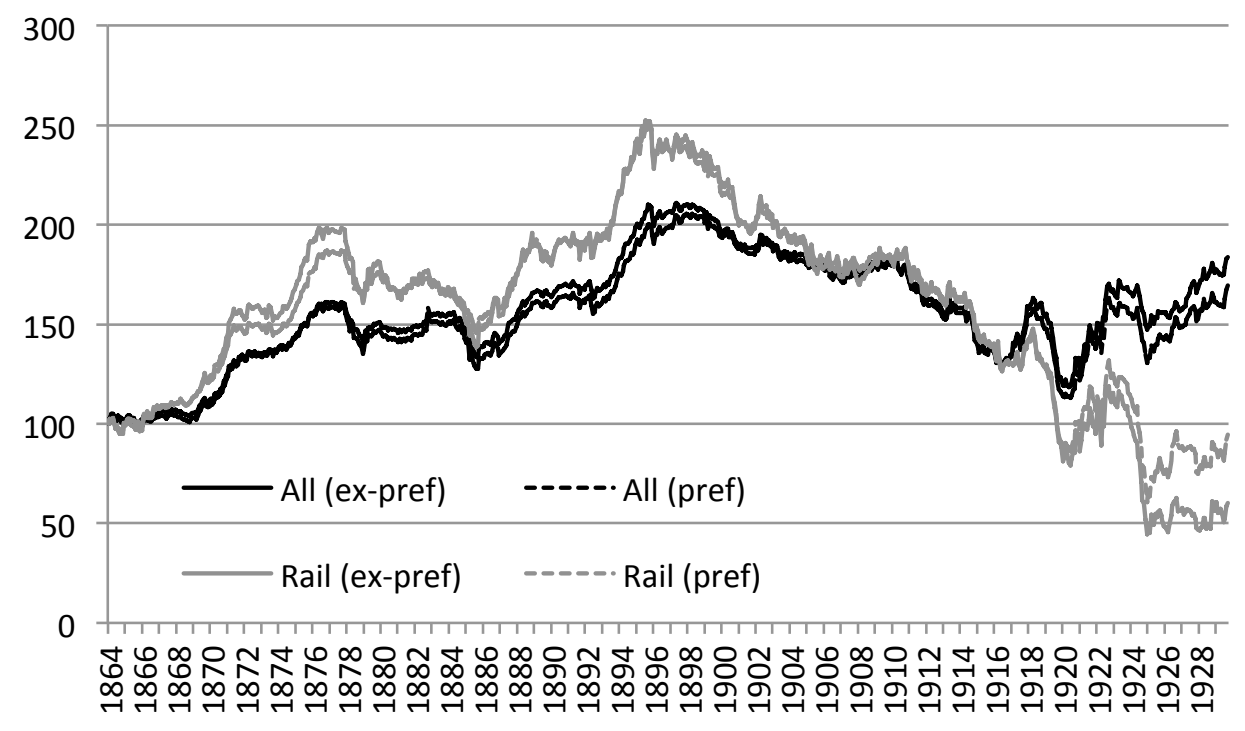

\section{An index excluding months with no transactions}

Currently, the index is constructed so that months where no transactions occur (indicated "..." in the Investor's Monthly Manual) are treated as having the same price as the previous month; i.e., in the absence of any other signals, the previously existing price is assumed to have applied. This is to maximise the information included in the construction of the equity price indices. For example, consider a listing with the following price information for January-April: 101, 103, .., 102. The indices presented in the main text assume that in the absence of any market transactions, the best estimate of the value of the listing in March is the same as in February (i.e. a price of 103 is assumed for March), thus capturing the fall in value between February and April as a change in April. If instead we treated March as a missing month, there would be no monthly price change information available for March (relative to February) or April (relative to March), and thus the fall in value of the listing would be omitted. However, for other listings, continued missing price information may indicate a lack of liquidity and thus the most recent price information may be out-of-date.

The impact of the method used, compared to the alternative, is presented in Figures A3-A6. Figure A3 shows equity price indices, both weighted (black lines) and unweighted (grey), for series including ("Incl", as per the main text, solid lines) and excluding ("Excl", dashed lines) months with missing price information. The weighted equity price index is almost identical across both methods, suggesting that our findings are robust to how we treat missing/illiquid equities. For the unweighted indices, a difference between the two series emerges in the late 1890s, although the overall trends are still the same.

Figures A4-A6 examine the three broad sectors: Railways, Financial, and Other. The most pronounced differences are in the unweighted series, in particular for railway listings, suggesting that issues of liquidity and missing price information are most severe there. Nonetheless, particularly for the weighted indices, the overall trends are very highly correlated across both methods. 
Figure A3. Overall equity price indices excluding and including missing months, 1864-1930

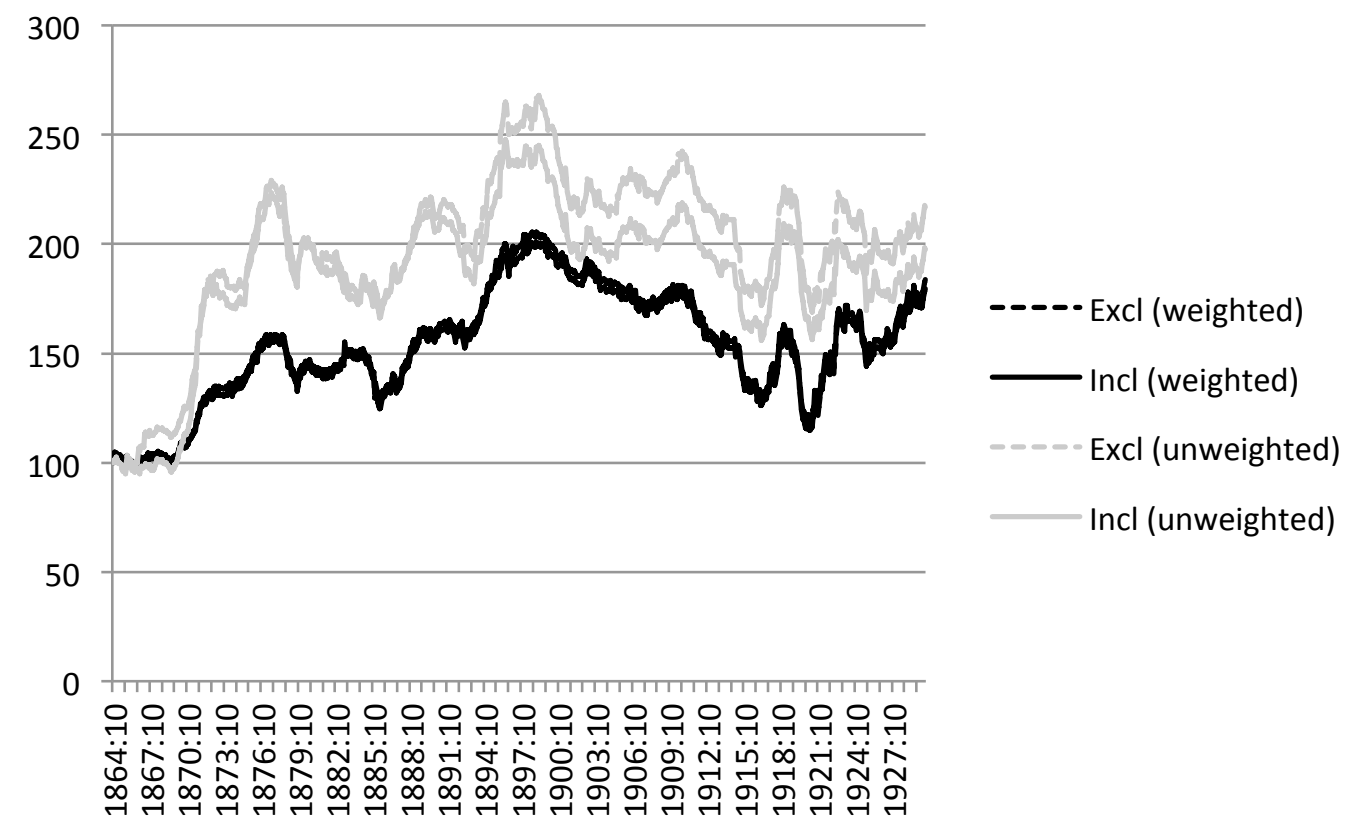

Figure A4. Railway equity price indices excluding and including missing months, 1864-1930

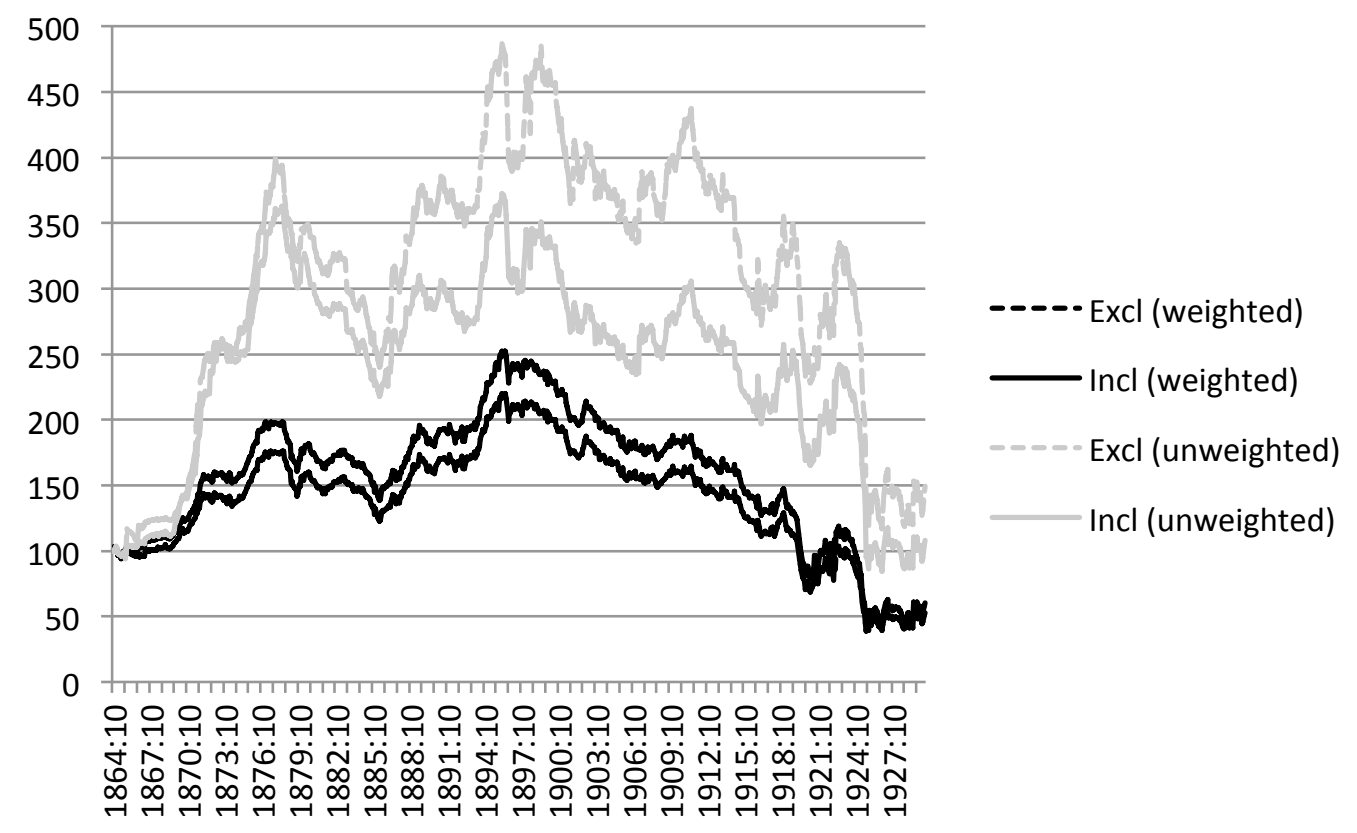


Figure A5. Financial equity price indices excluding and including missing months, 1864-1930

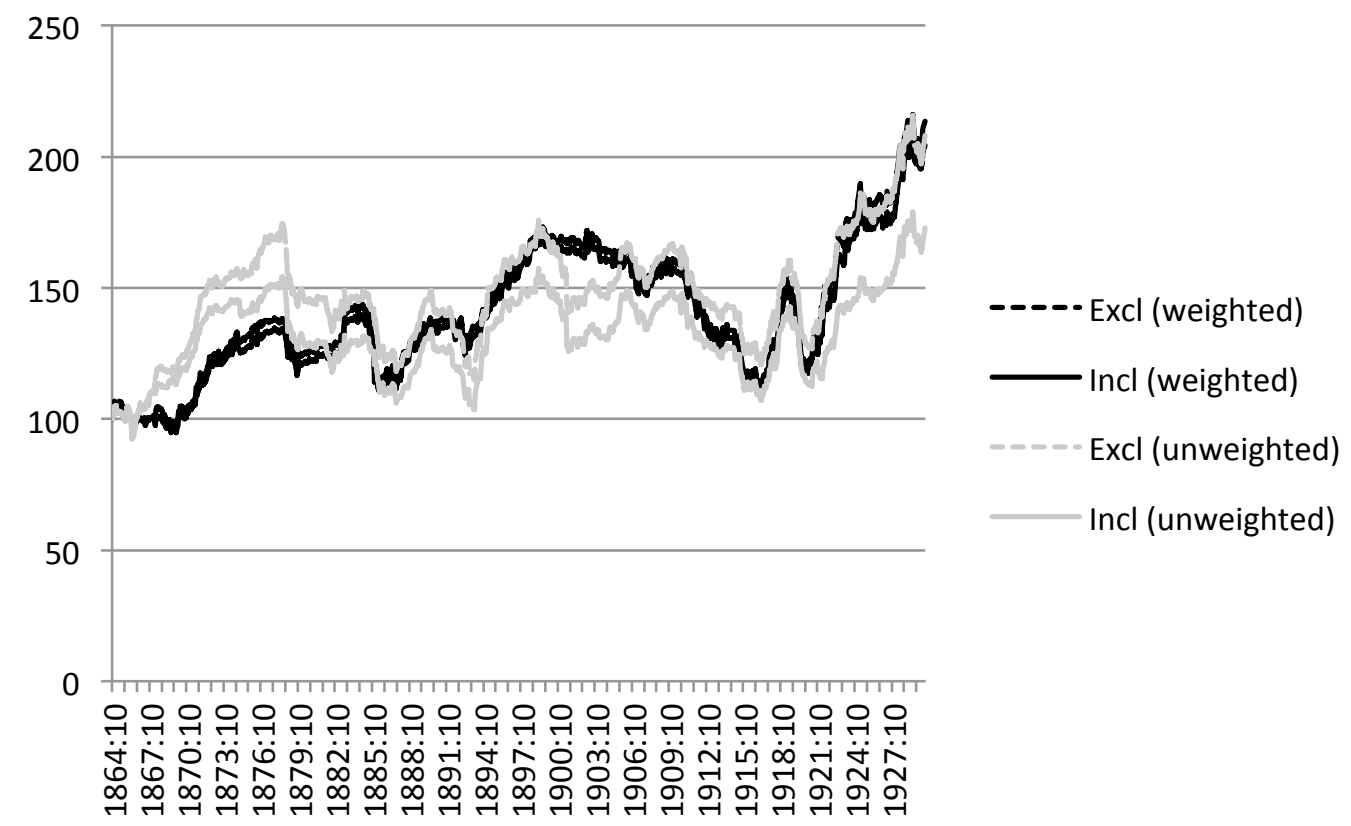

Figure A6. Other equity price indices excluding and including missing months, 1864-1930

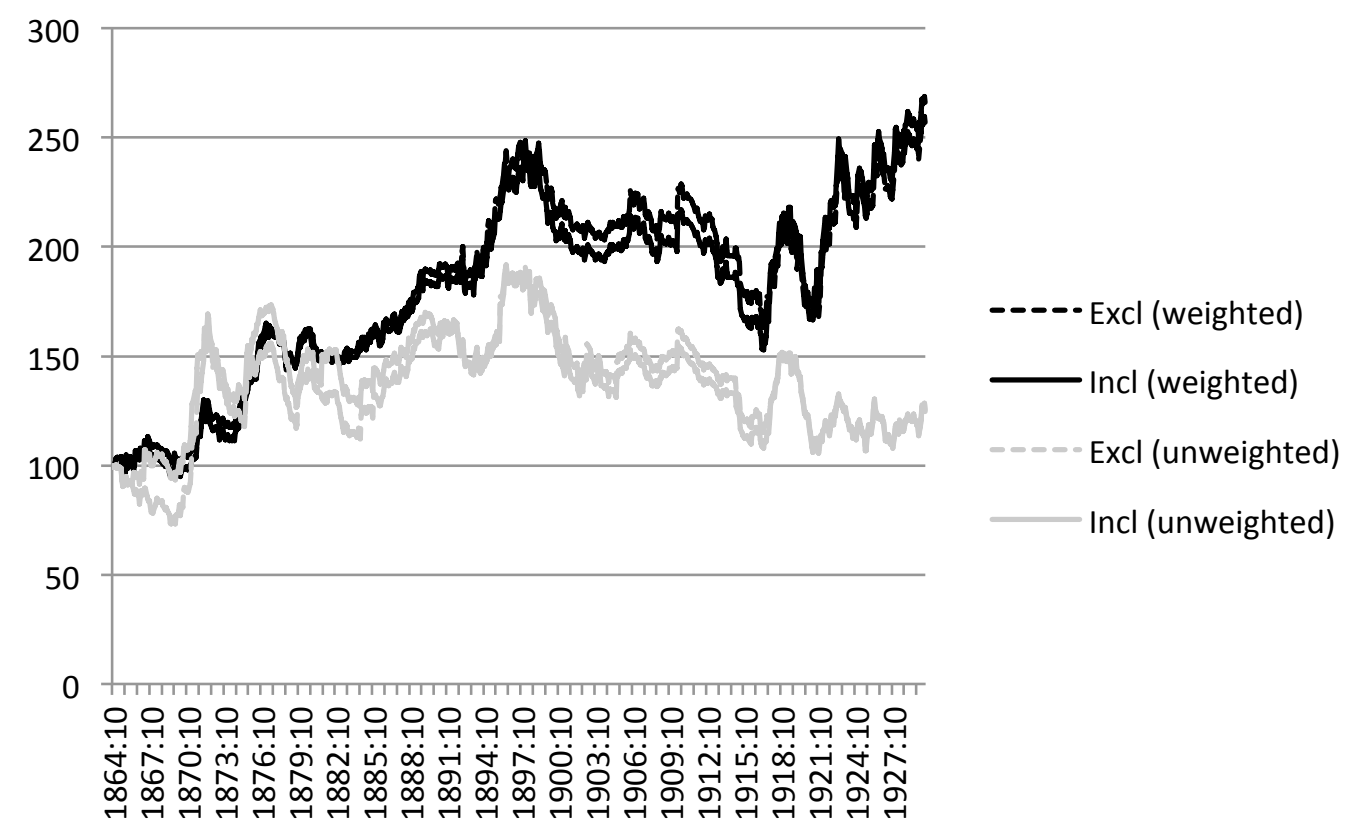


Appendix 2: List of companies analysed

\begin{tabular}{|c|c|c|c|c|c|}
\hline Company & Additional listings & Sector & Exchanges & Start & End \\
\hline Bank of Ireland & & Finance & $\mathrm{D}$ & $1864: 10$ & $1930: 6$ \\
\hline Belfast Banking Company & "1883 New"; "New" & Finance & $B, D$ & $1864: 10$ & 1918:1 \\
\hline Belfast Discount, Ltd. & & Finance & B & $1882: 9$ & 1901:1 \\
\hline $\begin{array}{l}\text { Discount Corporation of } \\
\text { Ireland }\end{array}$ & & Finance & B & $1886: 1$ & $1894: 5$ \\
\hline English \& Irish Bank, Ltd & & Finance & $\mathrm{D}$ & $1864: 10$ & $1864: 10$ \\
\hline European Bank, Ltd & & Finance & $\mathrm{D}$ & $1864: 10$ & $1866: 9$ \\
\hline Hibernian, Limited & "New" & Finance & D & $1868: 3$ & 1873:5 \\
\hline Munster \& Leinster Bank Ltd. & & Finance & $\mathrm{D}$ & $1886: 3$ & 1930:6 \\
\hline Munster Bank Ltd. & "New" & Finance & $\mathrm{D}$ & $1865: 9$ & $1886: 12$ \\
\hline National Bank & & Finance & $D, L$ & 1864:10 & 1930:6 \\
\hline $\begin{array}{l}\text { National Discount of Ireland, } \\
\text { Limited }\end{array}$ & & Finance & $\mathrm{D}$ & $1876: 3$ & $1883: 9$ \\
\hline $\begin{array}{l}\text { National, Fire, Life \& Marine } \\
\text { (Ireland) }\end{array}$ & & Finance & $\mathrm{D}$ & 1864:10 & 1903:9 \\
\hline Northern Banking Company & $\begin{array}{l}\text { "1883 Issue"; "New } \\
\text { B" }\end{array}$ & Finance & B & $1864: 10$ & 1926:1 \\
\hline $\begin{array}{l}\text { Patriotic Insurance (Ireland) } \\
\text { Fire \& Life }\end{array}$ & & Finance & $\mathrm{D}$ & 1864:10 & 1906:4 \\
\hline Provincial Bank of Ireland & "New" & Finance & $D, L$ & 1864:10 & 1930:6 \\
\hline Royal Bank (Ireland) & & Finance & $\mathrm{D}$ & $1864: 10$ & 1930:6 \\
\hline Ulster Banking Company & "New (1883)" & Finance & $B, D$ & $1864: 10$ & 1918:1 \\
\hline Union Bank of Ireland & & Finance & $\mathrm{D}$ & $1864: 10$ & 1868:1 \\
\hline Athenry \& Tuam (W\&L) & & Railways & $\mathrm{D}$ & $1864: 10$ & $1888: 9$ \\
\hline Belfast \& County Down & & Railways & $B, D$ & 1864:10 & $1925: 10$ \\
\hline Belfast \& Northern Counties & & Railways & $B, D$ & 1864:10 & 1903:9 \\
\hline $\begin{array}{l}\text { Cork \& Bandon / C.B.\& South } \\
\text { Co.s }\end{array}$ & & Railways & $\mathrm{D}$ & 1864:10 & 1915:8 \\
\hline $\begin{array}{l}\text { Cork \& Macroom / C. \& } \\
\text { Limerick Direct }\end{array}$ & & Railways & $\mathrm{D}$ & $1876: 9$ & $1890: 12$ \\
\hline Cork, Blackrock \& Passage & & Railways & $\mathrm{D}$ & $1864: 10$ & $1897: 10$ \\
\hline Dublin \& Belfast Junction & & Railways & $B, D$ & $1864: 10$ & $1875: 2$ \\
\hline Dublin \& Drogheda & & Railways & $\mathrm{D}$ & 1864:10 & $1875: 2$ \\
\hline Dublin \& Kingstown (DWW) & & Railways & $\mathrm{D}$ & $1864: 10$ & $1889: 4$ \\
\hline Dublin \& Meath & & Railways & $\mathrm{D}$ & 1864:10 & 1889:4 \\
\hline $\begin{array}{l}\text { Dublin \& South-East / D., } \\
\text { Wicklow \& Wexford }\end{array}$ & "1864"; "1865" & Railways & $\mathrm{D}$ & 1864:10 & $1924: 12$ \\
\hline Finn Valley & & Railways & $\mathrm{D}$ & 1865:5 & 1888:9 \\
\hline (Great) Northern of Ireland & & Railways & $B, D$ & $1875: 3$ & 1930:6 \\
\hline $\begin{array}{l}\text { Great Northern \& Western } \\
\text { (MGW) }\end{array}$ & & Railways & $\mathrm{D}$ & $1865: 12$ & 1889:4 \\
\hline Great Southern \& Western & & Railways & $\mathrm{D}$ & 1864:10 & 1930:6 \\
\hline Irish Northwestern & "B" & Railways & $\mathrm{D}$ & $1864: 10$ & $1875: 12$ \\
\hline Irish South-Eastern & & Railways & $\mathrm{D}$ & $1864: 10$ & $1867: 5$ \\
\hline Limerick \& Ennis & & Railways & $\mathrm{D}$ & $1865: 1$ & $1874: 2$ \\
\hline Limerick \& Foynes & & Railways & $\mathrm{D}$ & $1864: 10$ & $1874: 11$ \\
\hline Londonderry \& Enniskillen & & Railways & $\mathrm{D}$ & $1864: 10$ & 1883:12 \\
\hline
\end{tabular}




\begin{tabular}{|c|c|c|c|c|c|}
\hline (GNI) & & & & & \\
\hline Midland Great Western & & Railways & $\mathrm{D}$ & $1864: 10$ & $1924: 10$ \\
\hline $\begin{array}{l}\text { Newry, Warrenpoint \& } \\
\text { Rostrevor }\end{array}$ & & Railways & $B, D$ & 1864:10 & $1867: 12$ \\
\hline $\begin{array}{l}\text { Portadown, Dungannon \& } \\
\text { Omagh Junction }\end{array}$ & & Railways & $B, D$ & $1865: 4$ & $1876: 4$ \\
\hline Ulster & $\begin{array}{l}\text { "Clones Extension"; } \\
\text { "Monaghan" }\end{array}$ & Railways & $B, D$ & 1864:10 & $1876: 4$ \\
\hline Waterford \& Central & & Railways & $D, L$ & $1864: 10$ & 1891:3 \\
\hline $\begin{array}{l}\text { Waterford \& Limerick / W. L. } \\
\text { \& Western }\end{array}$ & & Railways & $\mathrm{D}$ & $1864: 10$ & 1900:12 \\
\hline Waterford \& Tramore & & Railways & $\mathrm{D}$ & $1865: 1$ & 1891:3 \\
\hline City of Dublin Brewery Ltd. & & $\begin{array}{l}\text { Other: Brewing \& } \\
\text { Distilling }\end{array}$ & $\mathrm{D}$ & $1866: 2$ & $1885: 2$ \\
\hline Dublin Distillers, Ltd & & $\begin{array}{l}\text { Other: Brewing \& } \\
\text { Distilling }\end{array}$ & $D, L$ & 1890:2 & $1905: 10$ \\
\hline Dunville \& Co., Ltd & & $\begin{array}{l}\text { Other: Brewing \& } \\
\text { Distilling }\end{array}$ & $B, D$ & 1882:5 & 1930:6 \\
\hline Kinahan \& Co. & & $\begin{array}{l}\text { Other: Brewing \& } \\
\text { Distilling }\end{array}$ & $\mathrm{D}$ & 1895:1 & 1908:4 \\
\hline $\begin{array}{l}\text { Arnott \& Co. (Dublin), } \\
\text { Limited }\end{array}$ & & $\begin{array}{l}\text { Other: Clothing \& } \\
\text { Drapers }\end{array}$ & $\mathrm{D}$ & $1877: 5$ & 1899:4 \\
\hline $\begin{array}{l}\text { Arnott (John) \& Co. of } \\
\text { Belfast, Limited }\end{array}$ & & $\begin{array}{l}\text { Other: Clothing \& } \\
\text { Drapers }\end{array}$ & $B, D$ & $1877: 2$ & $1895: 4$ \\
\hline Brookfield Linen Limited & & $\begin{array}{l}\text { Other: Clothing \& } \\
\text { Drapers }\end{array}$ & B & 1895:1 & 1915:2 \\
\hline Burke (Ed. \& John) & & $\begin{array}{l}\text { Other: Clothing \& } \\
\text { Drapers }\end{array}$ & $\mathrm{D}$ & 1891:1 & 1930:6 \\
\hline Cannock \& Co., Limited & & $\begin{array}{l}\text { Other: Clothing \& } \\
\text { Drapers }\end{array}$ & $\mathrm{D}$ & $1878: 9$ & 1911:12 \\
\hline $\begin{array}{l}\text { Dublin Drapery Warehouse, } \\
\text { Ltd. }\end{array}$ & & $\begin{array}{l}\text { Other: Clothing \& } \\
\text { Drapers }\end{array}$ & D & $1882: 7$ & $1883: 10$ \\
\hline Falls Flax Spinning Limited & & $\begin{array}{l}\text { Other: Clothing \& } \\
\text { Drapers }\end{array}$ & $B, D$ & $1866: 4$ & 1869:12 \\
\hline Lyons, T. \& Co., Ltd. & "Ditto" & $\begin{array}{l}\text { Other: Clothing \& } \\
\text { Drapers }\end{array}$ & C & 1880:3 & 1889:2 \\
\hline McBirney \& Co., Limited & & $\begin{array}{l}\text { Other: Clothing \& } \\
\text { Drapers }\end{array}$ & $\mathrm{D}$ & $1876: 12$ & 1890:11 \\
\hline Pim Brothers, Ltd. & & $\begin{array}{l}\text { Other: Clothing \& } \\
\text { Drapers }\end{array}$ & $\mathrm{D}$ & 1890:2 & $1924: 7$ \\
\hline Webb (J.H.) \& Co., Limited & & $\begin{array}{l}\text { Other: Clothing \& } \\
\text { Drapers }\end{array}$ & $\mathrm{D}$ & 1877:1 & 1922:3 \\
\hline $\begin{array}{l}\text { York Street Flax Spinning } \\
\text { Limited }\end{array}$ & & $\begin{array}{l}\text { Other: Clothing \& } \\
\text { Drapers }\end{array}$ & B & $1865: 2$ & 1919:8 \\
\hline $\begin{array}{l}\text { Alliance Dublin Consumers } \\
\text { Gas }\end{array}$ & $\begin{array}{l}\text { "B"; "C1"; "C2"; "7\% } \\
\text { max" }\end{array}$ & Other: Gas & $\mathrm{D}$ & 1910:1 & 1930:6 \\
\hline $\begin{array}{l}\text { Commercial Gas Co. of } \\
\text { Ireland }\end{array}$ & & Other: Gas & $\mathrm{D}$ & $1865: 1$ & 1868:6 \\
\hline Cork Gas & "New shares" & Other: Gas & C & $1865: 8$ & $1884: 12$ \\
\hline Carysfort (Ireland), Limited & & Other: Mining & $\mathrm{D}$ & 1864:10 & 1868:2 \\
\hline Connorree (Limited) & & Other: Mining & $\mathrm{D}$ & 1864:10 & $1873: 12$ \\
\hline General Mining Co. (Ireland) & & Other: Mining & $D$ & $1864: 10$ & 1872:12 \\
\hline $\begin{array}{l}\text { Great Northern of Ireland } \\
\text { [mines] }\end{array}$ & & Other: Mining & $\mathrm{D}$ & $1866: 12$ & 1869:6 \\
\hline
\end{tabular}




\begin{tabular}{|c|c|c|c|c|}
\hline Killaloe Slate Co. (Ltd.) & Other: Mining & $\mathrm{D}$ & $1864: 10$ & $1901: 5$ \\
\hline Mining Co. of Ireland & Other: Mining & $\mathrm{D}$ & $1864: 10$ & 1891:5 \\
\hline Wicklow Copper & Other: Mining & $\mathrm{D}$ & $1864: 10$ & $1886: 12$ \\
\hline Dublin South City Market & $\begin{array}{l}\text { Other: } \\
\text { Miscellaneous }\end{array}$ & $\mathrm{D}$ & $1882: 7$ & 1930:6 \\
\hline Dublin, Exhibition Limited & $\begin{array}{l}\text { Other: } \\
\text { Miscellaneous }\end{array}$ & $\mathrm{D}$ & $1865: 1$ & 1868:5 \\
\hline Goulding (W.H. \& M.) Limited & $\begin{array}{l}\text { Other: } \\
\text { Miscellaneous }\end{array}$ & C, D & 1878:2 & 1926:1 \\
\hline Gresham Hotel Company, Ltd & $\begin{array}{l}\text { Other: } \\
\text { Miscellaneous }\end{array}$ & $\mathrm{D}$ & $1866: 3$ & 1868:6 \\
\hline Henry Street Warehouse, Ltd. & $\begin{array}{l}\text { Other: } \\
\text { Miscellaneous }\end{array}$ & $\mathrm{D}$ & $1882: 7$ & $1890: 12$ \\
\hline $\begin{array}{l}\text { McKenzie (Thos.) \& Sons, } \\
\text { Limited }\end{array}$ & $\begin{array}{l}\text { Other: } \\
\text { Miscellaneous }\end{array}$ & $\mathrm{D}$ & $1877: 2$ & 1889:2 \\
\hline McSwiney \& Co., Limited & $\begin{array}{l}\text { Other: } \\
\text { Miscellaneous }\end{array}$ & $\mathrm{D}$ & $1876: 9$ & 1882:6 \\
\hline Seddon's Pneumatic Tyres & $\begin{array}{l}\text { Other: } \\
\text { Miscellaneous }\end{array}$ & $D, L$ & 1893:7 & $1894: 10$ \\
\hline Thom (Alex.) \& Co. Ltd. & $\begin{array}{l}\text { Other: } \\
\text { Miscellaneous }\end{array}$ & $\mathrm{D}$ & 1895:1 & 1905:4 \\
\hline Dublin Artisans Dwellings & Other: Real Estate & $\mathrm{D}$ & $1904: 4$ & 1930:6 \\
\hline $\begin{array}{l}\text { Irish Civil Service Permanent } \\
\text { Building }\end{array}$ & Other: Real Estate & $\mathrm{D}$ & $1876: 12$ & 1912:1 \\
\hline Irish Land Co. & Other: Real Estate & D & $1864: 10$ & $1872: 3$ \\
\hline Belfast Steam Ship & $\begin{array}{l}\text { Other: Shipping, } \\
\text { Canals \& Docks }\end{array}$ & $B, D$ & $1873: 4$ & 1910:9 \\
\hline British and Irish Steam & $\begin{array}{l}\text { Other: Shipping, } \\
\text { Canals \& Docks }\end{array}$ & $\mathrm{D}$ & $1864: 10$ & 1897:10 \\
\hline City of Dublin Steam & $\begin{array}{l}\text { Other: Shipping, } \\
\text { Canals \& Docks }\end{array}$ & $\mathrm{D}$ & 1864:10 & 1910:10 \\
\hline Cork Steam Packet & $\begin{array}{l}\text { Other: Shipping, } \\
\text { Canals \& Docks }\end{array}$ & C & 1880:10 & $1887: 2$ \\
\hline Dublin \& Glasgow Steam & $\begin{array}{l}\text { Other: Shipping, } \\
\text { Canals \& Docks }\end{array}$ & $\mathrm{D}$ & $1865: 1$ & $1896: 10$ \\
\hline $\begin{array}{l}\text { Dublin \& L'pool Steam } \\
\text { Shipbuilding }\end{array}$ & $\begin{array}{l}\text { Other: Shipping, } \\
\text { Canals \& Docks }\end{array}$ & D & $1864: 10$ & 1910:7 \\
\hline $\begin{array}{l}\text { Dundalk \& Newry Steam } \\
\text { Packet }\end{array}$ & $\begin{array}{l}\text { Other: Shipping, } \\
\text { Canals \& Docks }\end{array}$ & $\mathrm{D}$ & 1864:10 & $1896: 9$ \\
\hline Grand Canal & $\begin{array}{l}\text { Other: Shipping, } \\
\text { Canals \& Docks }\end{array}$ & $\mathrm{D}$ & $1864: 10$ & 1895:1 \\
\hline Belfast Street Tramways & Other: Tramways & $B, L$ & $1877: 9$ & 1905:9 \\
\hline $\begin{array}{l}\text { Dublin United Tramways, } \\
\text { Limited }\end{array}$ & Other: Tramways & $D, L$ & 1871:7 & 1930:6 \\
\hline $\begin{array}{l}\text { North Dublin Street } \\
\text { Tramways }\end{array}$ & Other: Tramways & $\mathrm{D}$ & 1878:2 & $1880: 10$ \\
\hline
\end{tabular}

Legend: $\mathrm{D}=$ Dublin, $\mathrm{B}=$ Belfast, $\mathrm{C}=$ Cork, $\mathrm{L}=$ London 
Appendix 3: Monthly indices for Irish equity listings, 1864-1930

\begin{tabular}{|c|c|c|c|c|c|}
\hline Month & $\begin{array}{l}\text { All } \\
\text { (unweighted) }\end{array}$ & $\begin{array}{l}\text { All } \\
\text { (weighted) }\end{array}$ & $\begin{array}{l}\text { Railways } \\
\text { (weighted) }\end{array}$ & $\begin{array}{l}\text { Financials } \\
\text { (weighted) }\end{array}$ & $\begin{array}{l}\text { Other } \\
\text { (weighted) }\end{array}$ \\
\hline $1864: 10$ & 100.0 & 100.0 & 100.0 & 100.0 & 100.0 \\
\hline 1864:11 & 100.6 & 103.0 & 104.0 & 102.3 & 99.6 \\
\hline 1864:12 & 101.5 & 104.1 & 106.5 & 101.8 & 99.7 \\
\hline 1865:1 & 102.7 & 104.1 & 105.1 & 102.7 & 103.2 \\
\hline $1865: 2$ & 101.3 & 103.0 & 103.9 & 101.2 & 103.8 \\
\hline $1865: 3$ & 99.8 & 101.6 & 103.8 & 97.5 & 103.6 \\
\hline $1865: 4$ & 99.8 & 101.8 & 104.2 & 97.5 & 103.3 \\
\hline 1865:5 & 99.5 & 102.7 & 106.5 & 96.6 & 103.2 \\
\hline $1865: 6$ & 99.1 & 102.0 & 106.2 & 94.8 & 104.0 \\
\hline $1865: 7$ & 97.1 & 101.0 & 105.1 & 95.5 & 97.3 \\
\hline $1865: 8$ & 96.2 & 100.1 & 104.8 & 95.1 & 92.3 \\
\hline $1865: 9$ & 96.4 & 100.1 & 101.4 & 99.7 & 95.2 \\
\hline $1865: 10$ & 94.8 & 100.1 & 101.4 & 99.2 & 96.8 \\
\hline 1865:11 & 97.7 & 102.1 & 101.6 & 102.2 & 104.8 \\
\hline 1865:12 & 100.2 & 102.4 & 102.3 & 102.7 & 102.1 \\
\hline 1866:1 & 99.5 & 101.4 & 102.6 & 100.0 & 99.7 \\
\hline $1866: 2$ & 99.6 & 100.5 & 101.0 & 99.3 & 102.0 \\
\hline $1866: 3$ & 98.9 & 100.2 & 100.5 & 98.5 & 104.0 \\
\hline $1866: 4$ & 98.8 & 100.1 & 100.3 & 99.0 & 103.1 \\
\hline 1866:5 & 96.4 & 98.3 & 98.2 & 97.3 & 102.2 \\
\hline 1866:6 & 100.0 & 97.4 & 97.3 & 96.9 & 99.2 \\
\hline 1866:7 & 99.6 & 97.6 & 96.5 & 98.5 & 101.0 \\
\hline $1866: 8$ & 100.0 & 98.0 & 97.3 & 96.4 & 106.6 \\
\hline $1866: 9$ & 100.6 & 99.4 & 99.2 & 97.1 & 106.6 \\
\hline $1866: 10$ & 99.9 & 98.9 & 99.0 & 96.8 & 104.2 \\
\hline 1866:11 & 106.7 & 101.8 & 100.0 & 103.5 & 105.1 \\
\hline $1866: 12$ & 105.2 & 101.5 & 100.0 & 103.0 & 104.0 \\
\hline 1867:1 & 107.3 & 102.6 & 100.3 & 104.7 & 107.8 \\
\hline $1867: 2$ & 107.4 & 101.8 & 99.9 & 103.1 & 107.2 \\
\hline $1867: 3$ & 107.1 & 101.3 & 99.2 & 103.1 & 106.4 \\
\hline $1867: 4$ & 107.0 & 101.4 & 99.4 & 103.1 & 106.2 \\
\hline $1867: 5$ & 113.1 & 102.6 & 100.3 & 103.4 & 111.4 \\
\hline $1867: 6$ & 113.9 & 102.4 & 97.7 & 107.4 & 111.2 \\
\hline 1867:7 & 113.4 & 103.1 & 99.2 & 107.2 & 110.0 \\
\hline $1867: 8$ & 113.2 & 104.4 & 100.3 & 108.2 & 113.1 \\
\hline $1867: 9$ & 112.2 & 103.5 & 99.3 & 107.3 & 112.2 \\
\hline $1867: 10$ & 114.6 & 104.0 & 100.2 & 107.6 & 111.2 \\
\hline 1867:11 & 112.6 & 104.0 & 100.3 & 108.4 & 108.6 \\
\hline $1867: 12$ & 112.9 & 104.2 & 100.6 & 108.5 & 108.6 \\
\hline 1868:1 & 112.6 & 103.9 & 100.1 & 108.8 & 108.1 \\
\hline 1868:2 & 113.1 & 104.1 & 100.6 & 108.1 & 109.2 \\
\hline $1868: 3$ & 114.0 & 102.4 & 97.4 & 108.5 & 109.1 \\
\hline 1868:4 & 114.9 & 104.0 & 100.2 & 108.4 & 108.8 \\
\hline
\end{tabular}




\begin{tabular}{|c|c|c|c|c|c|}
\hline 1868:5 & 116.2 & 104.6 & 100.9 & 109.0 & 109.3 \\
\hline 1868:6 & 116.0 & 105.0 & 100.6 & 110.7 & 109.1 \\
\hline 1868:7 & 115.3 & 104.8 & 101.0 & 109.9 & 107.9 \\
\hline 1868:8 & 115.4 & 104.2 & 100.0 & 109.6 & 107.9 \\
\hline 1868:9 & 115.7 & 104.5 & 100.6 & 109.9 & 107.3 \\
\hline 1868:10 & 115.9 & 104.1 & 99.8 & 110.1 & 107.4 \\
\hline 1868:11 & 114.7 & 103.5 & 98.8 & 110.2 & 106.1 \\
\hline 1868:12 & 114.2 & 103.4 & 98.3 & 110.8 & 106.3 \\
\hline 1869:1 & 114.6 & 103.6 & 97.8 & 112.6 & 105.3 \\
\hline 1869:2 & 114.7 & 102.4 & 96.5 & 110.9 & 106.7 \\
\hline 1869:3 & 113.6 & 102.1 & 96.5 & 110.1 & 106.4 \\
\hline 1869:4 & 113.4 & 102.1 & 97.2 & 109.1 & 104.8 \\
\hline 1869:5 & 113.3 & 101.9 & 97.2 & 109.0 & 102.5 \\
\hline 1869:6 & 111.8 & 101.3 & 96.2 & 109.4 & 101.4 \\
\hline 1869:7 & 111.8 & 100.8 & 94.8 & 110.6 & 101.4 \\
\hline 1869:8 & 112.7 & 102.2 & 96.6 & 111.2 & 102.1 \\
\hline 1869:9 & 112.8 & 102.8 & 96.5 & 112.9 & 103.2 \\
\hline 1869:10 & 114.0 & 102.9 & 95.7 & 113.8 & 105.7 \\
\hline 1869:11 & 113.7 & 103.3 & 96.4 & 114.3 & 103.9 \\
\hline 1869:12 & 114.6 & 102.3 & 94.8 & 114.6 & 102.2 \\
\hline 1870:1 & 116.1 & 104.4 & 97.4 & 116.5 & 102.2 \\
\hline $1870: 2$ & 118.1 & 106.4 & 100.5 & 116.7 & 103.0 \\
\hline 1870:3 & 119.3 & 106.7 & 100.3 & 118.2 & 101.9 \\
\hline $1870: 4$ & 118.8 & 109.0 & 102.8 & 121.1 & 100.6 \\
\hline 1870:5 & 122.2 & 110.0 & 102.8 & 123.2 & 103.4 \\
\hline 1870:6 & 123.3 & 110.3 & 102.2 & 125.4 & 103.5 \\
\hline 1870:7 & 125.3 & 108.9 & 101.2 & 122.6 & 104.1 \\
\hline 1870:8 & 125.8 & 108.2 & 100.1 & 122.5 & 104.0 \\
\hline 1870:9 & 124.6 & 108.7 & 100.3 & 123.6 & 104.0 \\
\hline 1870:10 & 125.2 & 110.3 & 102.5 & 124.4 & 104.8 \\
\hline 1870:11 & 125.5 & 109.6 & 101.8 & 123.9 & 103.6 \\
\hline 1870:12 & 127.9 & 111.0 & 103.1 & 125.6 & 104.5 \\
\hline 1871:1 & 130.9 & 112.6 & 103.5 & 129.3 & 105.9 \\
\hline 1871:2 & 133.7 & 112.8 & 103.6 & 129.7 & 106.3 \\
\hline 1871:3 & 138.1 & 113.3 & 104.2 & 129.8 & 107.8 \\
\hline 1871:4 & 139.6 & 114.3 & 104.8 & 131.7 & 107.6 \\
\hline 1871:5 & 142.3 & 115.2 & 105.1 & 133.8 & 107.9 \\
\hline 1871:6 & 142.5 & 115.8 & 105.5 & 134.6 & 109.3 \\
\hline 1871:7 & 147.7 & 119.3 & 109.6 & 137.7 & 109.3 \\
\hline 1871:8 & 152.8 & 119.2 & 108.9 & 137.6 & 114.1 \\
\hline 1871:9 & 160.1 & 122.2 & 110.3 & 143.0 & 117.5 \\
\hline 1871:10 & 161.5 & 123.8 & 111.8 & 145.1 & 118.1 \\
\hline 1871:11 & 164.4 & 127.1 & 114.4 & 150.6 & 117.3 \\
\hline 1871:12 & 171.6 & 127.4 & 113.4 & 152.5 & 120.8 \\
\hline 1872:1 & 171.6 & 127.8 & 112.8 & 153.9 & 123.8 \\
\hline $1872: 2$ & 174.1 & 129.9 & 113.2 & 158.0 & 130.0 \\
\hline
\end{tabular}




\begin{tabular}{|c|c|c|c|c|c|}
\hline $1872: 3$ & 179.3 & 129.4 & 113.8 & 156.0 & 127.9 \\
\hline $1872: 4$ & 177.5 & 128.9 & 113.9 & 155.1 & 124.3 \\
\hline 1872:5 & 176.6 & 129.8 & 115.0 & 155.6 & 124.9 \\
\hline $1872: 6$ & 182.3 & 132.0 & 117.2 & 157.1 & 129.5 \\
\hline 1872:7 & 181.8 & 132.2 & 117.8 & 157.1 & 127.6 \\
\hline $1872: 8$ & 180.2 & 133.0 & 120.7 & 154.6 & 125.4 \\
\hline 1872:9 & 185.1 & 132.7 & 120.7 & 154.2 & 123.6 \\
\hline 1872:10 & 183.1 & 131.7 & 120.2 & 152.4 & 122.0 \\
\hline 1872:11 & 182.1 & 131.8 & 120.1 & 153.2 & 121.1 \\
\hline 1872:12 & 185.3 & 134.6 & 121.5 & 158.9 & 122.1 \\
\hline 1873:1 & 185.9 & 135.1 & 121.7 & 160.1 & 122.0 \\
\hline $1873: 2$ & 186.7 & 134.9 & 121.6 & 159.2 & 123.1 \\
\hline $1873: 3$ & 187.5 & 133.9 & 120.8 & 157.8 & 122.8 \\
\hline $1873: 4$ & 187.3 & 134.4 & 121.7 & 157.9 & 122.0 \\
\hline 1873:5 & 187.1 & 135.0 & 122.6 & 158.5 & 120.3 \\
\hline $1873: 6$ & 185.2 & 134.0 & 121.0 & 159.0 & 117.8 \\
\hline 1873:7 & 185.8 & 134.1 & 120.7 & 159.4 & 119.8 \\
\hline $1873: 8$ & 187.1 & 134.3 & 121.0 & 159.2 & 121.1 \\
\hline 1873:9 & 187.8 & 134.0 & 121.4 & 157.2 & 121.8 \\
\hline 1873:10 & 185.9 & 133.6 & 121.6 & 155.8 & 120.5 \\
\hline 1873:11 & 184.2 & 134.3 & 122.7 & 156.7 & 117.6 \\
\hline 1873:12 & 184.3 & 134.9 & 123.1 & 157.5 & 118.6 \\
\hline 1874:1 & 180.8 & 134.1 & 124.0 & 153.1 & 119.0 \\
\hline $1874: 2$ & 180.4 & 134.4 & 124.1 & 153.7 & 119.7 \\
\hline $1874: 3$ & 180.3 & 136.3 & 124.4 & 159.6 & 117.3 \\
\hline $1874: 4$ & 179.8 & 136.1 & 124.4 & 158.5 & 118.2 \\
\hline $1874: 5$ & 180.2 & 136.0 & 126.2 & 154.7 & 118.1 \\
\hline 1874:6 & 180.4 & 134.1 & 124.6 & 151.7 & 117.5 \\
\hline 1874:7 & 180.5 & 136.3 & 126.8 & 154.0 & 119.4 \\
\hline $1874: 8$ & 179.3 & 135.7 & 126.6 & 153.0 & 117.5 \\
\hline 1874:9 & 178.7 & 136.3 & 127.2 & 153.2 & 119.8 \\
\hline $1874: 10$ & 179.6 & 137.6 & 128.5 & 154.5 & 121.2 \\
\hline 1874:11 & 179.8 & 138.5 & 129.3 & 155.6 & 122.0 \\
\hline $1874: 12$ & 182.5 & 137.1 & 126.6 & 156.1 & 122.4 \\
\hline 1875:1 & 183.6 & 138.4 & 126.5 & 159.1 & 126.3 \\
\hline $1875: 2$ & 182.0 & 137.7 & 125.1 & 159.1 & 128.4 \\
\hline $1875: 3$ & 180.6 & 137.3 & 125.4 & 157.6 & 127.1 \\
\hline $1875: 4$ & 180.7 & 138.0 & 125.5 & 158.3 & 131.1 \\
\hline $1875: 5$ & 181.8 & 139.4 & 126.6 & 160.1 & 132.9 \\
\hline $1875: 6$ & 179.5 & 139.4 & 125.7 & 161.4 & 133.7 \\
\hline $1875: 7$ & 182.6 & 140.3 & 126.5 & 162.7 & 134.1 \\
\hline $1875: 8$ & 189.4 & 142.1 & 127.3 & 166.3 & 136.8 \\
\hline $1875: 9$ & 190.8 & 142.7 & 127.4 & 167.5 & 138.1 \\
\hline $1875: 10$ & 192.6 & 143.7 & 127.4 & 169.9 & 140.4 \\
\hline 1875:11 & 194.9 & 144.6 & 128.0 & 171.6 & 140.8 \\
\hline $1875: 12$ & 197.0 & 144.6 & 127.3 & 172.6 & 141.1 \\
\hline
\end{tabular}




\begin{tabular}{|c|c|c|c|c|c|}
\hline 1876:1 & 200.8 & 147.3 & 129.9 & 175.5 & 144.0 \\
\hline $1876: 2$ & 201.8 & 148.6 & 130.3 & 178.5 & 144.1 \\
\hline 1876:3 & 204.1 & 149.1 & 130.1 & 180.1 & 145.5 \\
\hline $1876: 4$ & 205.6 & 150.2 & 130.8 & 182.4 & 145.5 \\
\hline 1876:5 & 206.9 & 149.3 & 128.7 & 183.3 & 145.2 \\
\hline $1876: 6$ & 208.4 & 149.0 & 128.4 & 182.2 & 148.0 \\
\hline 1876:7 & 212.8 & 153.0 & 130.3 & 190.0 & 151.7 \\
\hline $1876: 8$ & 215.8 & 154.6 & 131.5 & 191.6 & 156.0 \\
\hline 1876:9 & 218.4 & 154.9 & 132.1 & 191.2 & 157.3 \\
\hline 1876:10 & 217.4 & 154.2 & 130.5 & 191.3 & 159.1 \\
\hline 1876:11 & 217.6 & 155.7 & 132.1 & 193.4 & 158.2 \\
\hline $1876: 12$ & 217.5 & 154.9 & 131.3 & 191.9 & 159.6 \\
\hline $1877: 1$ & 219.2 & 157.2 & 132.5 & 196.2 & 161.6 \\
\hline 1877:2 & 221.5 & 158.4 & 133.0 & 198.4 & 163.7 \\
\hline $1877: 3$ & 225.6 & 158.5 & 133.1 & 197.9 & 164.9 \\
\hline $1877: 4$ & 226.3 & 157.6 & 133.3 & 195.4 & 162.8 \\
\hline 1877:5 & 224.8 & 156.4 & 132.9 & 193.1 & 160.5 \\
\hline $1877: 6$ & 226.6 & 158.0 & 133.0 & 196.9 & 163.8 \\
\hline 1877:7 & 227.5 & 158.4 & 133.5 & 197.8 & 162.0 \\
\hline $1877: 8$ & 229.0 & 158.4 & 133.1 & 198.3 & 162.8 \\
\hline 1877:9 & 227.6 & 157.9 & 133.7 & 196.0 & 161.4 \\
\hline 1877:10 & 227.5 & 158.0 & 133.7 & 196.7 & 160.5 \\
\hline 1877:11 & 226.1 & 158.8 & 134.6 & 197.4 & 160.7 \\
\hline $1877: 12$ & 226.8 & 158.5 & 134.1 & 197.6 & 160.3 \\
\hline 1878:1 & 224.2 & 158.2 & 133.9 & 196.7 & 161.5 \\
\hline 1878:2 & 223.3 & 157.7 & 133.2 & 196.9 & 160.1 \\
\hline 1878:3 & 221.5 & 157.6 & 133.4 & 196.4 & 159.0 \\
\hline 1878:4 & 220.7 & 156.9 & 132.7 & 196.2 & 157.3 \\
\hline 1878:5 & 220.4 & 157.2 & 133.5 & 195.9 & 156.5 \\
\hline 1878:6 & 225.9 & 158.6 & 134.4 & 198.3 & 157.5 \\
\hline 1878:7 & 223.4 & 158.3 & 134.4 & 197.9 & 156.3 \\
\hline $1878: 8$ & 223.0 & 157.9 & 133.6 & 197.7 & 157.0 \\
\hline 1878:9 & 216.8 & 155.4 & 133.2 & 191.6 & 153.8 \\
\hline 1878:10 & 209.6 & 151.8 & 130.4 & 188.5 & 144.9 \\
\hline 1878:11 & 207.7 & 149.9 & 127.7 & 185.2 & 150.6 \\
\hline 1878:12 & 202.0 & 146.4 & 123.6 & 183.1 & 146.7 \\
\hline 1879:1 & 203.6 & 148.2 & 125.7 & 183.3 & 151.1 \\
\hline 1879:2 & 198.9 & 146.7 & 124.2 & 181.2 & 151.4 \\
\hline 1879:3 & 195.3 & 143.0 & 123.8 & 170.6 & 149.6 \\
\hline 1879:4 & 194.5 & 143.0 & 122.7 & 173.0 & 148.5 \\
\hline 1879:5 & 191.6 & 142.7 & 124.0 & 169.5 & 148.3 \\
\hline 1879:6 & 189.5 & 140.6 & 121.8 & 167.9 & 145.8 \\
\hline 1879:7 & 187.6 & 139.6 & 120.9 & 166.8 & 144.6 \\
\hline 1879:8 & 184.3 & 139.0 & 119.4 & 166.7 & 146.7 \\
\hline 1879:9 & 182.9 & 135.3 & 116.5 & 160.6 & 146.4 \\
\hline 1879:10 & 189.5 & 137.3 & 118.1 & 162.7 & 149.8 \\
\hline
\end{tabular}




\begin{tabular}{|c|c|c|c|c|c|}
\hline 1879:11 & 194.2 & 142.7 & 121.8 & 170.9 & 155.8 \\
\hline 1879:12 & 194.8 & 141.3 & 120.5 & 169.3 & 154.1 \\
\hline 1880:1 & 199.1 & 144.1 & 120.5 & 177.3 & 155.7 \\
\hline $1880: 2$ & 201.0 & 144.4 & 120.7 & 177.8 & 156.3 \\
\hline 1880:3 & 202.6 & 143.8 & 121.3 & 174.4 & 157.9 \\
\hline $1880: 4$ & 202.0 & 145.2 & 121.3 & 178.8 & 157.1 \\
\hline 1880:5 & 201.1 & 146.3 & 121.8 & 180.3 & 159.7 \\
\hline 1880:6 & 200.6 & 145.6 & 121.2 & 179.7 & 158.9 \\
\hline 1880:7 & 202.8 & 146.4 & 121.5 & 181.1 & 160.2 \\
\hline $1880: 8$ & 199.3 & 146.7 & 121.7 & 181.8 & 160.0 \\
\hline 1880:9 & 199.5 & 147.2 & 122.9 & 181.1 & 160.2 \\
\hline $1880: 10$ & 199.6 & 145.5 & 122.3 & 176.8 & 160.0 \\
\hline 1880:11 & 197.4 & 144.0 & 122.3 & 174.3 & 154.0 \\
\hline 1880:12 & 199.0 & 144.1 & 122.1 & 173.5 & 157.4 \\
\hline 1881:1 & 196.7 & 144.3 & 122.6 & 174.6 & 153.5 \\
\hline 1881:2 & 193.1 & 143.7 & 122.5 & 173.4 & 152.1 \\
\hline 1881:3 & 191.3 & 142.5 & 122.0 & 170.9 & 151.4 \\
\hline $1881: 4$ & 192.6 & 143.2 & 124.9 & 168.4 & 149.9 \\
\hline 1881:5 & 191.1 & 143.3 & 125.3 & 168.1 & 149.3 \\
\hline 1881:6 & 189.1 & 142.4 & 123.8 & 168.6 & 147.8 \\
\hline 1881:7 & 188.8 & 142.9 & 124.6 & 168.4 & 148.5 \\
\hline 1881:8 & 187.3 & 142.4 & 124.2 & 167.1 & 148.9 \\
\hline 1881:9 & 195.9 & 141.8 & 124.0 & 165.6 & 149.8 \\
\hline $1881: 10$ & 194.6 & 140.9 & 124.0 & 163.1 & 148.3 \\
\hline 1881:11 & 195.0 & 142.5 & 124.8 & 166.7 & 148.8 \\
\hline 1881:12 & 193.8 & 141.0 & 124.4 & 162.5 & 148.3 \\
\hline 1882:1 & 196.0 & 142.2 & 124.1 & 166.3 & 150.4 \\
\hline $1882: 2$ & 193.0 & 142.5 & 124.0 & 167.8 & 149.5 \\
\hline $1882: 3$ & 194.3 & 141.5 & 123.0 & 166.5 & 149.1 \\
\hline $1882: 4$ & 194.1 & 143.0 & 124.3 & 168.9 & 149.2 \\
\hline 1882:5 & 194.0 & 143.1 & 124.2 & 169.5 & 148.5 \\
\hline 1882:6 & 193.6 & 142.4 & 123.2 & 169.4 & 147.8 \\
\hline 1882:7 & 192.0 & 141.9 & 123.0 & 168.3 & 147.2 \\
\hline $1882: 8$ & 194.2 & 144.0 & 124.1 & 172.7 & 148.5 \\
\hline 1882:9 & 195.6 & 144.7 & 125.0 & 172.8 & 149.6 \\
\hline 1882:10 & 196.1 & 144.7 & 125.5 & 172.8 & 147.8 \\
\hline 1882:11 & 196.3 & 144.9 & 125.3 & 172.6 & 150.1 \\
\hline 1882:12 & 191.9 & 144.2 & 124.5 & 172.6 & 148.7 \\
\hline 1883:1 & 191.4 & 145.0 & 124.7 & 175.2 & 148.1 \\
\hline 1883:2 & 190.8 & 145.0 & 125.1 & 174.9 & 146.6 \\
\hline $1883: 3$ & 188.6 & 144.9 & 125.6 & 173.1 & 148.1 \\
\hline $1883: 4$ & 189.0 & 147.2 & 128.1 & 176.3 & 147.2 \\
\hline 1883:5 & 184.7 & 147.4 & 128.4 & 176.7 & 147.1 \\
\hline 1883:6 & 183.0 & 146.9 & 127.7 & 176.3 & 147.2 \\
\hline 1883:7 & 186.6 & 155.1 & 141.0 & 176.9 & 149.5 \\
\hline 1883:8 & 186.2 & 151.9 & 137.1 & 173.2 & 149.7 \\
\hline
\end{tabular}




\begin{tabular}{|c|c|c|c|c|c|}
\hline $1883: 9$ & 181.9 & 151.6 & 136.5 & 172.6 & 151.2 \\
\hline 1883:10 & 180.4 & 151.2 & 137.0 & 171.0 & 150.2 \\
\hline 1883:11 & 179.8 & 151.7 & 138.0 & 171.8 & 147.5 \\
\hline 1883:12 & 179.0 & 151.4 & 137.9 & 171.0 & 148.4 \\
\hline 1884:1 & 181.0 & 151.7 & 138.3 & 170.3 & 149.9 \\
\hline 1884:2 & 180.9 & 151.2 & 137.4 & 170.6 & 149.5 \\
\hline 1884:3 & 179.6 & 150.3 & 137.9 & 166.7 & 149.6 \\
\hline $1884: 4$ & 179.9 & 149.8 & 137.8 & 165.2 & 149.6 \\
\hline 1884:5 & 178.9 & 151.1 & 139.2 & 167.0 & 149.3 \\
\hline 1884:6 & 177.9 & 149.9 & 137.9 & 165.4 & 149.5 \\
\hline 1884:7 & 177.1 & 149.4 & 137.4 & 164.4 & 150.1 \\
\hline $1884: 8$ & 175.4 & 149.4 & 136.9 & 164.9 & 151.1 \\
\hline 1884:9 & 178.0 & 151.0 & 137.8 & 167.2 & 153.1 \\
\hline 1884:10 & 176.4 & 151.6 & 139.7 & 166.3 & 152.4 \\
\hline 1884:11 & 181.3 & 150.3 & 138.3 & 164.0 & 153.1 \\
\hline 1884:12 & 183.9 & 151.1 & 138.3 & 165.3 & 156.0 \\
\hline 1885:1 & 185.5 & 152.2 & 139.6 & 166.5 & 155.7 \\
\hline $1885: 2$ & 185.1 & 150.1 & 138.0 & 162.6 & 155.8 \\
\hline $1885: 3$ & 183.3 & 148.7 & 136.6 & 161.5 & 154.3 \\
\hline $1885: 4$ & 181.4 & 147.5 & 135.7 & 159.7 & 152.8 \\
\hline 1885:5 & 181.6 & 148.8 & 137.3 & 160.3 & 154.7 \\
\hline $1885: 6$ & 181.6 & 148.2 & 136.2 & 159.0 & 157.2 \\
\hline 1885:7 & 179.9 & 145.8 & 132.6 & 157.9 & 156.6 \\
\hline $1885: 8$ & 179.4 & 145.4 & 132.4 & 157.0 & 156.4 \\
\hline $1885: 9$ & 177.7 & 142.9 & 129.6 & 153.0 & 158.7 \\
\hline $1885: 10$ & 174.2 & 140.7 & 127.1 & 150.1 & 158.6 \\
\hline 1885:11 & 182.5 & 141.5 & 127.3 & 152.0 & 159.5 \\
\hline $1885: 12$ & 178.3 & 132.1 & 113.9 & 144.6 & 159.6 \\
\hline 1886:1 & 179.8 & 136.4 & 118.9 & 149.2 & 160.7 \\
\hline 1886:2 & 176.7 & 132.8 & 115.3 & 144.4 & 159.6 \\
\hline $1886: 3$ & 174.2 & 130.1 & 112.1 & 141.8 & 158.7 \\
\hline $1886: 4$ & 172.5 & 128.7 & 111.0 & 140.0 & 157.6 \\
\hline 1886:5 & 170.1 & 127.6 & 110.5 & 138.5 & 154.7 \\
\hline 1886:6 & 169.0 & 127.8 & 110.4 & 139.4 & 154.6 \\
\hline 1886:7 & 172.6 & 132.1 & 113.0 & 147.6 & 156.5 \\
\hline $1886: 8$ & 174.2 & 133.0 & 113.8 & 148.3 & 157.9 \\
\hline 1886:9 & 174.5 & 132.7 & 112.8 & 147.2 & 161.8 \\
\hline $1886: 10$ & 175.5 & 133.1 & 113.0 & 147.9 & 161.6 \\
\hline 1886:11 & 178.7 & 134.9 & 114.9 & 149.7 & 163.2 \\
\hline $1886: 12$ & 177.3 & 135.3 & 116.3 & 149.1 & 162.3 \\
\hline $1887: 1$ & 176.1 & 135.5 & 115.5 & 151.0 & 162.2 \\
\hline $1887: 2$ & 178.4 & 134.9 & 113.9 & 152.3 & 161.3 \\
\hline $1887: 3$ & 177.9 & 134.5 & 113.7 & 151.2 & 161.8 \\
\hline $1887: 4$ & 180.5 & 136.3 & 114.0 & 155.8 & 162.0 \\
\hline 1887:5 & 185.5 & 138.7 & 116.8 & 158.1 & 162.9 \\
\hline 1887:6 & 188.3 & 140.6 & 117.9 & 161.5 & 164.7 \\
\hline
\end{tabular}




\begin{tabular}{|c|c|c|c|c|c|}
\hline 1887:7 & 189.3 & 139.5 & 116.2 & 160.5 & 165.3 \\
\hline $1887: 8$ & 185.2 & 137.6 & 113.7 & 159.9 & 163.2 \\
\hline 1887:9 & 183.4 & 134.5 & 111.6 & 153.9 & 163.2 \\
\hline $1887: 10$ & 182.5 & 135.5 & 113.6 & 154.5 & 161.3 \\
\hline 1887:11 & 182.9 & 136.4 & 114.8 & 155.0 & 160.9 \\
\hline $1887: 12$ & 183.2 & 136.8 & 115.7 & 154.7 & 161.4 \\
\hline 1888:1 & 184.9 & 138.3 & 114.6 & 160.2 & 163.0 \\
\hline 1888:2 & 187.0 & 139.2 & 116.3 & 159.2 & 164.6 \\
\hline 1888:3 & 187.7 & 143.3 & 120.4 & 164.1 & 166.6 \\
\hline 1888:4 & 188.3 & 144.5 & 122.8 & 164.0 & 166.0 \\
\hline 1888:5 & 190.5 & 144.9 & 121.2 & 167.5 & 167.0 \\
\hline 1888:6 & 190.9 & 145.9 & 122.8 & 167.4 & 167.8 \\
\hline 1888:7 & 192.1 & 146.6 & 121.5 & 171.7 & 167.6 \\
\hline 1888:8 & 193.3 & 146.4 & 122.1 & 169.9 & 168.0 \\
\hline 1888:9 & 196.7 & 148.6 & 122.4 & 174.9 & 170.5 \\
\hline 1888:10 & 195.8 & 149.9 & 125.2 & 174.4 & 169.8 \\
\hline 1888:11 & 198.4 & 152.3 & 126.9 & 178.4 & 171.3 \\
\hline 1888:12 & 199.0 & 153.1 & 127.7 & 179.8 & 170.2 \\
\hline 1889:1 & 201.6 & 155.5 & 128.1 & 185.8 & 171.7 \\
\hline 1889:2 & 204.9 & 156.3 & 127.9 & 187.3 & 174.1 \\
\hline 1889:3 & 203.0 & 154.0 & 126.1 & 183.4 & 174.2 \\
\hline 1889:4 & 206.1 & 155.2 & 126.5 & 186.1 & 174.6 \\
\hline 1889:5 & 206.9 & 156.3 & 128.0 & 187.1 & 174.8 \\
\hline 1889:6 & 208.6 & 157.3 & 129.5 & 186.4 & 176.3 \\
\hline 1889:7 & 208.6 & 157.9 & 128.3 & 190.5 & 176.7 \\
\hline 1889:8 & 210.8 & 160.7 & 129.0 & 195.9 & 181.6 \\
\hline 1889:9 & 212.1 & 160.8 & 131.0 & 191.7 & 183.4 \\
\hline 1889:10 & 211.1 & 160.8 & 131.1 & 192.0 & 182.2 \\
\hline 1889:11 & 211.4 & 161.6 & 132.8 & 192.3 & 180.1 \\
\hline 1889:12 & 212.1 & 161.6 & 133.4 & 189.5 & 183.6 \\
\hline 1890:1 & 215.2 & 161.2 & 132.2 & 189.8 & 184.5 \\
\hline 1890:2 & 213.8 & 160.2 & 132.1 & 186.8 & 184.5 \\
\hline 1890:3 & 212.2 & 158.9 & 132.4 & 182.6 & 183.4 \\
\hline 1890:4 & 212.8 & 158.5 & 132.2 & 181.4 & 183.7 \\
\hline 1890:5 & 214.7 & 161.1 & 134.5 & 185.7 & 183.7 \\
\hline 1890:6 & 215.0 & 161.4 & 135.5 & 184.5 & 184.2 \\
\hline 1890:7 & 214.6 & 159.6 & 134.2 & 182.1 & 182.2 \\
\hline 1890:8 & 212.1 & 159.3 & 134.1 & 181.1 & 182.4 \\
\hline 1890:9 & 207.7 & 158.7 & 133.1 & 180.7 & 183.3 \\
\hline $1890: 10$ & 205.5 & 158.2 & 133.0 & 179.6 & 182.1 \\
\hline 1890:11 & 206.8 & 159.2 & 132.8 & 183.0 & 182.5 \\
\hline 1890:12 & 207.2 & 161.3 & 134.4 & 187.1 & 182.0 \\
\hline 1891:1 & 206.3 & 161.0 & 132.8 & 188.9 & 182.0 \\
\hline 1891:2 & 206.7 & 162.5 & 134.0 & 190.6 & 184.3 \\
\hline 1891:3 & 209.4 & 163.7 & 134.5 & 192.4 & 186.9 \\
\hline 1891:4 & 210.6 & 163.6 & 134.6 & 191.6 & 187.0 \\
\hline
\end{tabular}




\begin{tabular}{|c|c|c|c|c|c|}
\hline 1891:5 & 211.9 & 163.6 & 134.6 & 192.2 & 185.8 \\
\hline 1891:6 & 210.5 & 164.0 & 135.3 & 192.5 & 185.4 \\
\hline 1891:7 & 211.9 & 163.9 & 134.6 & 193.4 & 185.7 \\
\hline 1891:8 & 211.2 & 164.5 & 135.5 & 193.4 & 186.2 \\
\hline 1891:9 & 210.2 & 163.9 & 135.0 & 191.9 & 186.7 \\
\hline $1891: 10$ & 209.7 & 163.2 & 134.9 & 190.4 & 185.6 \\
\hline 1891:11 & 208.8 & 162.8 & 135.9 & 189.2 & 181.7 \\
\hline 1891:12 & 209.3 & 164.4 & 137.5 & 191.9 & 181.0 \\
\hline 1892:1 & 210.0 & 165.6 & 136.4 & 196.0 & 184.6 \\
\hline 1892:2 & 209.9 & 163.7 & 135.4 & 191.0 & 185.5 \\
\hline 1892:3 & 208.1 & 163.2 & 134.9 & 190.3 & 185.6 \\
\hline 1892:4 & 206.2 & 162.8 & 134.7 & 190.1 & 184.2 \\
\hline 1892:5 & 206.2 & 162.5 & 134.4 & 189.0 & 185.3 \\
\hline 1892:6 & 205.0 & 158.0 & 130.3 & 182.5 & 184.1 \\
\hline 1892:7 & 204.7 & 161.0 & 132.2 & 188.7 & 183.7 \\
\hline 1892:8 & 203.5 & 161.8 & 132.6 & 189.4 & 186.3 \\
\hline 1892:9 & 200.2 & 160.8 & 131.8 & 186.9 & 187.1 \\
\hline 1892:10 & 196.7 & 163.0 & 134.2 & 190.0 & 186.7 \\
\hline 1892:11 & 194.9 & 162.8 & 134.6 & 190.3 & 183.8 \\
\hline 1892:12 & 195.3 & 164.1 & 135.6 & 191.6 & 185.4 \\
\hline 1893:1 & 196.9 & 164.6 & 133.0 & 194.6 & 192.1 \\
\hline 1893:2 & 197.1 & 159.3 & 128.8 & 183.5 & 194.4 \\
\hline 1893:3 & 187.6 & 155.3 & 125.3 & 183.6 & 180.4 \\
\hline 1893:4 & 185.6 & 155.9 & 124.3 & 188.2 & 178.7 \\
\hline 1893:5 & 188.0 & 159.1 & 127.6 & 190.3 & 182.7 \\
\hline 1893:6 & 188.7 & 160.7 & 128.9 & 193.5 & 182.0 \\
\hline 1893:7 & 188.0 & 159.2 & 127.2 & 192.1 & 181.4 \\
\hline 1893:8 & 185.7 & 159.4 & 127.1 & 192.0 & 182.9 \\
\hline 1893:9 & 185.3 & 160.2 & 128.3 & 192.3 & 183.5 \\
\hline 1893:10 & 183.8 & 161.8 & 130.2 & 194.9 & 181.4 \\
\hline 1893:11 & 183.3 & 163.1 & 132.4 & 193.9 & 183.4 \\
\hline 1893:12 & 181.7 & 161.5 & 131.3 & 193.4 & 178.0 \\
\hline 1894:1 & 184.6 & 164.2 & 132.0 & 197.6 & 184.6 \\
\hline 1894:2 & 189.8 & 162.7 & 132.0 & 192.6 & 185.1 \\
\hline 1894:3 & 193.5 & 164.8 & 132.2 & 196.0 & 191.3 \\
\hline 1894:4 & 193.6 & 166.6 & 133.0 & 200.8 & 189.5 \\
\hline 1894:5 & 191.6 & 166.3 & 133.1 & 200.2 & 188.5 \\
\hline 1894:6 & 192.5 & 167.2 & 133.6 & 202.8 & 187.0 \\
\hline 1894:7 & 192.2 & 169.0 & 132.9 & 209.6 & 186.6 \\
\hline 1894:8 & 198.8 & 172.5 & 137.0 & 213.6 & 186.3 \\
\hline 1894:9 & 203.1 & 175.4 & 138.7 & 216.9 & 191.9 \\
\hline 1894:10 & 203.3 & 175.0 & 138.7 & 215.0 & 193.6 \\
\hline 1894:11 & 200.6 & 174.7 & 138.2 & 215.4 & 192.3 \\
\hline 1894:12 & 203.9 & 176.6 & 138.5 & 221.1 & 191.4 \\
\hline 1895:1 & 208.7 & 179.7 & 139.2 & 227.8 & 195.3 \\
\hline $1895: 2$ & 213.8 & 181.6 & 140.5 & 228.2 & 202.7 \\
\hline
\end{tabular}




\begin{tabular}{|c|c|c|c|c|c|}
\hline $1895: 3$ & 213.5 & 181.9 & 141.3 & 226.5 & 204.9 \\
\hline $1895: 4$ & 212.2 & 182.2 & 141.8 & 228.1 & 201.5 \\
\hline 1895:5 & 213.5 & 183.1 & 143.6 & 228.6 & 199.1 \\
\hline 1895:6 & 216.4 & 185.7 & 144.6 & 233.8 & 202.4 \\
\hline 1895:7 & 216.9 & 185.0 & 143.6 & 232.6 & 203.7 \\
\hline $1895: 8$ & 219.0 & 186.0 & 143.9 & 234.1 & 206.1 \\
\hline $1895: 9$ & 221.7 & 190.0 & 144.8 & 241.5 & 213.7 \\
\hline $1895: 10$ & 221.5 & 192.3 & 147.6 & 243.4 & 215.0 \\
\hline 1895:11 & 223.9 & 192.1 & 147.9 & 242.5 & 214.3 \\
\hline 1895:12 & 221.8 & 190.0 & 147.1 & 238.0 & 212.6 \\
\hline 1896:1 & 221.9 & 192.4 & 145.9 & 247.2 & 213.0 \\
\hline 1896:2 & 235.1 & 194.1 & 146.7 & 249.5 & 216.5 \\
\hline 1896:3 & 234.7 & 193.9 & 146.4 & 247.9 & 219.9 \\
\hline 1896:4 & 237.3 & 197.5 & 150.1 & 252.4 & 220.3 \\
\hline 1896:5 & 242.1 & 198.4 & 150.9 & 251.2 & 226.0 \\
\hline 1896:6 & 246.8 & 200.2 & 152.5 & 252.0 & 230.4 \\
\hline 1896:7 & 247.8 & 200.1 & 152.0 & 252.1 & 231.4 \\
\hline $1896: 8$ & 246.7 & 199.3 & 151.6 & 248.1 & 236.1 \\
\hline 1896:9 & 239.7 & 194.6 & 151.7 & 236.8 & 228.1 \\
\hline 1896:10 & 235.5 & 190.6 & 150.0 & 228.1 & 226.0 \\
\hline 1896:11 & 236.2 & 195.2 & 152.3 & 237.0 & 228.8 \\
\hline 1896:12 & 237.6 & 195.1 & 152.8 & 235.8 & 228.9 \\
\hline 1897:1 & 238.3 & 197.6 & 154.8 & 239.3 & 230.7 \\
\hline 1897:2 & 237.6 & 199.0 & 154.7 & 243.0 & 231.8 \\
\hline 1897:3 & 237.8 & 196.6 & 153.2 & 240.3 & 227.8 \\
\hline $1897: 4$ & 236.0 & 195.6 & 152.9 & 238.6 & 225.5 \\
\hline 1897:5 & 236.7 & 196.7 & 153.9 & 240.2 & 225.1 \\
\hline $1897: 6$ & 238.8 & 198.1 & 154.9 & 241.1 & 229.1 \\
\hline 1897:7 & 235.5 & 198.3 & 153.8 & 242.6 & 231.6 \\
\hline 1897:8 & 236.8 & 198.5 & 155.4 & 239.1 & 234.7 \\
\hline 1897:9 & 237.6 & 199.3 & 157.5 & 237.2 & 236.4 \\
\hline 1897:10 & 237.5 & 199.6 & 158.2 & 237.3 & 235.2 \\
\hline 1897:11 & 237.6 & 198.6 & 159.4 & 232.8 & 233.1 \\
\hline $1897: 12$ & 235.8 & 200.9 & 160.1 & 239.4 & 230.1 \\
\hline 1898:1 & 238.8 & 204.5 & 161.9 & 244.1 & 238.7 \\
\hline 1898:2 & 244.6 & 204.5 & 160.4 & 245.2 & 242.8 \\
\hline 1898:3 & 244.9 & 203.8 & 160.8 & 243.8 & 238.3 \\
\hline 1898:4 & 242.5 & 201.0 & 158.7 & 239.2 & 237.5 \\
\hline 1898:5 & 240.9 & 201.4 & 159.2 & 240.6 & 234.7 \\
\hline 1898:6 & 243.4 & 203.1 & 160.7 & 242.9 & 235.4 \\
\hline 1898:7 & 236.3 & 204.5 & 164.6 & 242.4 & 229.2 \\
\hline 1898:8 & 235.3 & 204.8 & 164.1 & 244.8 & 227.7 \\
\hline 1898:9 & 239.1 & 205.5 & 164.9 & 243.5 & 232.8 \\
\hline 1898:10 & 240.7 & 205.2 & 165.3 & 241.6 & 233.2 \\
\hline 1898:11 & 236.7 & 203.7 & 165.6 & 238.4 & 227.8 \\
\hline 1898:12 & 239.1 & 203.4 & 165.0 & 237.9 & 229.6 \\
\hline
\end{tabular}




\begin{tabular}{|c|c|c|c|c|c|}
\hline 1899:1 & 244.4 & 205.3 & 165.9 & 241.6 & 231.1 \\
\hline 1899:2 & 243.7 & 204.7 & 166.4 & 238.1 & 233.0 \\
\hline 1899:3 & 245.3 & 204.5 & 166.8 & 235.6 & 235.9 \\
\hline 1899:4 & 243.9 & 203.5 & 166.6 & 234.2 & 232.5 \\
\hline 1899:5 & 242.4 & 203.0 & 166.6 & 234.6 & 227.1 \\
\hline 1899:6 & 242.7 & 204.4 & 169.0 & 235.2 & 225.8 \\
\hline 1899:7 & 238.2 & 204.0 & 169.4 & 234.6 & 222.4 \\
\hline 1899:8 & 237.9 & 203.9 & 167.2 & 237.3 & 223.7 \\
\hline 1899:9 & 237.7 & 203.8 & 168.6 & 234.6 & 223.8 \\
\hline 1899:10 & 235.2 & 200.9 & 165.9 & 230.8 & 223.0 \\
\hline 1899:11 & 233.6 & 201.9 & 166.0 & 236.2 & 216.5 \\
\hline 1899:12 & 228.9 & 198.0 & 165.6 & 227.1 & 210.7 \\
\hline 1900:1 & 230.3 & 200.8 & 166.0 & 234.3 & 211.7 \\
\hline 1900:2 & 230.4 & 199.6 & 165.0 & 232.2 & 212.0 \\
\hline 1900:3 & 230.3 & 199.3 & 165.4 & 229.3 & 215.7 \\
\hline 1900:4 & 230.8 & 199.3 & 166.2 & 228.3 & 214.3 \\
\hline 1900:5 & 229.7 & 198.3 & 165.8 & 228.2 & 208.8 \\
\hline 1900:6 & 228.9 & 198.1 & 165.4 & 228.7 & 207.5 \\
\hline 1900:7 & 225.9 & 197.3 & 163.8 & 229.1 & 207.2 \\
\hline $1900: 8$ & 221.8 & 194.3 & 163.1 & 223.1 & 202.7 \\
\hline $1900: 9$ & 221.4 & 194.6 & 164.0 & 221.8 & 204.7 \\
\hline 1900:10 & 217.6 & 193.4 & 163.8 & 218.8 & 203.6 \\
\hline 1900:11 & 215.0 & 194.7 & 164.6 & 221.1 & 204.1 \\
\hline 1900:12 & 214.3 & 194.6 & 165.0 & 219.0 & 207.6 \\
\hline 1901:1 & 212.0 & 195.7 & 165.8 & 220.1 & 209.0 \\
\hline 1901:2 & 211.4 & 196.0 & 164.5 & 222.7 & 210.4 \\
\hline 1901:3 & 208.3 & 193.8 & 163.9 & 219.2 & 204.4 \\
\hline 1901:4 & 206.1 & 193.8 & 164.7 & 218.5 & 203.2 \\
\hline 1901:5 & 213.6 & 194.1 & 163.9 & 219.1 & 207.5 \\
\hline 1901:6 & 208.9 & 192.0 & 164.7 & 213.1 & 202.5 \\
\hline 1901:7 & 203.6 & 190.3 & 163.2 & 210.2 & 203.3 \\
\hline 1901:8 & 200.7 & 189.1 & 163.8 & 204.6 & 205.6 \\
\hline 1901:9 & 199.2 & 187.9 & 163.2 & 202.8 & 204.0 \\
\hline $1901: 10$ & 197.1 & 187.8 & 164.9 & 199.6 & 203.1 \\
\hline 1901:11 & 196.5 & 188.3 & 165.2 & 202.0 & 199.3 \\
\hline 1901:12 & 197.3 & 187.1 & 164.4 & 200.5 & 197.5 \\
\hline 1902:1 & 200.2 & 188.0 & 165.4 & 200.9 & 198.9 \\
\hline 1902:2 & 199.5 & 187.7 & 164.7 & 201.2 & 198.6 \\
\hline 1902:3 & 199.6 & 186.3 & 163.3 & 199.4 & 198.5 \\
\hline 1902:4 & 199.6 & 185.8 & 163.0 & 197.8 & 200.3 \\
\hline 1902:5 & 193.8 & 185.4 & 163.3 & 196.5 & 199.2 \\
\hline 1902:6 & 193.9 & 185.5 & 164.4 & 195.4 & 197.6 \\
\hline 1902:7 & 192.8 & 185.6 & 163.5 & 196.7 & 198.7 \\
\hline 1902:8 & 195.3 & 185.5 & 162.7 & 198.7 & 196.9 \\
\hline 1902:9 & 194.0 & 184.9 & 162.0 & 198.1 & 197.2 \\
\hline 1902:10 & 194.8 & 187.3 & 162.4 & 203.7 & 199.3 \\
\hline
\end{tabular}




\begin{tabular}{|c|c|c|c|c|c|}
\hline 1902:11 & 198.2 & 187.0 & 161.6 & 205.1 & 197.4 \\
\hline 1902:12 & 198.0 & 188.2 & 161.5 & 209.9 & 194.0 \\
\hline 1903:1 & 201.4 & 193.3 & 167.0 & 214.4 & 197.3 \\
\hline 1903:2 & 207.5 & 192.6 & 167.9 & 209.5 & 199.9 \\
\hline 1903:3 & 206.5 & 190.2 & 163.6 & 209.2 & 200.9 \\
\hline 1903:4 & 207.0 & 190.5 & 164.5 & 209.1 & 199.9 \\
\hline 1903:5 & 206.9 & 191.6 & 166.4 & 209.6 & 198.8 \\
\hline 1903:6 & 204.0 & 189.9 & 165.3 & 206.9 & 197.4 \\
\hline 1903:7 & 202.3 & 190.9 & 166.8 & 206.8 & 197.9 \\
\hline 1903:8 & 202.7 & 189.1 & 165.0 & 205.4 & 196.3 \\
\hline 1903:9 & 199.6 & 189.3 & 165.4 & 205.2 & 196.3 \\
\hline 1903:10 & 196.6 & 186.7 & 164.4 & 199.6 & 193.9 \\
\hline 1903:11 & 197.6 & 187.8 & 165.3 & 201.2 & 194.6 \\
\hline 1903:12 & 201.2 & 187.7 & 164.7 & 201.8 & 195.5 \\
\hline 1904:1 & 202.6 & 187.1 & 163.9 & 200.6 & 196.6 \\
\hline 1904:2 & 199.6 & 183.9 & 161.9 & 194.3 & 196.4 \\
\hline 1904:3 & 197.6 & 182.5 & 160.1 & 193.8 & 195.2 \\
\hline 1904:4 & 196.0 & 183.3 & 160.3 & 196.7 & 193.9 \\
\hline 1904:5 & 196.6 & 183.5 & 160.9 & 195.4 & 195.1 \\
\hline 1904:6 & 197.2 & 184.2 & 161.1 & 197.8 & 194.1 \\
\hline 1904:7 & 195.5 & 183.6 & 161.0 & 196.5 & 193.4 \\
\hline 1904:8 & 195.7 & 183.3 & 161.3 & 194.1 & 194.9 \\
\hline 1904:9 & 195.5 & 181.8 & 159.7 & 191.4 & 196.6 \\
\hline 1904:10 & 193.8 & 182.9 & 160.6 & 192.7 & 197.7 \\
\hline 1904:11 & 192.2 & 182.2 & 160.5 & 191.0 & 196.7 \\
\hline 1904:12 & 195.1 & 182.6 & 160.5 & 191.4 & 199.0 \\
\hline 1905:1 & 196.4 & 183.5 & 160.0 & 194.5 & 200.8 \\
\hline 1905:2 & 194.9 & 181.6 & 159.7 & 189.9 & 198.4 \\
\hline $1905: 3$ & 194.7 & 181.2 & 158.3 & 190.4 & 200.8 \\
\hline $1905: 4$ & 195.4 & 182.1 & 159.2 & 191.7 & 200.1 \\
\hline $1905: 5$ & 195.5 & 182.4 & 160.5 & 190.7 & 199.0 \\
\hline $1905: 6$ & 193.6 & 182.0 & 159.5 & 191.1 & 199.3 \\
\hline 1905:7 & 200.9 & 181.7 & 158.5 & 191.9 & 200.2 \\
\hline $1905: 8$ & 199.5 & 181.9 & 160.1 & 189.6 & 199.2 \\
\hline $1905: 9$ & 201.4 & 179.9 & 158.7 & 184.9 & 201.5 \\
\hline 1905:10 & 205.0 & 180.5 & 160.5 & 183.5 & 200.9 \\
\hline 1905:11 & 205.0 & 178.2 & 159.0 & 179.9 & 198.4 \\
\hline 1905:12 & 205.5 & 179.1 & 159.7 & 181.7 & 198.5 \\
\hline 1906:1 & 207.9 & 180.0 & 157.8 & 186.7 & 201.6 \\
\hline 1906:2 & 206.0 & 178.5 & 158.6 & 179.4 & 203.2 \\
\hline $1906: 3$ & 206.2 & 178.6 & 159.9 & 177.3 & 202.6 \\
\hline 1906:4 & 205.6 & 178.4 & 160.1 & 177.4 & 200.1 \\
\hline 1906:5 & 208.0 & 178.6 & 160.7 & 175.5 & 203.7 \\
\hline 1906:6 & 207.5 & 179.8 & 161.0 & 178.9 & 202.7 \\
\hline 1906:7 & 209.1 & 181.1 & 160.4 & 182.7 & 206.3 \\
\hline $1906: 8$ & 211.7 & 180.5 & 159.7 & 178.4 & 214.4 \\
\hline
\end{tabular}




\begin{tabular}{|c|c|c|c|c|c|}
\hline $1906: 9$ & 208.6 & 177.8 & 155.9 & 177.8 & 212.6 \\
\hline 1906:10 & 207.3 & 177.0 & 154.4 & 178.8 & 211.0 \\
\hline 1906:11 & 207.3 & 177.1 & 155.0 & 179.1 & 208.2 \\
\hline 1906:12 & 207.6 & 178.9 & 155.2 & 183.4 & 210.7 \\
\hline 1907:1 & 209.5 & 178.8 & 154.2 & 183.7 & 213.5 \\
\hline 1907:2 & 205.2 & 174.3 & 150.0 & 177.6 & 212.7 \\
\hline 1907:3 & 204.0 & 173.4 & 148.4 & 177.7 & 213.1 \\
\hline $1907: 4$ & 202.3 & 172.6 & 147.7 & 178.2 & 209.3 \\
\hline $1907: 5$ & 208.7 & 175.1 & 152.9 & 177.3 & 206.2 \\
\hline $1907: 6$ & 206.7 & 174.2 & 151.5 & 176.6 & 206.9 \\
\hline 1907:7 & 207.8 & 174.3 & 149.4 & 180.7 & 207.6 \\
\hline 1907:8 & 205.5 & 174.1 & 150.5 & 177.1 & 209.0 \\
\hline 1907:9 & 206.6 & 173.0 & 149.6 & 174.3 & 211.0 \\
\hline $1907: 10$ & 204.0 & 171.6 & 148.4 & 173.7 & 208.1 \\
\hline 1907:11 & 200.5 & 170.6 & 147.6 & 173.7 & 203.8 \\
\hline 1907:12 & 200.4 & 171.0 & 147.0 & 176.6 & 202.2 \\
\hline 1908:1 & 203.0 & 173.5 & 149.1 & 179.5 & 204.9 \\
\hline 1908:2 & 202.8 & 173.6 & 151.4 & 175.2 & 204.8 \\
\hline 1908:3 & 201.8 & 173.8 & 150.8 & 177.3 & 204.0 \\
\hline 1908:4 & 201.9 & 173.8 & 151.0 & 178.1 & 201.5 \\
\hline 1908:5 & 200.8 & 173.9 & 151.7 & 178.5 & 197.6 \\
\hline 1908:6 & 201.0 & 175.8 & 154.3 & 179.9 & 196.8 \\
\hline 1908:7 & 200.8 & 175.2 & 154.3 & 177.9 & 196.9 \\
\hline 1908:8 & 201.5 & 173.9 & 153.7 & 174.8 & 197.2 \\
\hline 1908:9 & 200.6 & 173.5 & 154.2 & 171.9 & 198.9 \\
\hline 1908:10 & 197.6 & 172.4 & 154.7 & 169.8 & 193.2 \\
\hline 1908:11 & 198.4 & 173.5 & 156.2 & 170.1 & 193.9 \\
\hline 1908:12 & 200.2 & 174.8 & 156.1 & 172.8 & 197.8 \\
\hline 1909:1 & 202.2 & 174.9 & 154.8 & 173.8 & 202.0 \\
\hline 1909:2 & 201.8 & 174.6 & 154.1 & 172.8 & 205.0 \\
\hline 1909:3 & 202.6 & 176.0 & 155.7 & 174.8 & 203.3 \\
\hline 1909:4 & 203.6 & 176.7 & 156.2 & 176.1 & 202.9 \\
\hline 1909:5 & 205.3 & 177.5 & 157.6 & 176.6 & 201.7 \\
\hline 1909:6 & 206.3 & 178.2 & 157.7 & 178.3 & 201.9 \\
\hline 1909:7 & 206.2 & 176.8 & 155.4 & 178.7 & 201.4 \\
\hline 1909:8 & 207.3 & 178.8 & 157.5 & 180.8 & 202.1 \\
\hline 1909:9 & 207.6 & 178.6 & 156.9 & 180.2 & 204.3 \\
\hline 1909:10 & 210.4 & 179.6 & 156.9 & 183.7 & 203.4 \\
\hline 1909:11 & 209.9 & 178.1 & 156.9 & 179.9 & 201.1 \\
\hline 1909:12 & 209.1 & 177.4 & 155.0 & 181.3 & 200.8 \\
\hline 1910:1 & 212.0 & 181.4 & 157.6 & 188.2 & 202.8 \\
\hline 1910:2 & 209.4 & 179.3 & 157.0 & 183.2 & 200.9 \\
\hline 1910:3 & 208.9 & 179.6 & 157.3 & 183.7 & 201.2 \\
\hline 1910:4 & 209.8 & 178.6 & 156.2 & 182.5 & 201.2 \\
\hline 1910:5 & 210.4 & 178.3 & 155.7 & 183.7 & 197.9 \\
\hline 1910:6 & 217.4 & 180.9 & 156.1 & 184.2 & 214.9 \\
\hline
\end{tabular}




\begin{tabular}{|c|c|c|c|c|c|}
\hline 1910:7 & 217.9 & 180.7 & 156.1 & 183.4 & 215.1 \\
\hline 1910:8 & 217.4 & 180.0 & 155.2 & 183.4 & 213.5 \\
\hline 1910:9 & 215.4 & 179.6 & 154.9 & 181.6 & 216.9 \\
\hline 1910:10 & 219.0 & 181.1 & 157.7 & 181.2 & 216.3 \\
\hline 1910:11 & 216.5 & 179.0 & 156.0 & 179.2 & 213.0 \\
\hline 1910:12 & 216.0 & 180.4 & 155.6 & 184.5 & 210.9 \\
\hline 1911:1 & 217.6 & 180.5 & 153.9 & 187.5 & 212.4 \\
\hline 1911:2 & 216.1 & 177.8 & 152.0 & 182.9 & 211.6 \\
\hline 1911:3 & 213.1 & 176.7 & 148.9 & 184.9 & 212.5 \\
\hline 1911:4 & 210.2 & 175.0 & 146.4 & 184.9 & 210.7 \\
\hline 1911:5 & 211.4 & 176.5 & 149.6 & 183.4 & 211.0 \\
\hline 1911:6 & 211.5 & 178.4 & 150.8 & 187.0 & 210.4 \\
\hline 1911:7 & 212.0 & 178.4 & 150.3 & 188.1 & 210.0 \\
\hline 1911:8 & 210.3 & 175.1 & 148.6 & 181.5 & 209.3 \\
\hline 1911:9 & 208.3 & 173.8 & 146.9 & 180.9 & 208.4 \\
\hline 1911:10 & 204.8 & 170.8 & 145.4 & 175.5 & 206.5 \\
\hline 1911:11 & 201.7 & 168.0 & 143.1 & 171.8 & 205.1 \\
\hline 1911:12 & 202.9 & 167.9 & 141.2 & 174.5 & 206.1 \\
\hline 1912:1 & 203.3 & 167.4 & 138.7 & 177.2 & 206.6 \\
\hline 1912:2 & 200.0 & 168.4 & 142.9 & 173.4 & 203.0 \\
\hline 1912:3 & 198.4 & 166.1 & 139.8 & 172.6 & 202.0 \\
\hline 1912:4 & 199.1 & 168.7 & 142.2 & 176.2 & 200.6 \\
\hline 1912:5 & 198.5 & 166.0 & 140.5 & 171.0 & 201.5 \\
\hline 1912:6 & 198.0 & 166.3 & 141.3 & 171.0 & 200.0 \\
\hline 1912:7 & 194.7 & 161.9 & 137.4 & 166.0 & 197.1 \\
\hline 1912:8 & 194.4 & 160.0 & 134.3 & 165.5 & 198.2 \\
\hline 1912:9 & 196.4 & 163.0 & 136.5 & 168.8 & 203.2 \\
\hline 1912:10 & 195.4 & 160.9 & 135.8 & 164.4 & 201.2 \\
\hline 1912:11 & 194.5 & 159.5 & 133.2 & 165.0 & 201.9 \\
\hline 1912:12 & 195.1 & 159.4 & 132.2 & 166.6 & 201.4 \\
\hline 1913:1 & 196.6 & 160.1 & 130.6 & 170.4 & 204.0 \\
\hline 1913:2 & 195.3 & 159.9 & 132.9 & 166.4 & 201.9 \\
\hline 1913:3 & 193.6 & 159.0 & 130.9 & 167.2 & 201.9 \\
\hline 1913:4 & 194.1 & 158.9 & 131.1 & 167.6 & 198.4 \\
\hline 1913:5 & 194.2 & 158.3 & 131.3 & 165.8 & 197.4 \\
\hline 1913:6 & 192.6 & 157.2 & 129.6 & 165.9 & 197.2 \\
\hline 1913:7 & 191.7 & 157.6 & 131.4 & 164.4 & 194.3 \\
\hline 1913:8 & 190.3 & 156.1 & 130.6 & 162.6 & 191.2 \\
\hline 1913:9 & 189.0 & 154.0 & 128.4 & 162.0 & 185.9 \\
\hline 1913:10 & 187.3 & 152.7 & 127.0 & 160.2 & 187.3 \\
\hline 1913:11 & 185.8 & 152.2 & 127.0 & 159.8 & 183.4 \\
\hline 1913:12 & 185.6 & 152.6 & 127.3 & 160.4 & 183.8 \\
\hline 1914:1 & 188.3 & 156.2 & 128.0 & 169.2 & 184.7 \\
\hline 1914:2 & 192.3 & 159.3 & 131.6 & 169.9 & 189.9 \\
\hline 1914:3 & 189.5 & 156.0 & 130.1 & 164.2 & 186.0 \\
\hline 1914:4 & 189.4 & 157.0 & 130.4 & 165.5 & 189.0 \\
\hline
\end{tabular}




\begin{tabular}{|c|c|c|c|c|c|}
\hline 1914:5 & 192.0 & 158.2 & 131.4 & 166.0 & 193.0 \\
\hline 1914:6 & 190.6 & 158.0 & 132.9 & 164.3 & 188.2 \\
\hline 1914:7 & 190.7 & 155.6 & 130.9 & 161.6 & 186.0 \\
\hline $1914: 8$ & 190.7 & 155.6 & 130.9 & 161.6 & 186.0 \\
\hline 1914:9 & 190.7 & 155.6 & 130.9 & 161.6 & 186.0 \\
\hline $1914: 10$ & 190.7 & 155.6 & 130.9 & 161.6 & 186.0 \\
\hline 1914:11 & 190.7 & 155.6 & 130.9 & 161.6 & 186.0 \\
\hline 1914:12 & 190.7 & 155.6 & 130.9 & 161.6 & 186.0 \\
\hline 1915:1 & 187.5 & 156.8 & 130.4 & 165.9 & 185.7 \\
\hline $1915: 2$ & 183.1 & 151.4 & 125.5 & 158.1 & 188.2 \\
\hline 1915:3 & 180.8 & 153.6 & 127.5 & 161.1 & 186.9 \\
\hline 1915:4 & 179.6 & 153.7 & 128.5 & 160.9 & 182.3 \\
\hline 1915:5 & 179.5 & 153.4 & 128.7 & 159.8 & 182.3 \\
\hline 1915:6 & 178.4 & 150.9 & 127.0 & 156.3 & 180.0 \\
\hline 1915:7 & 170.0 & 147.1 & 123.1 & 154.7 & 171.5 \\
\hline 1915:8 & 167.0 & 141.9 & 118.7 & 148.5 & 168.4 \\
\hline 1915:9 & 165.1 & 140.9 & 116.8 & 148.8 & 168.2 \\
\hline $1915: 10$ & 163.4 & 138.5 & 114.3 & 146.7 & 167.4 \\
\hline 1915:11 & 161.6 & 135.6 & 111.3 & 144.2 & 166.1 \\
\hline 1915:12 & 162.1 & 136.4 & 112.8 & 143.4 & 167.3 \\
\hline 1916:1 & 163.0 & 138.3 & 115.5 & 143.6 & 167.8 \\
\hline 1916:2 & 164.2 & 138.2 & 115.4 & 144.6 & 164.4 \\
\hline 1916:3 & 162.1 & 135.4 & 112.2 & 142.4 & 163.4 \\
\hline 1916:4 & 160.7 & 135.0 & 112.6 & 140.7 & 163.1 \\
\hline 1916:5 & 160.1 & 134.9 & 112.4 & 140.8 & 162.7 \\
\hline 1916:6 & 163.7 & 137.1 & 114.8 & 141.5 & 167.6 \\
\hline 1916:7 & 164.3 & 137.1 & 115.8 & 140.1 & 166.3 \\
\hline 1916:8 & 164.0 & 136.9 & 115.5 & 139.8 & 166.4 \\
\hline 1916:9 & 166.1 & 137.5 & 116.4 & 140.4 & 165.4 \\
\hline 1916:10 & 165.2 & 135.2 & 114.2 & 136.7 & 168.0 \\
\hline 1916:11 & 162.3 & 130.6 & 109.5 & 132.7 & 165.4 \\
\hline 1916:12 & 164.5 & 133.5 & 109.5 & 141.5 & 163.3 \\
\hline 1917:1 & 163.8 & 133.3 & 112.0 & 134.6 & 166.9 \\
\hline 1917:2 & 158.5 & 128.8 & 108.4 & 129.9 & 160.5 \\
\hline 1917:3 & 156.0 & 128.6 & 109.7 & 127.1 & 159.7 \\
\hline 1917:4 & 156.7 & 129.3 & 111.0 & 128.7 & 153.1 \\
\hline 1917:5 & 158.6 & 131.3 & 113.7 & 129.7 & 152.7 \\
\hline 1917:6 & 163.0 & 132.7 & 114.2 & 131.4 & 157.5 \\
\hline 1917:7 & 163.0 & 131.4 & 112.2 & 131.7 & 155.8 \\
\hline 1917:8 & 163.4 & 131.8 & 113.2 & 129.9 & 159.0 \\
\hline 1917:9 & 166.4 & 134.6 & 116.1 & 130.7 & 166.0 \\
\hline 1917:10 & 167.0 & 134.6 & 116.2 & 130.5 & 166.0 \\
\hline 1917:11 & 171.3 & 140.5 & 123.7 & 129.2 & 181.0 \\
\hline 1917:12 & 174.8 & 140.8 & 122.4 & 130.3 & 188.0 \\
\hline 1918:1 & 178.6 & 143.8 & 123.9 & 135.0 & 192.0 \\
\hline 1918:2 & 180.8 & 145.4 & 126.0 & 135.8 & 193.1 \\
\hline
\end{tabular}




\begin{tabular}{|c|c|c|c|c|c|}
\hline 1918:3 & 182.9 & 143.4 & 127.2 & 129.9 & 189.7 \\
\hline 1918:4 & 179.7 & 139.5 & 122.0 & 127.7 & 188.5 \\
\hline 1918:5 & 180.8 & 141.2 & 122.1 & 129.7 & 195.5 \\
\hline 1918:6 & 186.3 & 145.6 & 125.9 & 134.5 & 199.3 \\
\hline 1918:7 & 191.0 & 148.7 & 128.3 & 139.1 & 198.4 \\
\hline 1918:8 & 197.9 & 153.5 & 135.3 & 138.9 & 206.1 \\
\hline 1918:9 & 201.7 & 159.1 & 142.6 & 141.5 & 210.9 \\
\hline 1918:10 & 201.6 & 157.9 & 140.3 & 142.2 & 208.3 \\
\hline 1918:11 & 203.4 & 159.7 & 141.4 & 143.8 & 213.7 \\
\hline 1918:12 & 205.0 & 161.2 & 142.7 & 146.8 & 209.9 \\
\hline 1919:1 & 209.2 & 163.3 & 144.7 & 147.6 & 215.4 \\
\hline 1919:2 & 206.8 & 162.0 & 145.9 & 143.9 & 210.6 \\
\hline 1919:3 & 203.9 & 159.2 & 146.2 & 136.1 & 210.7 \\
\hline 1919:4 & 202.6 & 157.6 & 146.3 & 132.5 & 208.9 \\
\hline 1919:5 & 205.2 & 159.1 & 147.0 & 135.0 & 209.9 \\
\hline 1919:6 & 208.0 & 160.6 & 149.6 & 132.7 & 218.2 \\
\hline 1919:7 & 207.9 & 160.6 & 149.6 & 132.7 & 218.2 \\
\hline 1919:8 & 200.6 & 155.7 & 145.5 & 129.6 & 206.0 \\
\hline 1919:9 & 202.1 & 153.9 & 143.4 & 128.3 & 204.5 \\
\hline 1919:10 & 205.3 & 155.4 & 143.7 & 129.9 & 211.5 \\
\hline 1919:11 & 205.5 & 152.8 & 140.6 & 128.1 & 210.2 \\
\hline 1919:12 & 204.2 & 150.6 & 138.1 & 126.3 & 209.1 \\
\hline 1920:1 & 203.4 & 150.8 & 139.4 & 125.6 & 207.2 \\
\hline 1920:2 & 198.4 & 148.4 & 138.2 & 123.6 & 196.7 \\
\hline $1920: 3$ & 194.1 & 142.9 & 134.5 & 112.8 & 205.3 \\
\hline 1920:4 & 188.6 & 136.6 & 127.1 & 108.1 & 202.8 \\
\hline 1920:5 & 185.9 & 133.3 & 125.0 & 102.4 & 204.7 \\
\hline 1920:6 & 178.2 & 128.3 & 121.1 & 97.7 & 196.2 \\
\hline 1920:7 & 173.8 & 123.5 & 118.8 & 90.9 & 187.9 \\
\hline 1920:8 & 170.5 & 123.6 & 120.0 & 90.2 & 184.6 \\
\hline 1920:9 & 167.9 & 121.6 & 118.7 & 88.2 & 179.7 \\
\hline 1920:10 & 165.9 & 119.4 & 119.2 & 81.1 & 182.1 \\
\hline 1920:11 & 165.5 & 119.3 & 117.4 & 83.9 & 179.1 \\
\hline 1920:12 & 166.6 & 122.0 & 118.9 & 88.3 & 179.1 \\
\hline 1921:1 & 164.5 & 119.4 & 117.5 & 84.4 & 176.4 \\
\hline 1921:2 & 160.9 & 118.4 & 119.0 & 80.4 & 173.1 \\
\hline 1921:3 & 159.5 & 118.7 & 120.0 & 78.9 & 176.1 \\
\hline 1921:4 & 156.4 & 120.2 & 120.6 & 82.1 & 173.5 \\
\hline 1921:5 & 159.3 & 124.4 & 125.3 & 85.8 & 172.5 \\
\hline 1921:6 & 159.6 & 125.4 & 127.0 & 85.4 & 174.4 \\
\hline 1921:7 & 165.8 & 133.2 & 130.9 & 96.8 & 181.1 \\
\hline 1921:8 & 164.9 & 132.1 & 129.9 & 95.9 & 180.1 \\
\hline 1921:9 & 166.7 & 132.9 & 130.8 & 94.3 & 189.4 \\
\hline 1921:10 & 161.3 & 125.4 & 124.6 & 86.0 & 183.0 \\
\hline 1921:11 & 161.0 & 129.4 & 128.7 & 91.6 & 174.1 \\
\hline 1921:12 & 168.1 & 134.0 & 129.0 & 100.0 & 183.8 \\
\hline
\end{tabular}




\begin{tabular}{|c|c|c|c|c|c|}
\hline 1922:1 & 169.1 & 139.8 & 136.4 & 100.1 & 197.4 \\
\hline 1922:2 & 166.1 & 136.2 & 131.8 & 97.7 & 197.7 \\
\hline 1922:3 & 170.4 & 139.9 & 137.5 & 97.1 & 203.0 \\
\hline $1922: 4$ & 173.9 & 146.4 & 144.0 & 102.2 & 209.7 \\
\hline 1922:5 & 178.6 & 149.3 & 144.0 & 108.1 & 213.7 \\
\hline 1922:6 & 178.1 & 146.5 & 142.4 & 105.4 & 205.7 \\
\hline 1922:7 & 176.9 & 144.1 & 141.8 & 99.0 & 210.7 \\
\hline 1922:8 & 177.7 & 145.3 & 143.8 & 99.0 & 210.3 \\
\hline 1922:9 & 173.2 & 142.9 & 142.8 & 94.9 & 208.4 \\
\hline 1922:10 & 178.8 & 150.5 & 146.0 & 105.6 & 220.1 \\
\hline 1922:11 & 180.8 & 150.0 & 147.4 & 101.9 & 221.0 \\
\hline 1922:12 & 181.8 & 150.1 & 149.2 & 99.8 & 220.0 \\
\hline 1923:1 & 176.9 & 143.4 & 145.0 & 89.0 & 218.1 \\
\hline 1923:2 & 188.9 & 153.5 & 146.5 & 108.5 & 222.5 \\
\hline 1923:3 & 185.9 & 152.3 & 150.8 & 98.7 & 218.8 \\
\hline 1923:4 & 193.9 & 162.3 & 154.8 & 114.3 & 228.0 \\
\hline 1923:5 & 202.1 & 168.9 & 161.7 & 117.0 & 241.3 \\
\hline 1923:6 & 200.6 & 170.3 & 161.7 & 118.7 & 249.3 \\
\hline 1923:7 & 200.0 & 168.6 & 162.6 & 113.8 & 245.3 \\
\hline 1923:8 & 199.0 & 166.4 & 160.8 & 111.1 & 244.8 \\
\hline 1923:9 & 199.0 & 167.6 & 160.2 & 115.3 & 243.0 \\
\hline 1923:10 & 196.1 & 165.6 & 159.4 & 112.4 & 239.0 \\
\hline 1923:11 & 194.1 & 163.9 & 158.6 & 109.6 & 238.0 \\
\hline 1923:12 & 194.2 & 163.2 & 159.4 & 108.4 & 230.4 \\
\hline 1924:1 & 198.3 & 172.1 & 166.8 & 116.4 & 241.4 \\
\hline 1924:2 & 195.8 & 171.7 & 168.4 & 114.8 & 233.9 \\
\hline 1924:3 & 194.2 & 168.7 & 164.3 & 114.1 & 231.5 \\
\hline 1924:4 & 192.1 & 168.1 & 166.4 & 110.2 & 226.0 \\
\hline 1924:5 & 189.8 & 168.0 & 167.3 & 109.4 & 223.3 \\
\hline 1924:6 & 190.2 & 168.2 & 168.7 & 107.6 & 223.6 \\
\hline 1924:7 & 191.0 & 168.7 & 168.7 & 108.8 & 223.2 \\
\hline $1924: 8$ & 188.1 & 167.0 & 168.7 & 104.4 & 223.3 \\
\hline 1924:9 & 191.3 & 166.2 & 168.6 & 103.3 & 220.6 \\
\hline 1924:10 & 189.8 & 165.9 & 171.1 & 98.3 & 221.2 \\
\hline 1924:11 & 187.3 & 164.1 & 170.2 & 96.3 & 216.6 \\
\hline 1924:12 & 189.8 & 165.0 & 171.7 & 94.3 & 223.5 \\
\hline 1925:1 & 191.4 & 166.8 & 175.1 & 91.6 & 232.6 \\
\hline 1925:2 & 194.6 & 169.4 & 179.4 & 90.5 & 236.1 \\
\hline $1925: 3$ & 194.1 & 167.9 & 181.6 & 83.2 & 234.2 \\
\hline $1925: 4$ & 193.3 & 164.0 & 176.3 & 81.7 & 234.6 \\
\hline 1925:5 & 189.3 & 158.5 & 174.3 & 70.7 & 231.9 \\
\hline 1925:6 & 186.7 & 156.9 & 177.4 & 61.5 & 228.2 \\
\hline 1925:7 & 185.0 & 155.2 & 175.6 & 60.4 & 226.7 \\
\hline $1925: 8$ & 177.1 & 149.8 & 172.7 & 51.9 & 221.9 \\
\hline $1925: 9$ & 169.8 & 147.5 & 173.1 & 44.5 & 221.0 \\
\hline $1925: 10$ & 175.1 & 149.4 & 172.2 & 49.8 & 223.0 \\
\hline
\end{tabular}




\begin{tabular}{|c|c|c|c|c|c|}
\hline $1925: 11$ & 176.0 & 148.9 & 173.0 & 45.2 & 229.7 \\
\hline 1925:12 & 178.3 & 154.5 & 175.9 & 54.4 & 226.2 \\
\hline 1926:1 & 176.9 & 152.2 & 173.8 & 51.3 & 227.8 \\
\hline 1926:2 & 174.3 & 150.4 & 172.3 & 49.6 & 225.7 \\
\hline 1926:3 & 179.3 & 153.6 & 173.7 & 54.8 & 226.9 \\
\hline 1926:4 & 183.6 & 153.0 & 172.7 & 53.1 & 235.0 \\
\hline 1926:5 & 187.8 & 156.5 & 174.6 & 55.8 & 246.8 \\
\hline 1926:6 & 185.7 & 156.2 & 174.2 & 56.6 & 242.9 \\
\hline 1926:7 & 182.9 & 155.9 & 175.4 & 54.0 & 241.1 \\
\hline $1926: 8$ & 179.2 & 156.3 & 176.6 & 51.2 & 249.0 \\
\hline 1926:9 & 177.8 & 155.5 & 176.5 & 48.5 & 252.7 \\
\hline $1926: 10$ & 178.4 & 155.9 & 177.8 & 48.0 & 249.3 \\
\hline 1926:11 & 177.3 & 154.9 & 177.1 & 47.1 & 247.2 \\
\hline 1926:12 & 176.4 & 153.8 & 176.6 & 45.5 & 245.3 \\
\hline 1927:1 & 177.9 & 153.1 & 172.8 & 50.2 & 241.8 \\
\hline 1927:2 & 178.5 & 156.0 & 174.6 & 54.1 & 242.5 \\
\hline 1927:3 & 175.9 & 157.1 & 174.0 & 58.9 & 234.8 \\
\hline 1927:4 & 176.8 & 157.7 & 173.8 & 60.8 & 235.1 \\
\hline 1927:5 & 177.6 & 161.3 & 178.9 & 61.6 & 234.8 \\
\hline 1927:6 & 179.2 & 160.6 & 177.0 & 62.6 & 236.1 \\
\hline 1927:7 & 177.0 & 158.5 & 177.3 & 56.2 & 236.0 \\
\hline $1927: 8$ & 174.2 & 156.4 & 174.5 & 56.6 & 231.3 \\
\hline 1927:9 & 174.0 & 157.7 & 176.8 & 56.4 & 230.5 \\
\hline $1927: 10$ & 174.4 & 157.5 & 175.6 & 57.8 & 229.8 \\
\hline 1927:11 & 173.7 & 158.5 & 178.3 & 54.5 & 234.4 \\
\hline $1927: 12$ & 177.1 & 158.8 & 177.0 & 55.5 & 243.2 \\
\hline 1928:1 & 182.2 & 162.7 & 180.6 & 57.0 & 253.9 \\
\hline 1928:2 & 183.6 & 164.2 & 182.8 & 57.0 & 254.7 \\
\hline 1928:3 & 182.2 & 165.8 & 185.9 & 56.4 & 252.6 \\
\hline 1928:4 & 182.5 & 168.4 & 190.6 & 56.2 & 247.2 \\
\hline 1928:5 & 186.9 & 170.5 & 194.4 & 53.9 & 251.4 \\
\hline 1928:6 & 186.7 & 171.5 & 195.8 & 54.7 & 249.3 \\
\hline 1928:7 & 183.7 & 169.4 & 194.3 & 52.4 & 246.0 \\
\hline 1928:8 & 178.4 & 165.9 & 191.4 & 47.9 & 247.4 \\
\hline 1928:9 & 180.8 & 168.4 & 195.0 & 46.8 & 253.2 \\
\hline 1928:10 & 183.9 & 170.7 & 198.8 & 46.6 & 251.5 \\
\hline 1928:11 & 185.1 & 171.9 & 199.4 & 47.7 & 256.0 \\
\hline 1928:12 & 184.0 & 172.3 & 199.8 & 48.1 & 256.0 \\
\hline 1929:1 & 190.7 & 178.0 & 204.7 & 52.9 & 262.1 \\
\hline 1929:2 & 188.4 & 174.5 & 199.7 & 52.9 & 259.8 \\
\hline 1929:3 & 184.8 & 172.7 & 199.8 & 47.4 & 260.2 \\
\hline 1929:4 & 186.1 & 174.1 & 201.1 & 49.4 & 257.3 \\
\hline 1929:5 & 187.1 & 176.2 & 204.8 & 48.6 & 255.4 \\
\hline 1929:6 & 188.1 & 177.1 & 206.9 & 47.2 & 255.8 \\
\hline 1929:7 & 194.2 & 181.0 & 202.3 & 61.1 & 258.4 \\
\hline 1929:8 & 191.2 & 177.9 & 198.6 & 60.3 & 255.7 \\
\hline
\end{tabular}




\begin{tabular}{llllll}
\hline $\mathbf{1 9 2 9 : 9}$ & 189.1 & 175.6 & 197.3 & 56.3 & 255.3 \\
\hline $\mathbf{1 9 2 9 : 1 0}$ & 188.4 & 177.5 & 197.9 & 60.7 & 253.6 \\
\hline $\mathbf{1 9 2 9 : 1 1}$ & 187.7 & 176.1 & 198.1 & 55.2 & 256.4 \\
$\mathbf{1 9 2 9 : 1 2}$ & 184.9 & 175.0 & 196.9 & 56.1 & 249.1 \\
\hline $\mathbf{1 9 3 0 : 1}$ & 187.8 & 175.3 & 195.5 & 57.5 & 257.7 \\
$\mathbf{1 9 3 0 : 2}$ & 187.7 & 174.7 & 195.4 & 54.8 & 261.4 \\
\hline $\mathbf{1 9 3 0 : 3}$ & 191.0 & 175.0 & 197.3 & 50.6 & 267.8 \\
$\mathbf{1 9 3 0 : 4}$ & 192.7 & 178.6 & 201.8 & 52.4 & 265.2 \\
\hline $\mathbf{1 9 3 0 : 5}$ & 198.2 & 182.7 & 203.7 & 58.6 & 269.0 \\
\hline $\mathbf{1 9 3 0 : 6}$ & 197.3 & 183.6 & 204.4 & 60.3 & 266.2 \\
\hline
\end{tabular}

